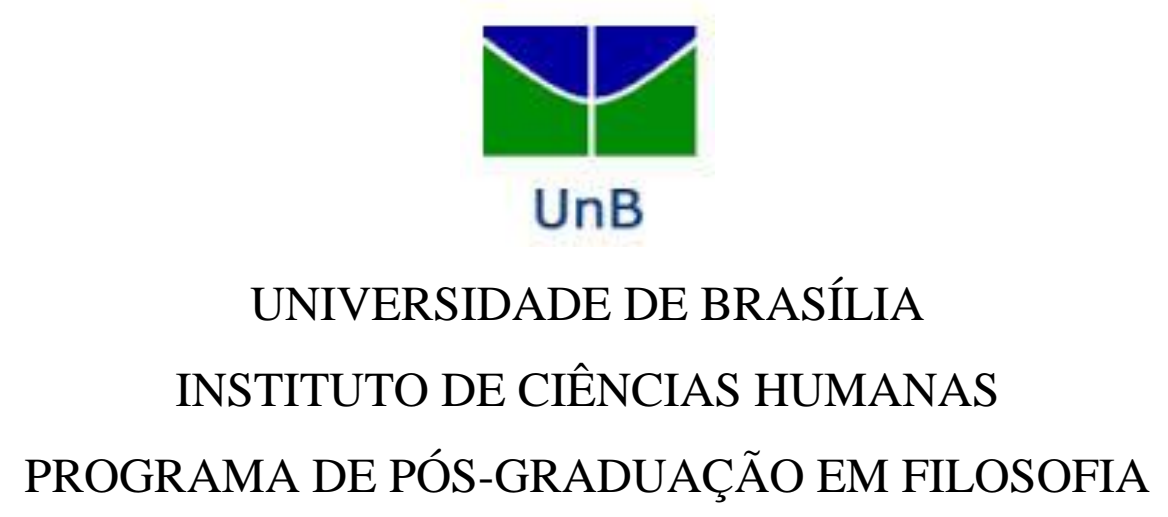

A NOÇÃO DE PESSOA DE HENRIQUE VAZ: UMA RESPOSTA À
NEGAÇÃO DA IDENTIDADE PESSOAL EM HUME

ALEXANDRE MADRUGA DA COSTA ARAÚJO

Brasília, junho de 2016 


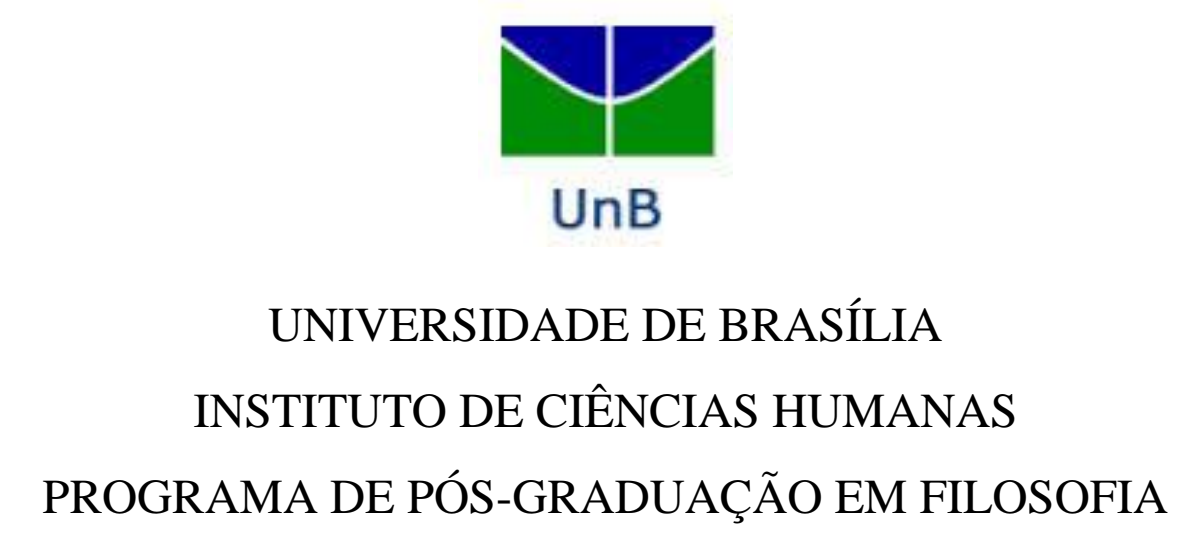

\title{
A NOÇÃO DE PESSOA DE HENRIQUE VAZ: UMA RESPOSTA À NEGAÇÃO DA IDENTIDADE PESSOAL EM HUME
}

\author{
ALEXANDRE MADRUGA DA COSTA ARAÚJO
}

Dissertação apresentada como requisito de conclusão do curso de mestrado em Filosofia da Universidade de Brasília.

Orientador: Agnaldo Cuoco Portugal.

Linha de Pesquisa: Filosofia da Religião.

Brasília, junho de 2016 


\section{AGRADECIMENTOS}

Agradeço a Deus, em primeiro lugar. E agradeço também aos meus pais, meu orientador e a todos os meus amigos que colaboraram comigo, direta ou indiretamente, na realização desta dissertação. 
“... não haveria em mim uma existência central, pessoal, autônoma? Seria eu um... des-almado? Então, o que se me fingia de um suposto $e u$, não seria mais que, sobre a persistência do animal, um pouco de herança, de soltos instintos, energia passional estranha, um entrecruzar-se de influências, e tudo o mais que na impermanência se indefine? (...) E, seria assim, com todos? Seríamos não muito mais que as crianças - o espírito do viver não passando de ímpetos espasmódicos, relampejados entre miragens: a esperança e a memória.”

(Guimarães Rosa. O Espelho). 


\section{RESUMO}

Esta dissertação visa apresentar uma crítica e uma alternativa ao problema da negação da identidade pessoal levantado por Hume, a partir de alguns elementos presentes na Antropologia Filosófica de Henrique Vaz, especialmente centrada no conceito de pessoa. Trata-se do confronto de duas propostas bem distintas: a primeira de cunho empirista e cético, e, a segunda, ancorada em categorias metafísicas.

Palavras-chave: pessoa - identidade pessoal - Hume - Henrique Vaz. 


\begin{abstract}
This dissertation aims to present a critique and an alternative to the problem of personal identity's negation raised by Hume, based on some elements present in Henrique Vaz's philosophical anthropology, which are specially focused on the concept of person. It is about the confrontation of two very different proposals: the first one, with a skeptical and empiricist hallmark and the second one, anchored in metaphysical categories.
\end{abstract}

Keywords: person - personal identity - Hume - Henrique Vaz 


\section{SUMÁRIO}

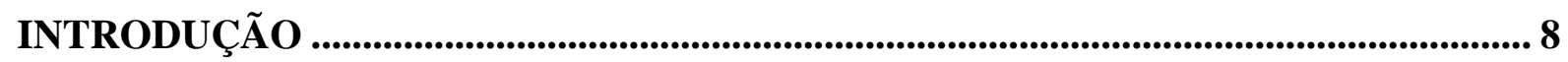

CAPÍTULO 1: A NEGAÇÃO DA IDENTIDAdE PESSOAL EM DAVID HUME....... 12

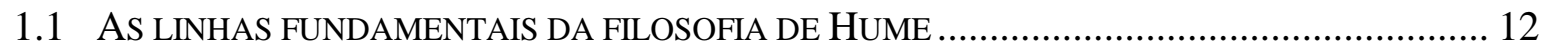

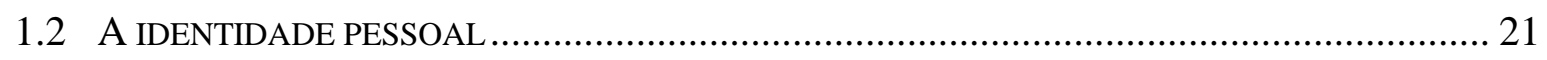

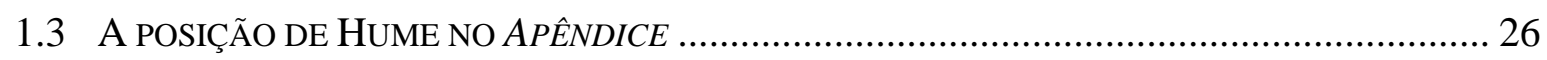

1.4 As CRÍTICAS DE ALGUNS COMENTAdORES DE HUME................................................. 27

\section{CAPÍTULO 2: A NOÇÃO DE PESSOA NA ANTROPOLOGIA FILOSÓFICA DE}

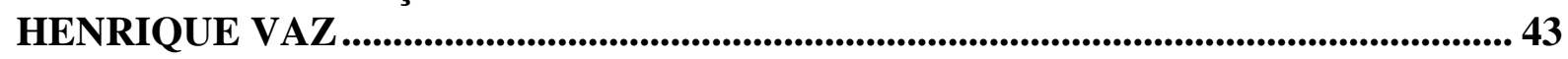

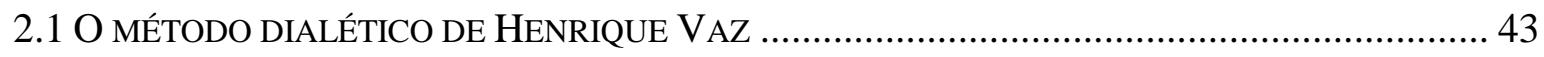

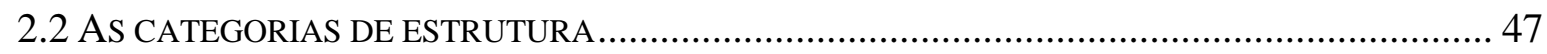

2.3 A TEORIA HILEMÓRFICA E A SUPERAÇÃO DO DUALISMO .............................................. 56

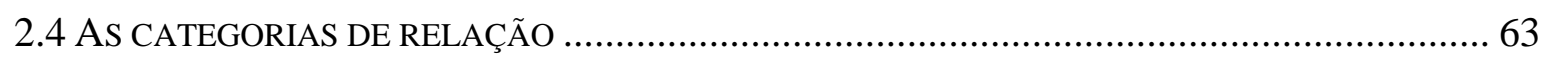

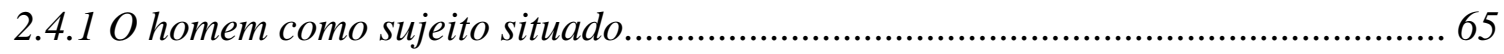

2.4.2 As relações de objetividade, de intersubjetividade e de transcendência................ 68

2.5 A UNIDADE NO SER HUMANO: A CATEGORIA DA REALIZAÇÃO ...................................... 73

2.6 A UNIDADE NO SER HUMANO: A CATEGORIA DA PESSOA .......................................... 76

CAPÍTULO 3: A RESPOSTA DE HENRIQUE VAZ À NEGAÇÃO HUMEANA DA

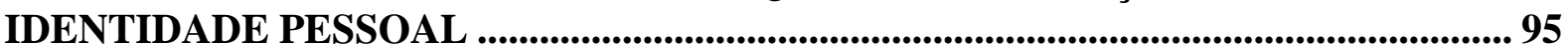

CONCLUSÃO

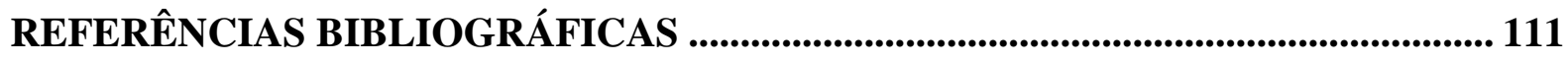




\section{Introdução}

Esta dissertação tem por objetivo geral apresentar duas concepções filosóficas distintas acerca da natureza do sujeito. De um lado, o empirismo cético de David Hume, que reduz o sujeito a um feixe de sucessivas impressões, desprovido de unidade e de permanência. De outro, a Antropologia Filosófica de Henrique Vaz, que, através do método dialético, apresenta a categoria filosófica da pessoa como vértice conceitual capaz de exprimir o sujeito como unidade dinâmica e síntese de oposição entre essência e existência.

A partir desse objetivo geral, o presente trabalho tem por objetivo específico buscar na obra Antropologia Filosófica de Henrique Vaz alguns elementos que possam servir como eventuais respostas críticas ao problema da negação da identidade pessoal levantado por Hume em seu Tratado da Natureza Humana.

Visando atingir o objetivo específico assinalado, a dissertação se estrutura em três capítulos. No primeiro, são apresentadas algumas linhas fundamentais da filosofia de Hume e as implicações em sua negação da identidade pessoal, seguidas de observações e críticas por parte de alguns de seus comentadores. No segundo capítulo, está exposta a visão de homem contida na Antropologia Filosófica de Henrique Vaz, acrescida de alguns paralelos com outras propostas contemporâneas ancoradas na mesma tradição metafísica seguida pelo filósofo brasileiro. Tais paralelos têm por finalidade tornar mais claros alguns aspectos do seu pensamento, além de revelarem seu vigor e atualidade. Por fim, no terceiro capítulo, analisamos, a partir do exposto nos capítulos precedentes, os elementos na Antropologia Filosófica de Henrique Vaz que permitem uma crítica e uma alternativa para o problema da negação da identidade pessoal levantado por Hume.

A questão do sujeito, sua natureza e o método correto para apreendê-lo intelectualmente foi e continua a ser sempre um dos temas principais da filosofia. Por isso mesmo, os mais vigorosos sistemas do pensamento filosófico moderno, bem como as tradições de maior prestígio e permanência na história da filosofia, sempre se detiveram sobre esse tópico, algumas vezes com abordagens bem distintas.

Entre todos os conceitos filosóficos que permeiam a temática do sujeito, o conceito de pessoa é, talvez, aquele que possui maior riqueza semântica. Embora a análise dos seus múltiplos sentidos nas diversas correntes filosóficas seja de grande valor especulativo, todavia não faz parte do escopo desta dissertação. 
No entanto, para maior compreensão do significado que a categoria filosófica da pessoa possui dentro da Antropologia Filosófica de Henrique Vaz, se faz necessário entender, ao menos em traços gerais, sua inserção na história da filosofia no século IV, bem como assinalar o sentido que assumiu no pensamento de Tomás de Aquino, à luz do qual o filósofo brasileiro apresentou sua proposta de concepção do homem como síntese metafísica de essência e existência (VAZ, 1992, p. 194).

Por essa razão, faremos agora, nesta introdução, uma breve e sintética exposição da origem filosófica do conceito de pessoa. Antes, porém, cumpre ressaltar que, apesar de não haver se detido explícita e diretamente sobre o conceito de pessoa, Hume utilizou diversas vezes a expressão identidade pessoal, com a finalidade de negar o caráter de unidade e de permanência de um suposto sujeito das impressões. Não deve causar estranheza esse silenciamento de Hume a respeito da noção de pessoa, uma vez que tal conceito possui uma forte conotação metafísica, perspectiva desprezada pelo filósofo escocês. Quanto ao tema do sujeito, em torno do qual orbita o conceito de pessoa, não há dúvidas de que foi objeto direto das especulações filosóficas de Hume, conforme se pode comprovar mais detidamente no primeiro capítulo.

A palavra "pessoa" da língua portuguesa deriva do substantivo latino persona, formado a partir da justaposição da preposição per ao substantivo sona - som. Sua origem etimológica remonta às máscaras do teatro romano, dotadas de um orifício na altura da boca que tornava a voz do ator mais vibrante e sonora. Inicialmente, a palavra persona assumiu uma série de significados em torno às representações teatrais, adquirindo basicamente quatro sentidos: i) o ato de representar pela voz um personagem; ii) a máscara; iii) o personagem interpretado; iv) o próprio ator, tendo este último sentido surgido posteriormente aos demais. Esse termo latino foi utilizado para traduzir a palavra grega prósopon- $\pi \rho$ ó $\omega \pi$ ov, máscara, a qual, por sua vez, provavelmente deriva da palavra etrusca $\varphi$ ersu - phersu (FAITANIN, 2006, p. 48 e 51$)$.

Num segundo momento, a palavra persona passou a designar um sentido político e jurídico, indicando algum papel social dotado de dignidade, tal como a expressão persona senatoris - pessoa de senador. Esse uso forense da palavra manteve a mesma linha de sentido do teatro, significando a dimensão exterior de um homem, e não o que ele é em si mesmo (HERVADA, 2008, p. 293).

Embora já tivesse sido utilizada num contexto filosófico por parte dos estóicos para designar o indivíduo humano dotado de dignidade social (FAITANIN, 2006, p. 52), 
podemos dizer que a categoria da pessoa somente nasceu para a filosofia a partir da reflexão em torno às disputas trinitárias e cristológicas da Antiguidade cristã. Com efeito, a patrística optou por utilizar as riquezas dos termos filosóficos gregos para estabelecer os dogmas trinitário e cristológico, exprimindo-os de uma forma inteligível, dentro de uma perspectiva de conciliação da razão com os mistérios revelados.

Os dogmas trinitário e cristológico são ainda hoje professados pelo magistério da Igreja Católica tal como foram formulados nos primeiros séculos do cristianismo. O dogma trinitário, definido no Primeiro Concílio de Nicéia no ano 325, consiste na crença de que Deus é uma trindade de pessoas na unidade de uma mesma essência divina. Não se trata de modalidades do ser divino, pois as pessoas se distinguem realmente entre si, embora também não se possa dizer que elas dividem a divindade em partes. Distinguem-se por sua relação de origem, isto é, a distinção reside na referência de umas às outras. O dogma cristológico, definido pelo Concílio de Calcedônia no ano 451, consiste na afirmação de que Jesus Cristo

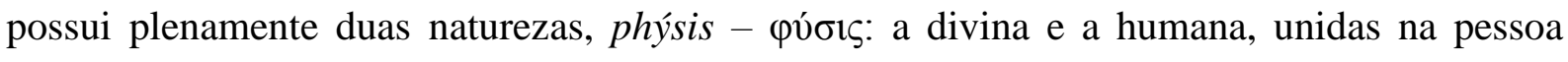

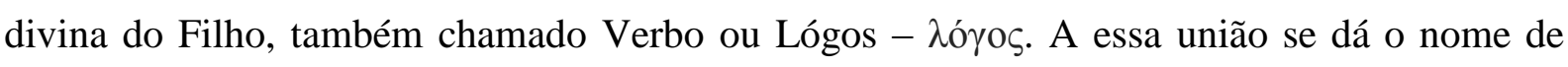
união hipostática.

Pois bem, nos dois dogmas acima, a patrística preferiu designar as pessoas divinas com a palavra grega hypóstasis - v́đóotăoıs, e não com a palavra prósopon, tendo em vista que esta poderia remeter ao sentido originário de aparência enganosa. Segundo Boécio, por hypóstasis se designava o ato de sustentar, a natureza real subsistente de algo indivídual, que serve de suporte para as qualidades e determinações acidentais (LOMBO, 2001, p. 95). Dessa forma, embora a palavra latina persona tenha como equivalência no grego dois significados distintos, prósopon e hypóstasis, em sua acepção teológica e também filosófica ela passou a se identificar com o segundo. Assim, pela evolução do uso do termo, hypóstasis deixou de significar qualquer substância em sua existência individual, para se referir apenas às substâncias individuais dotadas de natureza intelectual, designadas pela palavra latina persona (FAITANIN, 2006, p. 56). Não é outra a célebre definição de pessoa formulada por Boécio: rationalis naturae individua substantia - substância individual de natureza racional.

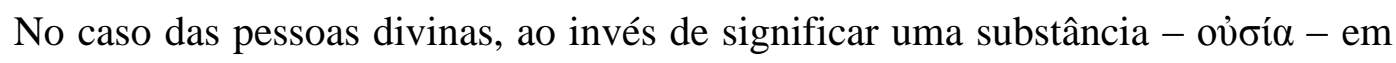
sua individualidade e racionalidade, hypóstasis significa uma relação subsistente (TOMÁS DE AQUINO, S. Theo., q. 29, a. 4). Dessa forma, o dogma trinitário fica a salvo de uma concepção politeísta na qual se afirmariam três substâncias ou naturezas subsistentes. 
Tomás de Aquino aceita a definição de Boécio, embora a entenda dentro de um sentido analógico mais amplo não tão preso à literalidade da definição (LOMBO, 2001, p. 137-138), aplicável tanto às pessoas divinas quanto às pessoas humanas. Por isso mesmo, embora defenda e explique a definição de Boécio, define a pessoa com outra fórmula: subsistens in rationali natura - o que subsiste numa natureza racional (VAZ, 1992, p. 225). Três são, portanto, as coordenadas da noção de pessoa: subsistir, ser distinto e ser intelectual. A subsistência significa a integridade e o receber o ser em si, que é próprio da substância. Logo, existir e ter uma essência completa faz parte da noção de pessoa, razão pela qual Tomás de Aquino considera que a alma humana separada do corpo após a morte não é pessoa. O ser distinto significa a incomunicabilidade, na qual a distinção atinge um grau ainda mais intenso do que a mera individualidade causada pela matéria. A individualidade dos seres pessoais supera o mero ser indiviso em si mesmo e ser diverso dos demais, próprio de qualquer indivíduo de determinada espécie. Trata-se de uma individualidade que é intimidade, na medida em que é possuída pelo próprio sujeito e construída a partir das suas próprias ações. A natureza intelectual significa que essa hypóstasis pode realizar ações que transcendem o âmbito do material, permitindo a esses indivíduos serem donos dos seus próprios atos, o que se manifesta na liberdade, por meio da qual a imagem de Deus nesses seres resta mais evidente (LOMBO, 2001, p. 361-364).

Ao se referir especificamente às pessoas divinas, Tomás de Aquino também sugere a definição de Ricardo de S. Vitor: divinae naturae incomunicabilis existencia existência incomunicável da natureza divina (S. Theo., q. 29, a. 3).

$\mathrm{Na}$ modernidade, aparecem novas formas de conceber a pessoa, muito distintas daquilo que se pensou na filosofia cristã. Segundo Henrique Vaz, apesar de muito variadas, as propostas modernas de se pensar o sujeito possuem como característica comum um movimento de imanentização e ruptura da comunidade analógica com o Absoluto (VAZ, 1992, p. 221). Nesse processo, as noções de consciência e subjetividade adquiriram mais força, ressaltando na noção de pessoa os aspectos mais propriamente psicológicos do que ontológicos.

Estabelecida esta breve contextualização histórica acerca da gênese do conceito de pessoa na filosofia, passemos a analisar o problema da negação da identidade pessoal levantado por David Hume. 


\section{Capítulo 1: A negação da identidade pessoal em David Hume}

Em sua obra Tratado da Natureza Humana o filósofo escocês David Hume se propõe estudar a fundo a natureza humana, centro capital de todas as ciências (lógica, moral, política, etc.) e seu único fundamento sólido. Dessa forma, como condição imprescindível para se fazer ciência, torna-se necessário conhecer o homem em seus processos psicológicos e comportamentais. Esse conhecimento deve partir da experiência e da observação (HUME, 2009, p. 22), tal como nas ciências da natureza.

Para entendermos melhor a crítica à noção de identidade pessoal feita por Hume na mencionada obra, passemos a examinar as grandes linhas da sua filosofia, que começa a partir da análise dos processos mentais e termina em seus consequentes desdobramentos políticos e morais.

\subsection{As linhas fundamentais da filosofia de Hume}

Partindo de pressupostos empiristas, Hume estabelece que os conteúdos da mente são derivados da experiência e constituem as percepções, as quais, por sua vez, podem ser de duas espécies: impressões ou ideias. As primeiras são mais fortes e vivazes do que as segundas (HUME, 2009, p. 43). Nas impressões estão incluídas as sensações, paixões e emoções. Já as ideias, são construídas a partir das impressões, apresentando-se como imagens destas (HUME, 2009, p. 25), o que torna algumas vezes difícil diferenciar uma ideia de uma impressão, conforme admite o próprio Hume (2009, p. 26). As ideias são produzidas a partir das impressões, razão pela qual o pensamento mais vívido, representado por uma ideia, é inferior à impressão mais fraca, ou seja, no processo de conhecimento, a sensação possui um nível epistemológico superior ao pensamento, o que torna a filosofia de Hume uma representante do empirismo sensualista.

Hume faz uma distinção entre percepções (impressões e ideias) simples e complexas. Uma ideia simples sempre corresponde a uma impressão simples e vice-versa (HUME, 2009, p. 27). As ideias e impressões simples são aquelas que não admitem nenhuma distinção ou 
separação. As ideias e impressões complexas são produzidas a partir das simples, podendo ser distinguidas em partes (HUME, 2009, p. 26).

Outra distinção feita é aquela entre as ideias primárias e secundárias. As secundárias seriam aquelas derivadas das primárias, da mesma forma que as ideias primárias são imagens das impressões (HUME, 2009, p. 31). De modo análogo às ideias primárias e secundárias, existem as impressões de sensação e de reflexão, sendo que as primeiras derivam da alma e as segundas das nossas ideias. Como exemplo de uma impressão reflexiva, podemos apontar a sensação de frio provocada pela ideia de frio, a qual, por sua vez, derivou originariamente de uma primeira impressão de frio (HUME, 2009, p. 32).

As distinções assinaladas por Hume não são fruto de um mero passatempo acadêmico, pois possuem importância na crítica às ideias de substância e causalidade, as quais não passariam de ficções mentais, destituídas de realidade em si mesmas, na medida em que tais ideias não procedem de uma impressão específica.

A memória e a imaginação apresentam um papel importante na filosofia de Hume. Diferenciam-se pelo grau de vivacidade: a memória é mais vivaz, reproduz algo que seria um intermediário entre impressões e ideias, enquanto a imaginação reproduz ideias. A memória, além das ideias simples, conserva sua ordem e posição, enquanto a imaginação limita-se a unir e separar ideias, geralmente segundo princípios gerais de associação. Na memória há uma conexão inseparável entre as ideias, enquanto na imaginação há mais liberdade de criação, na medida em que não se restringe à mesma ordem e forma das impressões originais (HUME, 2009, p. 33). Há na imaginação um princípio inato, uma força suave da natureza, que lhe move a combinar (associar) determinados tipos de ideias. Com efeito, a existência desse princípio seria constatada pelo fato de que as mesmas ideias simples costumam se associar de maneira regular nas mesmas ideias complexas (HUME, 2009, p. 34).

A associação de ideias na imaginação dá-se em dois sentidos de relação. No primeiro, típico da linguagem corrente, a relação entre duas ideias dá-se na forma natural de associação, em três modalidades: i) semelhança; ii) contiguidade espaço-temporal; iii) causa e efeito (HUME, 2009, p. 35). No segundo sentido de relação, um pouco mais abrangente que o primeiro e geralmente usado pelos filósofos, há uma espécie de arbítrio (liberdade criativa) na união entre duas ideias, na forma de sete modalidades de relação: semelhança, identidade, relações espaço-temporais, número, graus de qualidade, contrariedade e relação de causa e efeito (HUME, 2009, p. 38-39). 
A partir desses princípios, Hume negará: a existência de ideias universais na mente; a ideia de substância e a possibilidade de se demonstrar a existência da relação de causa e efeito fora da mente do sujeito. Passemos a analisar brevemente cada uma dessas negações, que fazem de Hume um pensador cético e empirista.

A negação da existência de ideias universais na mente está ancorada no sistema de impressões e ideias estabelecido por Hume, já que as ideias são sempre imagens de impressões determinadas. Por ser mera cópia de uma impressão particular, a ideia não poderia jamais ser universal, até porque, tudo o que nossa observação e experiência nos apresentam são impressões individuais, particulares e concretas.

Mesmo as ideias mais abstratas são sempre particulares e individuais. Às vezes, a essas ideias são acrescidos certos termos de significação mais extensa, que permitem que determinada ideia recorde outra semelhante a ela. Todavia, não se trataria de uma ideia única e igualmente aplicável a diferentes percepções, mas apenas a aplicação por extensão e semelhança a entidades por si mesmas distintas (HUME, 2009, p. 41).

As ideias mais abstratas que parecem abranger um grande número de indivíduos com quantidades e qualidades diferentes entre si (por exemplo, o conceito de homem) são sempre pensadas pela imaginação, sem prescindir das qualidades e quantidades. Com efeito, para Hume “... a mente não pode formar nenhuma noção de quantidade ou qualidade sem formar uma noção precisa dos graus de cada uma" (HUME, 2009, p. 42). Assim, sempre que pensamos numa linha, por exemplo, pensamos numa imagem particular de linha, com determinada extensão (HUME, 2009, p. 43). Dessa forma, o filósofo escocês parece negar a possibilidade de haver um conceito puramente inteligível para além da sua representação sensível por meio de uma imagem. Nessas condições, como nossa imaginação sempre representa os conceitos que pensamos associando-os a uma imagem específica, Hume parece concluir que tais conceitos se limitam às imagens sensíveis aos quais são associados pela imaginação.

Seguindo essa linha de pensamento, Hume afirma que algumas ideias particulares possuem aplicação a diversos objetos, através de uma ampliação da significação destas ideias por meio do hábito, ou seja, embora as ideias sejam sempre particulares em si mesmas, muitas vezes seu uso é geral, aplicando-se a mais de um objeto particular:

Tal aplicação das ideias para além de sua natureza procede do fato de que nós reunimos todos os seus graus possíveis de quantidade e de qualidade, de uma maneira que, embora imperfeita, é capaz de atender aos propósitos da vida (...). 
Quando encontramos uma semelhança entre diversos objetos que se apresentam a nós com frequência, aplicamos a todos eles o mesmo nome, não obstante as diferenças que possamos observar em seus graus de quantidade e qualidade, e não obstante quaisquer outras diferenças que possam surgir entre eles [...] A palavra desperta uma ideia individual, juntamente com um certo costume; e esse costume produz qualquer outra ideia individual que se faça necessária [...]

Tal é, portanto, a natureza de nossas ideias abstratas e de nossos termos gerais; e é dessa maneira que resolvemos o paradoxo anterior, a saber, que algumas ideias são particulares em sua natureza, mas gerais pelo que representam. Uma ideia particular se torna geral quando a vinculamos a um termo geral - isto é, a um termo que, por uma conjunção habitual, relaciona-se com muitas outras ideias particulares, evocando-as prontamente na imaginação. (HUME, 2009, p. 44-46).

Explicar o modo concreto como é feita a indução de uma ideia mais genérica a partir de outras ideias particulares seria descrever em todos os detalhes o modo de funcionamento do hábito, o que não é possível, senão indiretamente, por meio de analogias, conforme opinião de Hume (2009, p. 46). Para ilustrar esse tipo de analogia, Hume lança mão de um falso juízo geométrico (2009, p. 45), segundo o qual um triângulo é uma figura geométrica cujos três lados e três angulos internos são iguais entre si. O erro é facilmente perceptível, sem que seja necessário recorrer diretamente a um conceito universal. A percepção da falsidade do juízo e sua inaplicação a uma série de exemplos concretos (no exemplo mencionado, os triângulos escalenos e isósceles escapariam àquela definição de triângulo e isso seria facilmente perceptível) se daria por meio da misteriosa e constante ação do hábito em nossa mente. Outra manifestação dessa misteriosa atuação do instinto mental (hábito) constata-se na capacidade que a mente tem de, ao vislumbrar uma ideia complexa, identificar termos aos quais ela não se aplica, mesmo desconhecendo algumas das ideias simples que integram essa ideia complexa. Exemplo disso seria a utilização da palavra 'conquista' (ideia complexa) numa aplicação equivocada. Graças à atuação do hábito, essa má aplicação seria imediatamente reconhecida, ainda que não se conhecessem todas as ideias simples que integram a ideia de 'conquista', conforme palavras de Hume:

\footnotetext{
Observe-se, entretanto que, apesar dessa imperfeição, podemos evitar dizer absurdos acerca desses temas, e somos capazes de perceber qualquer incompatibilidade que haja entre as ideias, tão bem como se as compreendêssemos inteiramente. Assim, se, em vez de dizer que na guerra os mais fracos sempre recorrem à negociação, dissermos que eles sempre recorrem à conquista, o costume que adquirimos de atribuir certas relações às ideias, por continuar acompanhando essas palavras, fará com que percebamos imediatamente o absurdo dessa proposição... (HUME, 2009, p. 47).
}

Antes mesmo de negar a existência de ideias universais na mente, Hume nega a ideia de substância, pois a mesma não derivaria de nenhuma impressão particular, em 
qualquer de suas três formas: sensação, paixão e emoção. Logo, a ideia de substância não seria mais do que um aglomerado de ideias simples associadas pela imaginação, que se relacionam mutuamente por contiguidade espaço-temporal (HUME, 2009, p. 40). Visando demonstrar que a pretensa ideia de substância não passaria de um algomerado de ideias simples unificadas pela imaginação, Hume argumenta que a inclusão de uma qualidade posteriormente conhecida e atribuída à determinada substância, não contrariaria a ideia original daquela substância, apenas acrescentando uma ideia nova ao princípio de união a que se fazia referência originalmente:

\begin{abstract}
O resultado disso é que, sempre que descobrimos uma nova qualidade simples que tenha a mesma conexão com o restante, imediatamente a incluímos entre as outras, ainda que ela não tenha feito parte da nossa primeira concepção da substância em questão. Assim, por exemplo, a nossa ideia de ouro pode, a princípio, ser a de uma cor amarela, de peso, de maleabilidade e de fusibilidade; mas com a descoberta de sua solubilidade em água régia, acrescentamos esta última àquelas qualidades, e supomos que pertence à substância tanto como se sua ideia houvesse, desde o início, feito parte da ideia composta. (HUME, 2009, p. 40-41).
\end{abstract}

Negados os conceitos universais e a ideia de substância, Hume passa a negar a possibilidade da demonstração da existência das relações de causa e efeito na realidade.

Como toda ideia, precisamos investigar primeiramente de qual impressão advém a ideia de causa. Segundo Hume, a ideia de causa não provém de uma qualidade das coisas, mas sim de uma relação (2009, p. 103). Quanto ao tipo de relação, há dois elementos que, a princípio, parecem sempre compor a noção de causa: a contiguidade espacial e a sucessão temporal. Todavia, isso ainda não é o bastante, pois há objetos que são contíguos e um anterior ao outro, sem que atribuamos a eles a noção de causa e efeito. É indispensável que haja uma conexão necessária entre os objetos relacionados (HUME, 2009, p. 105). Portanto, nessa temática da relação de causa e efeito, é forçoso determinar de que tipo de impressão deriva a mencionada conexão necessária.

Segundo Hume, a conexão necessária não advém de alguma impressão particular. O que ocorre é que, por hábito, a partir da observação de alguns casos em que há uma conjunção constante de sucessão temporal e contiguidade espacial, inclinamo-nos psicologicamente a inferir uma conexão necessária entre dois objetos. Em outras palavras, não há como demonstrar de modo intuitivo ou empírico a relação de causalidade entre dois objetos. 
Intuitivamente não se pode comprovar a relação de causa e efeito entre dois objetos, pois a ideia de cada coisa pode ser pensada distinta e separadamente de seus efeitos. Hume recorre a uma suposta ligação que fazemos naturalmente: atribuímos ao objeto chama a sensação de calor, baseados, sobretudo, na experiência e observação. Ocorre que, ao menos no campo da intuição, podemos pensar separadamente na ideia de chama, sem recordar a sensação de calor e vice-versa. Portanto, da essência de um não implica a necessidade lógica da existência do outro (HUME, 2009, p. 116).

O mesmo raciocínio aplica para criticar o pensamento que atribui a necessidade de algo que começou a existir tenha por causa outro já existente. Hume diz que essa afirmação não poderia ser provada, pois a impossibilidade da sua negação: "algo não pode vir do nada", também não pode ser comprovada:

\begin{abstract}
Nunca poderíamos demonstrar a necessidade de uma causa para toda nova existência ou para toda nova modificação de existência sem mostrar, ao mesmo tempo, a impossibilidade de que alguma coisa comece a existir sem algum princípio produtivo [...] Ora [...] considerando que, como todas as ideias distintas são separáveis entre si, e como as ideias de causa e de efeito são evidentemente distintas, é fácil conceber que um objeto seja não existente neste momento e existente no momento seguinte, sem juntar a ele a ideia distinta de uma causa ou princípio produtivo. Portanto, a separação da ideia de uma causa da ideia de um começo de existência é claramente possível para a imaginação. Uma vez, portanto, que não implica contradição ou absurdo, a separação real desses objetos é possível, e por isso não pode ser refutada por nenhum raciocínio baseado nas meras ideias. E, sem isso, é impossível demonstrar a necessidade de uma causa. (HUME, 2009, p. 107-108).
\end{abstract}

De modo semelhante, Hume parece também entender como uma petição de princípio a afirmação de que algo não pode ter por causa o nada, pois o nada não pode ser causa de coisa alguma (2009, p. 109).

Embora Hume entenda que a atribuição de causa e efeito que fazemos às coisas provenha da experiência e da observação, a partir da conjunção constante de dois objetos, todavia afirma que essa atribuição é fruto do hábito mental e não da realidade das coisas observadas.

Hume passa a aplicar ao conhecimento empírico da causalidade o mesmo raciocínio que utilizara para negar o caráter intuitivo da ideia de causa. Com efeito, afirma que a uniformidade e regularidade observadas na natureza, que seriam os principais indicativos de uma existência real da causalidade, não são intuitivamente demonstráveis, pois seu contrário, a ideia de mudança, não é uma noção contraditória em si mesma (HUME, 2009, p. 118). Isto 
é, não há uma necessidade lógica da existência de uniformidade e regularidade na natureza, o que nos leva a concluir que tais atributos são frutos da nossa crença (HUME, 2009, p. 121).

Portanto, na opinião de Hume, mesmo a comprovada previsibilidade dos fenômenos empiricamente observáveis não pode ainda dar-nos certeza racional de uma conexão real e necessária entre dois objetos. Ou seja, essa conexão é projetada subjetivamente, através da associação de ideias na imaginação, para casos ainda não observados, a partir do que já foi observado e armazenado pela memória:

\footnotetext{
Assim, não apenas nossa razão nos falha na descoberta da conexão última entre causas e efeitos, mas, mesmo após a experiência ter-nos informado de sua conjunção constante, é impossível nos convencermos, pela razão, de que deveríamos estender essa experiência para além dos casos particulares que pudemos observar. Nós supomos, mas nunca conseguimos provar [...].

A razão jamais pode nos mostrar a conexão entre dois objetos, mesmo com a ajuda da experiência e da observação de sua conjunção constante em todos os casos passados. Portanto, quando a mente passa da ideia ou impressão de um objeto à ideia de outro objeto, ou seja, à crença neste, ela não está sendo determinada pela razão, mas por certos princípios que associam as ideias desses objetos, produzindo sua união na imaginação [...] A inferência, portanto, depende unicamente da união de ideias. (HUME, 2009, p. 120-121).
}

A partir das considerações acima mencionadas, Hume estabelece a seguinte definição de causa: "Uma causa é um objeto anterior e contíguo a outro, e unido a ele de tal forma que a ideia de um determina a mente a formar a ideia do outro, e a impressão de um a formar uma ideia mais vívida do outro.” (HUME, 2009, p. 203). Essa definição é aplicada por Hume somente para a ideia de causa eficiente, visto que ele rejeita outras espécies de causa (2009, p. 204).

Finalizando, em termos gerais, o pensamento de Hume a respeito dos processos causais, ressaltamos, mais uma vez que, apesar de apresentar-se cético quanto ao significado exato do que seria propriamente uma relação causal, bem como sobre a necessidade de se demonstrar sua existência na realidade, Hume não nega que o entendimento estabeleça relações causais a partir da conjunção constante de duas impressões contíguas espacialmente e sucessivas temporalmente, a partir de evidências passadas provenientes dos sentidos e assimiladas pela memória.

Nesse sentido, as relações de causa e efeito são essenciais para inferência de fatos a partir de outros fatos observados, conforme palavras de Hume: "É evidente que todos os raciocínios sobre questões de fato se fundam na relação de causa e efeito, e nunca poderemos 
inferir a existência de um objeto da existência de outro, a menos que eles estejam conectados, direta ou indiretamente." (HUME, 2009, p. 686-687).

Diante do que foi dito acima, Hume naturalmente conclui que os raciocínios sobre causa e efeito são objetos de suposição, tendo em vista que as inferências causais propriamente ditas não são decorrentes da razão, provindo antes do hábito mental adquirido a partir de experiências de percepções passadas (2009, p. 120).

Visando entender a origem dessa suposição, Hume passa a tecer algumas considerações a respeito da natureza da crença (2009, p. 125). Afirma que a crença na existência de um objeto não acrescenta à ideia daquele objeto um conceito novo, mas apenas lhe aumenta a força e a vividez, de modo a causar um assentimento na mente que conhece.

Com efeito, a ideia de existência acrescida à outra ideia prévia de um objeto não alteraria em nada a ideia deste mesmo objeto, mas apenas o modo em que a concebemos, conforme palavras de Hume:

\footnotetext{
Quando penso em Deus, quando penso nele como existente, e quando creio que ele existe, minha ideia dele não aumenta nem diminui. Mas, como é certo que há uma grande diferença entre a simples concepção da existência de um objeto e a crença nesta, e como tal diferença não repousa nas partes ou na composição da ideia que concebemos, segue-se que ela deve estar na maneira como a concebemos. (HUME, 2009, p. 123).
}

Essa alteração no modo em que se concebe uma ideia, causando na mente uma espécie de assentimento e permitindo que essa ideia seja sentida de maneira diferente, é o que difere a crença das fantasias produzidas pela imaginação (HUME, 2009, p. 126). Cumpre ressaltar, que são objeto de crença apenas questões causais e raciocínios de fato, restando excluídas as proposições provadas por intuição ou demonstração, tendo em vista que a negação destas seria algo absurdo e ininteligível (HUME, 2009, p. 124).

A intensidade e a vividez de uma ideia, que fazem nascer em nós a convicção de sua existência, são derivadas do costume (HUME, 2009, p. 146), que, por sua vez, é formado através da experiência e observação passados. Todavia, nem sempre essa transição é feita de maneira natural, pois muitas vezes a crença é induzida artificialmente através da educação (HUME, 2009, p. 146).

Dentre as diversas espécies de crenças, destacam-se duas fundamentais: a crença de que tudo tem uma causa e a crença na existência contínua e independente dos corpos. Quanto à primeira, já analisamos. Passemos a examinar brevemente a segunda. 
Para Hume, a existência ${ }^{1}$ contínua e independente dos corpos é objeto de crença, tendo em vista que não teríamos acesso ao mundo extramental em si mesmo, senão através de nossas próprias percepções. Com efeito, as ideias são redutíveis às impressões e estas são subjetivas, por pertencerem à mente perceptora. Portanto, nossas percepções são o horizonte final do nosso pensamento, a elas confinado, ou seja, a existência extramental dos objetos não pode ser percebida e comprovada pelos nossos sentidos, conforme argumenta Hume:

\begin{abstract}
Primeiro, que não é propriamente nosso corpo o que percebemos quando olhamos para nossos membros e partes corporais, mas certas impressões que entram pelos sentidos; de modo que a atribuição de uma existência real e corpórea a essas impressões, ou a seus objetos, é um ato da mente tão difícil de explicar quanto o que estamos agora examinando. Segundo, sons, sabores e aromas, embora costumem ser vistos pela mente como qualidades contínuas e independentes, não parecem ter nenhuma existência na extensão, e consequentemente não podem aparecer aos sentidos como situados fora do corpo... Terceiro, mesmo nossa visão não nos informa da distância ou exterioridade (por assim dizer) de maneira imediata e sem um certo raciocínio ou experiência, como reconhecem os filósofos mais razoáveis (2009, p. 224).
\end{abstract}

Nossa crença na existência contínua e independente dos corpos e nosso hábito de supor que existem cópias independentes das nossas impressões (na realidade) se deve à imaginação e não aos sentidos ou à razão (HUME, 2009, p. 226). Tal crença nasce de duas características presentes em algumas das nossas impressões: a constância e a coerência (HUME, 2009, p. 228), as quais nos permitem acreditar que existe uma realidade para além das nossas impressões. Como exemplo de constância presente nos objetos aos quais atribuímos existência contínua, Hume aponta para a experiência ordinária de observação de uma paisagem pela janela $(2009$, p. 227). Todas as distintas percepções que obtemos dessa paisagem parecem idênticas. Já como exemplo de coerência presente nos objetos aos quais atribuímos existência contínua, Hume destaca a percepção de que o fogo da sua lareira se consome de maneira regular em intervalos de tempo semelhantes (2009, p. 228). Essa dedução de que existe uma realidade independente das nossas percepções, nasce mais de um hábito psicológico do que da semelhança real (constância e coerência) das nossas impressões, tendo em vista que as impressões são sempre distintas. A ilusão provocada pelo hábito radica no fato de que a primeira impressão nos condiciona a pensar que as impressões que lhe sucedem são idênticas, ou seja, a constância e a coerência são mais uma tendência psicológica do que

\footnotetext{
${ }^{1}$ Hume (2009, p. 94) nega que haja uma impressão particular da qual derive a ideia de existência. Dessa forma, essa ideia não subsiste por si mesma, nem tem qualquer significado próprio que agregue valor a outras ideias.
} 
atributos de impressões supostamente semelhantes. Dessa forma, sendo as impressões sempre distintas, a aparência de interrupção de uma impressão depois recuperada é produzida pela memória. É a memória quem produz a aparente sensação de identidade entre duas impressões distintas, fazendo-nos crer, com uma ideia vivaz, na existência continuada e independente dos corpos (HUME, 2009, p. 232).

Diante do que dissemos acima, cabe ressaltar que Hume não nega a existência dos corpos, mas apenas apresenta-se cético quanto à prova de sua existência, seja pela via da razão, seja pela via dos sentidos (2009, p. 220).

Ante o exposto, traçados em linhas gerais os grandes marcos do pensamento de David Hume, a saber: a distinção entre ideias e impressões; o princípio da livre associação de ideias na imaginação; a função da memória na ligação entre ideias; a negação da ideia de substância e dos conceitos universais; a origem das relações de causa e efeito; o papel desempenhado pela crença no processo de conhecimento e a crença na existência independente dos corpos, passemos agora a analisar de modo mais detido aquilo que é o escopo do presente capítulo: o tema da identidade pessoal.

\subsection{A identidade pessoal}

Estabelecidas as linhas fundamentais do pensamento de Hume no Tratado da Natureza Humana, cabe-nos agora apresentar sua crítica à noção de identidade pessoal, decorrência lógica da negação que fizera sobre a existência das substâncias. O tema é tratado no Livro I, parte 4, Seção 6, escrito em 1739, e depois retomado no Apêndice feito logo em seguida (1740), no qual o filósofo escocês corrige algumas posições adotadas anteriormente.

Hume começa por dizer que, para alguns filósofos, a identidade pessoal é tão evidente que chegaria a ser indemonstrável (2009, p. 283). Todavia, ele se propõe não somente a negar a evidência dessa identidade, como também a negar sua realidade.

Para negar a identidade pessoal, Hume afirma que não temos a ideia permanente de um “eu”, pois esta não derivaria de nenhuma impressão, vez que as impressões são sempre variáveis e inconstantes: 
... não possuímos nenhuma ideia de eu da maneira aqui descrita. Pois de que impressão poderia ser derivada essa ideia?... Toda ideia real deve ser sempre originada de uma impressão. Mas o eu ou pessoa não é uma impressão, e sim aquilo a que nossas diversas impressões e ideias supostamente se referem. Se alguma impressão dá origem à ideia de eu, essa impressão tem de continuar invariavelmente a mesma, ao longo de todo o curso de nossas vidas - pois é dessa maneira que o eu supostamente existe. Mas não há qualquer impressão constante e invariável... Consequentemente, não existe tal ideia. (HUME, 2009, p. 284).

Além disso, as impressões particulares podem ser pensadas separada e distintamente da ideia de um sujeito pensante, isto é, as ideias e impressões por si mesmas não supõem a noção de um "eu". Acresça-se a isso o fato de que, em seu caso particular, Hume afirma não conseguir pensar no seu "eu" sem se deparar com outra percepção particular:

... elas [nossas percepções particulares] são todas diferentes, distinguíveis e separáveis entre si, podem ser consideradas separadamente, e podem existir separadamente, sem necessitar de algo que sustente sua existência. De que maneira, portanto, pertenceriam ao eu, e como estariam conectadas com ele? De minha parte, quando penetro mais intimamente naquilo que denomino meu eu, sempre deparo com uma ou outra percepção particular, de calor ou frio, luz ou sombra, amor ou ódio, dor ou prazer. Nunca apreendo a mim mesmo, em momento algum, sem uma percepção, e nunca consigo observar nada que não seja uma percepção. (HUME, 2009, p. 283).

Negada a identidade pessoal, Hume estabelece sua célebre comparação da mente com um palco de teatro, onde desfilam sem cessar sucessivas percepções. Os sujeitos pensantes não seriam mais do que feixes de diferentes percepções num perpétuo fluxo:

... arrisco-me a afirmar que os demais homens não são senão um feixe ou uma coleção de diferentes percepções, que se sucedem umas às outras com uma rapidez inconcebível, e estão em perpétuo fluxo e movimento. Nossos olhos não podem girar em suas órbitas sem fazer variar nossas percepções. Nosso pensamento é ainda mais variável que nossa visão; e todos os outros sentidos e faculdades contribuem para essa variação. Não há um só poder na alma que se mantenha inalteravelmente o mesmo, talvez sequer por um instante. A mente é uma espécie de teatro, onde diversas percepções fazem sucessivamente sua aparição; passam, repassam, esvaemse, e se misturam em uma infinita variedade de posições e situações. Nela não existe, propriamente falando, nem simplicidade em um momento, nem identidade ao longo de momentos diferentes, embora possamos ter uma propensão natural a imaginar essa simplicidade e identidade. Mas a comparação com o teatro não nos deve enganar. A mente é constituída unicamente pelas percepções sucessivas; e não temos a menor noção do lugar em que essas cenas são representadas ou do material de que esse lugar é composto. (HUME, 2009, p. 285).

Ora, não havendo em nossa mente mais do que um fluxo contínuo de distintas percepções, Hume questiona donde provém nossa tendência a atribuir unidade aos objetos e a nós mesmos como sujeitos pensantes. Para responder a esse questionamento, começa por 
tentar demonstrar que a unidade que atribuímos aos objetos é uma ficção produzida pela associação de ideias na imaginação, originada pela tendência dessa faculdade a supor identidade onde há diversidade de objetos relacionados entre si (2009, p. 288). Dessa forma, segundo Hume, chegaríamos, através da imaginação, a criar ficções, tais como a noção de substância ou alma, para poder afirmar a unidade de objetos distintos e relacionados entre si. Todavia, mesmo assim, não conseguiríamos nos convencer totalmente da identidade das coisas, por não encontrarmos nada que seja invariável a ponto de justificar essa noção de identidade:

\begin{abstract}
Mas, embora essas ideias de identidade e de uma sucessão de objetos relacionados sejam em si mesmas totalmente distintas, e até contrárias, é certo que, em nosso modo comum de pensar, geralmente as confundimos. A ação da imaginação pela qual consideramos o objeto ininterrupto e invariável e a ação pela qual refletimos sobre a sucessão de objetos relacionados são sentidas de maneira quase igual [...]. A relação facilita a transição da mente de um objeto ao outro, e torna essa passagem tão suave como se contemplássemos um único objeto contínuo. Tal semelhança é a causa de nossa confusão e erro, fazendo-nos trocar a noção de objetos relacionados pela de identidade [...] Nossa propensão para esse erro é tão forte, em virtude da semelhança já mencionada, que o cometemos antes de nos darmos conta disso. E, mesmo que nos corrijamos incessantemente pela reflexão, retornando assim ao modo mais exato de pensar, não conseguimos sustentar nossa filosofia por muito tempo, nem libertar a imaginação dessa inclinação [...] Para justificar perante nós mesmos tal absurdo, frequentemente imaginamos algum princípio novo e ininteligível que conecte os objetos, impedindo sua descontinuidade ou variação. É assim que criamos a ficção da existência contínua das percepções de nossos sentidos, com o propósito de eliminar a descontinuidade; e chegamos à noção de uma alma, um eu e uma substância, para encobrir a variação. (HUME, 2009, p. 286-287).
\end{abstract}

Visando corroborar seu pensamento, Hume passa a apresentar exemplos de atribuições de identidade a objetos materialmente distintos. O primeiro exemplo apresentado é o de uma massa de matéria, à qual é somada ou retirada determinada quantidade insignificante (2009, p. 288). Ora, a partir dessa mudança, haveria uma perda da identidade. Todavia, um observador não hesitaria em afirmar que se trata do mesmo objeto.

Em continuidade ao exemplo acima mencionado, Hume afirma que não é o acréscimo ou perda de uma quantidade insignificante em si que gera a ilusão da manutenção da identidade, mas sim a proporção desse acréscimo ou perda em relação ao todo. Para ilustrar essa ideia, apresenta um exemplo hipotético: acrescentar uma montanha ao planeta Terra. Isso não geraria a perda da identidade do objeto planeta Terra, ainda que o acréscimo de uma montanha em si pudesse gerar a perda de identidade de determinada paisagem.

De acordo com Hume, essa atribuição de identidade a objetos distintos por meio da imaginação se dá principalmente nos casos em que as alterações dos objetos ocorrem de 
maneira gradual, de modo imperceptível a nossa mente, que tende a projetar naturalmente nas observações posteriores de um objeto aquelas percepções feitas anteriormente. Isso explicaria porque durante o processo de gradual alteração de um objeto tendemos a atribuir uma identidade ao mesmo, mesmo percebendo que, ao final do processo, estamos diante de um objeto nitidamente distinto em relação ao que observáramos anteriormente. É o exemplo de vegetais e animais que sofrem uma total transformação ao longo dos anos e, ainda sim, continuamos atribuindo a eles uma identidade, apesar das nítidas alterações na forma, tamanho e substância (HUME, 2009, p. 290). Isso demonstraria, de determinado modo, que é a imaginação quem produz esse artifício da identidade (HUME, 2009, p. 289).

Outro artifício da imaginação seria atribuir uma finalidade comum que unifique todas as partes de um objeto. Dessa forma, ainda que todas as partes se alterem, continuamos a atribuir uma identidade ao objeto, em razão da manutenção de sua finalidade. Poderíamos mencionar como exemplo a hipótese de um navio que sofresse sucessivos reparos e troca de material, permanecendo, contudo, o mesmo navio (HUME, 2009, p. 289).

A preservação da noção de identidade exige, segundo Hume, que a alteração no objeto não seja abrupta nem repentina para o observador. Com efeito, não é a mudança em si que nos leva a negar a identidade de um objeto, mas a mudança que não é esperada, onde não há uma expectativa de uma repentina mudança. Por exemplo, um rio muda o tempo todo, mas tendemos a estabelecer sua identidade, tendo em vista que a mudança num rio é algo que lhe é essencial e, portanto, esperado (HUME, 2009, p. 291).

O mesmo raciocínio que aplicara para negar a identidade dos objetos, Hume passa a utilizar na negação da identidade da mente e do sujeito pessoal. Argumenta ser evidente que cada percepção da mente é distinta e separável das demais. A questão seria saber se podemos dizer se o vínculo que une as diferentes percepções é real ou aparente, fruto da associação de ideias na imaginação. Hume aponta para a segunda opção e destaca que o mesmo mecanismo imaginativo responsável pela falsa sensação de identidade dos objetos é replicado para o caso da falsa percepção da identidade pessoal (2009, p. 292).

A noção de identidade pessoal seria, para Hume, uma projeção que vincula diferentes percepções, produzida a partir das relações de semelhança e de causalidade, as quais permitem um progresso suave e ininterrupto do pensamento ao longo de uma cadeia de ideias.

Segundo Hume, esse progresso do pensamento é possível graças à memória, na medida em que, conforme já mencionamos no início deste capítulo, ela reproduz, de maneira 
vivaz, impressões e ideias passadas, possibilitando o conhecimento da continuidade e da extensão da sucessão de percepções. E, assim como a memória é a responsável pela suposição da identidade entre diferentes objetos, ao permitir que as sucessivas percepções sejam condicionadas pelas percepções anteriores (criando a falsa impressão de que são idênticas), o mesmo raciocínio se aplicaria à ilusão da identidade pessoal, ou seja, seria a memória a responsável pela identidade da mente (HUME, 2009, p. 293).

Rechaçando a noção de identidade pessoal, Hume prefere conceber a mente como um "sistema de diferentes percepções ou diferentes existências, encadeadas pela relação de causa e efeito, e que produzem, destroem, influenciam e modificam-se umas às outras." (HUME, 2009, p. 293). Para ilustrar melhor essa concepção, Hume recorre à comparação da mente humana com uma república na qual, com o passar do tempo, mudam-se os cidadãos (uns morrem outros nascem), muda-se o governo e mudam-se as leis. Todavia, a república permanece. Do mesmo modo, a mente de uma pessoa, por "mais mudanças que sofra, suas diversas partes estão sempre conectadas pela relação de causalidade.” (HUME, 2009, p. 294).

Essa conexão entre as relações de causa e efeito, possibilitadas pela memória, seria o que denominamos, em última instância, o nosso eu:

Como apenas a memória nos faz conhecer a continuidade e a extensão dessa sucessão de percepções, devemos considerá-la, sobretudo por essa razão, como a fonte da identidade pessoal. Se não tivéssemos memória, jamais teríamos nenhuma noção de causalidade e tampouco, por conseguinte, da cadeia de causas e efeitos que constituem nosso eu ou pessoa. (HUME, 2009, p. 294).

Hume esclarece também que a memória não seria a responsável direta e exclusiva pela produção da identidade pessoal. Seu papel seria antes revelar as relações de causa e efeito das nossas percepções. Dessa forma, a cadeia de causalidade que constitui o nosso eu pode ser extendida para além do que abarca diretamente nossa memória e, portanto, o fato de não nos lembrarmos de determinado fato passado não implica na negação do mesmo (HUME, 2009, p. 294).

Por fim, Hume (2009, p. 294-295) conclui afirmando, de maneira cética, não ser possível apresentar um critério para detectar o momento em que surge ou desaparece a identidade pessoal. As controvérsias nessa matéria seriam mais de conteúdo gramatical do que filosófico. 


\title{
1.3 A posição de Hume no Apêndice
}

Num Apêndice escrito pouco depois da publicação do Tratado da Natureza Humana, Hume (2009, p. 672-673) volta a tratar do tema da identidade pessoal, resumindo de maneira clara todos os argumentos que negam as ideias de substância e de um "eu" pensante apresentados anteriormente.

Ainda no Apêndice, após sintetizar seu ponto de vista, Hume apresenta-se claramente insatisfeito com a sua posição anteriormente manifestada no tocante ao tema da identidade pessoal:

\begin{abstract}
Até aqui, meu argumento parece ter uma evidência suficiente. Mas, tendo assim desfeito o laço que prendia todas as nossas percepções particulares, quando passo a explicar o princípio de conexão que as liga, e que nos faz atribuir a elas uma real simplicidade e identidade, percebo que minha explicação é muito deficiente, e só a aparente evidência dos raciocínios anteriores pode ter-me levado a aceitá-la. [...] A presente filosofia, portanto, tem até aqui um aspecto promissor. Mas todas as minhas esperanças se devanecem quando passo a explicar os princípios que unem nossas percepções sucessivas em nosso pensamento ou consciência. Não consigo descobrir nenhuma teoria que me satisfaça quanto a esse ponto. (HUME, 2009, p. 673-674, grifo nosso).
\end{abstract}

Hume concluirá afirmando que não consegue superar uma incoerência entre a defesa simultânea de dois princípios dos quais está firmemente convencido e dos quais não consegue abrir mão: "que todas as nossas percepções distintas são existências distintas; e que a mente nunca percebe nenhuma conexão real entre existências distintas." (Hume, 2009, p. 674). Ressalte-se que, tais princípios não são, em si mesmos, contraditórios, conforme observações de alguns comentadores de Hume que traremos mais adiante no próximo subcapítulo. Portanto, não resta muito evidente entender as razões pelas quais Hume apresentou-se tão descontente com sua posição a respeito da identidade pessoal.

Não achando uma saída em seu pensamento para essa suposta aporia, Hume (2009, p. 674) conclui suas reflexões a respeito do tema apelando para o "privilégio do cético", ao admitir que a dificuldade acima apresentada ultrapassa o seu entendimento, embora não tenha a pretensão de afirmar que a questão seja em si mesma insuperável. 


\subsection{As críticas de alguns comentadores de Hume}

É interessante trazer à tona a posição de alguns dos comentadores e críticos de Hume, que buscaram compreender a razão do seu descontentamento manifestado no Apêndice, tão contrastante com o otimismo orgulhoso com que o filósofo escocês aborda o tema da identidade pessoal ao longo do Tratado.

Os quatro primeiros comentadores, Don Garrett, Copleston, Geoffrey Scarre e Kemp Smith procuram esclarecer as causas do descontentamento de Hume a partir do seu próprio sistema filosófico, ou seja, apresentam críticas mais internas. Os outros três, María Elósegui, Steffan Cuypers e Olavo de Carvalho, apontam para uma crítica mais externa e abrangente, apontando deficiências não somente no tema da identidade pessoal, como também em alguns dos principais pressupostos filosóficos do empirismo de Hume.

Don Garrett chama atenção para o fato de que as duas assertivas apresentadas no Apêndice do Tratado não são inconsistentes entre si, sendo antes inconsistentes com outras crenças de Hume, das quais ele não demonstra a consistência, provindo daí seu descontentamento.

Garrett (1981) enumera seis assertivas provindas do sistema filosófico de Hume (sendo as duas primeiras aquelas explicitadas por Hume no Apêndice), as quais, em seu conjunto, seriam inconsistentes entre si:

Assertiva A: Todas as nossas percepções distintas são existências distintas.

Assertiva B: A mente nunca percebe nenhuma conexão real entre existências distintas.

Assertiva C: A propriedade de qualquer percepção é determinada por suas relações causais e por suas relações de semelhança ou então pela observação de sua conexão real com um sujeito substancial distinto.

Assertiva D: Os papéis causais desempenhados por objetos qualitativamente idênticos (existências distintas) somente podem se diferenciar em virtude de diferenças espaciais ou temporais, a menos que a mente perceba uma real conexão (uma necessária conexão causal) entre ao menos um deles e algum outro objeto distinto.

Assertiva E: Diversas espécies de percepções são não localizáveis.

Assertiva F: É possível que duas percepções qualitativamente idênticas, inclusive aquelas não localizáveis, possam ocorrer em diferentes mentes ao mesmo tempo. 
As duas primeiras assertivas encontram-se no Apêndice, conforme mencionamos. A assertiva $C$ expressa a concepção humiana segundo a qual cada percepção exige um ato de perceber através do qual é inserida numa mente de um sujeito ou entrelaçada junto a outras percepções por meio de relações mentais de semelhança ou causalidade. A assertiva D está ancorada na peculiar definição de causa dada por Hume, que supõe uma relação de anterioridade temporal e contiguidade espacial. Dessa forma, sendo duas percepções qualitativamente idênticas, devem se diferenciar a partir de elementos espaço-temporais, sendo essa uma posição daqueles que, como Hume, entendem não haver na natureza nenhuma conexão real necessária. A assertiva E encontra-se no livro I, parte 4, seção 5 do Tratado, onde Hume trata do tema da imaterialidade da alma. Como exemplo dessa espécie de percepções não localizáveis, Hume (2009, p. 268) menciona os aromas, os sons e as paixões e sentimentos. Por fim, a assertiva F, embora não apareça explicitamente no Tratado, seria facilmente assumida por Hume, segundo opinião de Garrett, tendo em vista que se trata de uma crença do senso comum da qual não se poderia abrir mão, sob pena de se ter de aceitar uma espécie de conexão necessária na natureza, que consistiria na negação de todas as percepções do mesmo tipo daquela cuja existência já se admitiu.

Uma vez reconhecidas as assertivas acima como proposições adotadas por Hume, Garrett demonstrará a inconsistência do conjunto a partir da aceitação da assertiva $F$, que contém a hipótese de duas percepções numericamente distintas, qualitativamente idênticas e espaço-temporalmente simultâneas: como seriam diferenciadas, se não há diferenças em suas relações de semelhança e causalidade, a não ser que aceitemos a possibilidade de tais percepções provirem de sujeitos distintos? Em outras palavras, caso admitíssemos duas percepções não localizáveis que fossem qualitativamente idênticas e numericamente distintas: $\mathrm{P}^{1}$ e $\mathrm{P}^{2}$ (que poderiam representar, por exemplo, o aroma de uma mesma flor ou o som da buzina de um determinado automóvel), como diferenciar $\mathrm{P}^{1}$ de $\mathrm{P}^{2}$, levando em conta que essas percepções se dão simultaneamente, senão admitindo que $\mathrm{P}^{1}$ é uma percepção do sujeito $\mathrm{S}^{1} \mathrm{e}$ $\mathrm{P}^{2}$ é uma percepção do sujeito $\mathrm{S}^{2}$ ?

Uma possível saída para esse dilema seria negar a possibilidade de existirem duas percepções numericamente distintas, qualitativamente idênticas e espaçotemporalmente simultâneas, ou seja, reduzí-las a uma percepção apenas. Todavia, Garrett nos alertará para o fato de que a negação da possibilidade de se conceberem percepções idênticas pensadas por mentes potencialmente distintas seria introduzir um elemento de necessidade na natureza, o que é terminantemente negado desde o começo por Hume, na medida em que o filósofo 
escocês afirma ser a noção de necessidade uma ideia da mente derivada das impressões de contiguidade espacial e sucessão temporal, assim como ocorre com a ideia de causa, conforme a seguinte passagem:

\begin{abstract}
A ideia de necessidade surge de alguma impressão. Nenhuma impressão transmitida por nossos sentidos é capaz de gerar tal ideia. Ela deve, portanto, ser derivada de alguma impressão interna, ou seja, de uma impressão de reflexão. A única impressão interna com alguma relação com aquilo de que estamos tratando é a propensão, produzida pelo costume, a passar de um objeto à ideia daquele que o acompanha usualmente. Essa é, portanto, a essência da necessidade. Em suma, a necessidade é algo que existe na mente, e não nos objetos. E jamais poderemos formar a menor ideia dela se a considerarmos uma qualidade dos corpos (HUME, 2009. p. 199).
\end{abstract}

Dessa forma, Garrett (1981, p. 358) concluirá que a insatisfação acerca do tema da identidade pessoal manifestada por Hume no Apêndice do seu Tratado provém da constatação do fato de que sua concepção sobre a causalidade e a identidade pessoal acaba por negar a possibilidade da existência de mentes distintas com percepções semelhantes e simultâneas, o que seria incompatível com sua visão da natureza, na qual está abolida a necessidade, tendo em vista que, negar a possibilidade de mentes distintas seria estabelecer uma necessidade na natureza. Ora, Hume em seu empirismo, não está disposto a aceitar qualquer tipo de conexão necessária na natureza e, justamente por isso, não poderia afirmar que percepções não localizáveis, idênticas e simultâneas necessariamente derivam de um único feixe de percepções - a mente.

Copleston (1993, p. 287) chama atenção para o fato de Hume destacar o papel capital desempenhado pela memória no processo de conhecimento sem, todavia, especificar suas funções, do que é constituída, ou mesmo se resulta numa faculdade permanente, o que seria contraditório com a afirmação de que a identidade pessoal é uma ficção. Além disso, Copleston questiona como pode a mente ser reduzida a um somatório de percepções distintas entre si, e ao mesmo tempo mantê-las reunidas, constituindo uma espécie de feixe? Seria nossa mente também uma percepção? E como poderia essa percepção conhecer as outras percepções? A falta de uma resposta satisfatória a esses pontos deixa em evidência importantes lacunas no pensamento de Hume e pode ter originado parte do seu descontentamento.

Outro comentador de Hume, Geoffrey Scarre (1983), opina que, embora Hume tenha entendido haver inconsistências na sua explicação do "eu", todavia não soube articular 
de maneira clara essas inconsistências, gerando assim uma infinidade de interpretações acerca das razões que o levaram ao descontentamento expresso no Apêndice.

Juntamente com outros comentadores, Scarre (1983, p. 218) observa que as duas assertivas apresentadas no Apêndice ("Todas as nossas percepções distintas são existências distintas"; e "A mente nunca percebe nenhuma conexão real entre existências distintas") não são inconsistentes entre si, mas sim com a explicação dada acerca da origem da ideia de identidade pessoal.

Scarre chama atenção para o fato de que, no Apêndice, Hume dedica três parágrafos para mostrar que os objetos que distinguimos através de nossas diferentes percepções são tomados por nós como existências distintas e separadas. A insistência nesse ponto constituiria uma pista para entendermos os motivos que levaram Hume a confessar "que minha explicação é muito deficiente, e só a aparente evidência dos raciocínios anteriores pode ter-me levado a aceitá-la." (HUME, 2009, p. 673-674). O descontentamento de Hume proviria, segundo Scarre (1983, p. 129), do contraste entre o modo como concebemos os objetos de nossa percepção, por um lado, e o modo como concebemos os sujeitos perceptores, por outro. Com efeito, a dicotomia fica evidente quando comparamos as perspectivas objetiva e subjetiva: na perspectiva objetiva, se considerarmos dois objetos distintos - esta cadeira e aquela mesa - teremos duas percepções distintas. Já na perspectiva subjetiva "esta cadeira e aquela mesa" constituem um único conjunto ("feixe") de percepções.

Segundo o mesmo autor, não há propriamente uma contradição lógica em envolver a pluralidade de impressões geradas pela pluralidade de objetos numa sequência unificada por relações de semelhança e causalidade (contiguidade espacial e sucessão temporal). Todavia, sabemos que, para expurgar qualquer forma de concepção de um elemento metafísico (sujeito) no qual inerissem diferentes percepções, Hume reduziu o que chamamos de "eu" a um feixe ordenado de percepções distintas unificadas por relações de semelhança e causalidade, entendendo essas relações como a fonte geradora da fictícia ideia de um sujeito permanente.

Ocorre que, conforme observado por Scarre (1983, p. 220), também em termos objetivos podemos distinguir diferentes percepções decorrentes da variedade de objetos, objetos estes relacionados por semelhanças e conjunções constantes, sem, contudo, reduzir essa pluralidade de percepções a um feixe sequencial único. Ora, por que então essas relações de semelhança e causalidade, quando analisadas numa perspectiva subjetiva, seriam capazes 
de unificar diferentes percepções reduzindo-as a uma unidade, se numa perspectiva objetiva não são capazes de reduzir a pluralidade de objetos a um objeto único?

A ausência de resposta a essa questão, longe de provar ser insolúvel o problema da identidade pessoal, torna, contudo, limitada a tentativa de solução através do recurso a relações de semelhança e causalidade (sendo estas últimas sequer uma propriedade real decorrente dos objetos). Seria, portanto, a falta de um elemento unificador análogo no campo da objetividade o que constituiria, segundo opinião de Scarre (1983, p. 220), a razão última do descontentamento de Hume manifestado no Apêndice a respeito de suas próprias explicações dadas no Livro 1, parte, 4, seção 6 do Tratado.

Outra explicação para a origem do descontentamento de Hume apresentado no Apêndice provém de Kemp Smith e consiste na constatação de uma patente contradição, por parte do próprio Hume, no que se refere ao tema da identidade pessoal. Essa contradição decorre do fato de Hume admitir claramente no Livro 2 do Tratado a existência da impressão de um "eu", a qual fora negada expressamente no Livro 1, conforme já tivemos a oportunidade de apresentar neste trabalho. A passagem em que Hume admite de maneira mais explícita a existência da impressão do "eu" encontra-se no Livro 2, parte 1, Seção 11, no 4: "É evidente que a ideia, ou, antes, a impressão de nós mesmos, está sempre presente em nosso íntimo, e que nossa consciência nos proporciona uma concepção tão viva de nossa própria pessoa que é impossível imaginar algo que a supere quanto a esse aspecto" (HUME, 2009, p. $352)$.

De acordo com Kemp Smith (1941, p. 73-76, 169-175, 555-559 apud REIS, 2010, p. 39), essa contradição em Hume se daria em razão de diferentes influências em seu pensamento. Por um lado, Hume assume uma ideia permanente e biológica do $e u$, utilizada para fundamentar e explicar o comportamento humano sob o ponto de vista da filosofia moral (Livro 2), e, por outro, dissolve a unidade e a permanência do eu quando trata especificamente da questão da identidade pessoal (Livro 1). Por constatar essa contradição no interior do seu sistema filosófico, Hume teria manifestado seu profundo descontentamento com as explicações dadas sobre o problema da identidade pessoal no Livro 1.

Contrastante com a crítica de Kemp Smith é a visão de María Elósegui (1993), que busca dar uma explicação para a aparente contradição acima mencionada. Segundo essa comentadora, Hume teria adotado uma abordagem psicológica do "eu" - inovadora para o seu tempo - ao tratar da filosofia moral e política nos Livros 2 e 3, enquanto teria criticado a abordagem ontológica no Livro 1. 
Tal perspectiva psicológica diferencia-se da ontológica, pois focaliza no ato de autorreflexão que gera o reconhecimento de si, na própria condição de sujeito. Como cada ato desse juízo introspectivo é diferente de outro, assim como cada percepção é distinta de outra, então Hume concluirá pela negação da identidade do eu. Ao abordar na mesma obra as diferentes perspectivas, Hume teria suspeitado da contradição posteriormente apontada por Kemp Smith, suspeita que o levaria à insatisfação manifestada no Apêndice a respeito de suas próprias explicações dadas ao longo do Tratado. É o que sintetiza Elósegui:

... uma coisa é que o eu seja o que sou (plano ontológico) e outra que eu me
reconheça como tal, no momento em que apareço ante mim mesmo no plano
epistemológico. Enquanto que o eu transcendental é refratário a toda a reflexão ao
ser completamente não objetivável, o eu empírico é o comparecimento do sujeito na
consciência vital (ELÓSEGUI, 1993, p. 305, tradução nossa).

Segundo Elósegui, Hume utiliza e supõe a existência de um "eu” ao explicar o mecanismo da paixão do orgulho ${ }^{2}$ e ao tratar da simpatia como fundamento das relações sociais. Todavia, na análise feita no Livro 1 sobre a consistência desse "eu”, acabou por negálo.

Nesse sentido, é interessante o paradoxo apontado por Elósegui: se por um lado, Hume negou um "eu" teórico e abstrato, por outro afirmou (HUME, 2009, p. 351) sua existência no campo prático, caracterizando-o pela abertura aos outros, através da simpatia, considerada a qualidade mais notável para receber ou comunicar inclinações e sentimentos. Ora, para simpatizar com os outros, se requer a produção da ideia ou impressão de si mesmo neles, como fonte de vivacidade, além de se supor que haja outros "eus", nos quais reverbera essa mesma ideia ou impressão. Dessa forma, resta mais uma vez evidente que o "eu” negado por Hume no Livro 1, aparece como elemento fundamental para sua filosofia moral e política nos Livros 2 e 3.

Tal negação, segundo a referida autora, proviria do fato de que Hume tinha em mente, no Livro 1, a noção cartesiana da substância pensante, de cunho racionalista, totalmente avessa ao seu empirismo. Com efeito, o cartesianismo, ao rejeitar a ligação entre conhecimento sensível e conhecimento racional (ELÓSEGUI, 1993, p. 304), reconhecendo como conhecimento verdadeiro apenas aquilo que se refere às ideias universais, isto é, o conhecimento racional, acabou por tornar inexplicável o objeto do ato da reflexão subjetiva, 
na medida em que o sujeito, em sua condição de sujeito, jamais pode ser conhecido universalmente, dada sua singularidade essencial.

Uma solução que sanaria a insatisfação do filósofo escocês seria, na opinião de Elósegui, romper com a visão dualista subjacente ao próprio Hume, transportando o eu do incomunicável mundo da substância pensante para a realidade concreta do indivíduo de carne e osso, isto é, reconhecer que o "eu" possui como referente o indivíduo em sua dimensão corporal, não se referindo apenas a sua mente ou a sua alma (1993, p. 306-309).

Essa solução somente seria possível se Hume abrisse mão do seu ceticismo radical que o leva a negar validade e certeza ao conhecimento empírico (ELÓSEGUI, 1993, p. 305306). Uma vez restaurada a união entre a experiência sensível e o conhecimento racional, rompida pelo dualismo cartesiano, a realidade do "eu" poderia ser apreendida pelas diversas formas de experiência albergadas pela perspectiva psicológica - conhecimento do "eu" através do seu agir: autorreflexão; paixões morais e relações sociais - e conhecida racionalmente numa perspectiva ontológica. Restaurada a união entre os sentidos e o pensamento, o problema do "eu" não ficaria reduzido ao campo da crença, conforme fez Hume, e poderia, portanto, ser objeto de análise empírica e racional.

Embora não trate exclusivamente do tema da identidade pessoal em David Hume, é interessante trazer à tona a opinião de Stefaan Cuypers, que em muitos pontos é convergente com as considerações de Elósegui, especialmente ao tratar do eu como sujeito corporal e não mera substância pensante. Na visão de Cuypers (1993), tanto o empirismo com sua redução do sujeito a um feixe de impressões, representado especialmente por Hume, quanto as diversas formas de dualismo, que reduzem o sujeito a uma substância pensante, falham ao assumir um pressuposto comum: a visão atomista da pessoa, considerada um objeto particular de conhecimento introspectivo.

Cuypers considera como traço essencial do atomismo - seja na forma do atomismo lógico, representado pelos empiristas que explicam a identidade pessoal como uma construção lógica da auto-identidade empírica, seja na forma do atomismo metafísico, representado pelo cartesianismo, que considera como causa da identidade pessoal a permanência de uma substância espiritual idêntica a si mesma ao longo do tempo - o fundacionalismo epistemológico, que considera o espaço interior do "eu" como um objeto de

\footnotetext{
2. A autora traz uma série de passagens (HUME, 2009, p. 311-312; 314; 323) em que o filósofo escocês explicitamente admite a existência do eu como referencial da paixão do orgulho.
} 
conhecimento certo e imediato, em contraposição ao conhecimento dos objetos exteriores inclusive o próprio corpo - que seria indireto e falível. Essa dicotomia epistêmica revelaria o dualismo latente em tal perspectiva (CUYPERS, 1993. p. 226-227).

$\mathrm{O}$ atomismo na filosofia da mente propõe que o acesso ao espaço interior do "eu" (autoconhecimento e acesso à mente e seus conteúdos) seria explicado a partir da analogia com um modelo perceptual aplicado aos objetos sensíveis (CUYPERS, 1993, p. 229). Como consequência desse modelo, o "eu" seria encarado sempre como um objeto privado, havendo uma assimetria entre o conhecimento da própria mente (introspecção) e o acesso a outras mentes (percepção). Além de privado, o eu pessoal seria uma substancia psicológica (seja na forma de um "átomo espiritual" do modelo cartesiano, seja na forma de um "feixe de átomos de experiência" do modelo empirista), estática e não corporal (CUYPERS, 1993, p. 232).

A fraqueza dessa visão atomística reside, segundo opina Cuypers, numa falsa analogia entre a introspecção do eu pessoal e a percepção dos objetos, vez que a introspecção não pode ser enquadrada nos moldes da percepção, por três razões. Primeiro, porque o "eu" não é identificável por nenhuma propriedade, nem tem necessidade de sê-lo; diferentemente dos objetos, identificados a partir da percepção das propriedades a eles atribuídas (CUYPERS, 1993, p. 233 e 234). Segundo, porque na introspecção não há possibilidade de erro de identificação - é impossível confundir o meu "eu” com o "eu” do outro, enquanto na percepção há essa possibilidade, pois posso confundir ao olhar pela janela duas árvores de espécies distintas. Terceiro, porque a percepção apresenta sempre dois elementos: o fenomênico e a relação de causa e efeito entre a percepção e o objeto; enquanto a introspecção não apresenta esses dois elementos. Com efeito, numa percepção sensorial é fundamental o aspecto fenomênico, isto é, o como se apresenta aquela perceção ao sujeito. Isso é o que permite diferenciar uma dor de um prazer. Ora, quando se trata da instrospecção, esse aspecto fenomênico fica de fora. No que se refere à causa e efeito, tratando-se de uma percepção, não restam dúvidas quanto à necessidade de um objeto causador daquele efeito perceptivo. Se retirássemos o objeto, não haveria mais percepção, restando quando muito uma alucinação. Todavia, ao considerarmos a introspecção, o elemento causal torna-se desnecessário (CUYPERS, 1993, p. 236-237).

Após identificar e criticar o atomismo como pressuposto dos debates contemporâneos a respeito da identidade pessoal, Cuypers (1993, p. 239) propõe uma visão alternativa, partindo da metafísica descritiva da pessoa de Peter Strawson. A denominação metafísica descritiva surge para diferenciar tal perspectiva das metafísicas revisionistas e 
validatórias. Essa diferenciação está construída em torno da noção de identidade pessoal. As metafísicas validatórias procuram fundamentar o uso linguístico da identidade pessoal numa entidade substancial metafísica (atomismo cartesiano), enquanto as metafísicas revisionistas buscam um uso meramente convencional (atomismo lógico) da noção de identidade pessoal.

A perspectiva da metafísica descritiva está amparada em três princípios semânticos fundamentais. O primeiro deles é que não é possível identificar estados e processos mentais individuais sem atribuí-los a corpos materiais ou corpos pessoais, ambos considerados identificadores básicos da linguagem (CUYPERS, 1993, p. 240). Tal princípio atinge frontalmente a "teoria do feixe", que nega a atribuição de estados mentais a um sujeito. Ademais, distancia-se também da visão cartesiana, no que se refere à consideração do sujeito em sua corporeidade. Com efeito, a substância pensante imaterial de Descartes não é individualmente identificável como sujeito de experiências.

O segundo princípio (CUYPERS, 1993, p. 242) propõe que a adscrição de uma experiência (ou estado mental) a si mesmo, somente é possível caso haja a possibilidade de se adscrever tal sensação a terceiros, ou seja, é impossível uma autodescrição que não inclua uma possibilidade lógica de heteroadscrição. Tal princípio seria uma decorrência do argumento da linguagem privada de Wittgenstein, segundo o qual uma linguagem coerente necessariamente deve ser pública, estando à disposição de qualquer falante e permanecendo sujeita à correção.

O terceiro princípio estabelece que o conceito de pessoa é logicamente anterior primário - em relação aos conceitos de corpo e mente - secundários - não sendo redutível a nenhum destes dois, ou seja, o conceito de pessoa deve incluir predicados mentais e predicados corporais (CUYPERS, 1993, p. 245). Na raiz dessa primitividade encontra-se o duplo uso do conceito de pessoa como agente e objeto de reações morais. Com efeito, a primitividade do conceito de pessoa se torna manifesta à luz do conceito de ação, o qual abarca numa unidade dois elementos distintos: a intenção e o movimento corporal, sem reduzir-se a nenhum deles, nem sendo mera somatória dos dois:

\footnotetext{
Uma ação - por exemplo, escrever uma carta - implica tanto uma intenção de atuar como um movimento corporal, sem que a ação possa ser reduzida a um destes dois aspectos à somatória dos dois. Quando se adverte que o conceito de ação não é analisável em termos de conceito de pura intenção, nem em termos de conceito de movimento corporal, resta compreensível porque o conceito do centro da ação - a pessoa - deve ser, da mesma forma, não analisável (CUYPERS, 1993, p. 246, tradução nossa).
} 
Quanto às reações morais, também essas revelam a primitividade do conceito de pessoa, visto que reagimos, com atitudes morais ou sentimentos, instintivamente como pessoas, ou seja, na nossa maneira natural de comportar-nos frente aos outros, primariamente nos relacionamos com outras pessoas considerando-as como pessoas, e não como corpos ou mentes (CUYPERS, 1993, p. 246).

Cuypers (1993, p. 247-248) conclui que, dos três princípios acima arrolados, emergem três características que podem compor um conceito de pessoa apropriado ao seu uso na linguagem, entendida como um agente corporal, público e dinâmico. Corporal, porque as propriedades mentais não podem prescindir de uma base material (primeiro princípio); público, pois sua base corporal é identificável e, ademais, por ser capaz de compreender e atribuir experiências a terceiros (segundo princípio); dinâmico, pois atua sobre o mundo e é objeto de ações de outras pessoas (terceiro princípio). Como podemos perceber, tal definição contraria frontalmente a visão atomista da pessoa, considerada entidade imaterial, privada e estática.

Outra crítica que expõe a debilidade de uma série de pontos capitais do pensamento de Hume, especialmente aqueles que servirão de base para a negação da identidade pessoal, é aquela apresentada por Olavo de Carvalho, em três aspectos fundamentais.

No primeiro, Olavo de Carvalho (2007a, p. 32 e 33) chama atenção para o fato de que Hume acaba concebendo cada percepção, impressão ou ideia como uma entidade mental totalmente distinta e separada das demais. Neste sentido, vale a pena recordar o princípio ao qual Hume não quis renunciar e que expressou no Apêndice: "todas as nossas percepções distintas são existências distintas" (HUME, 2009, p. 174). Além de distintas entre si, essas impressões gozariam de independência em relação aos objetos exteriores (assim como conceitos puramente lógicos ou matemáticos), na medida em que o ceticismo de Hume deixa de fundamentar a existência delas numa realidade extramental, conforme ilustra a seguinte passagem:

Quanto às impressões provenientes dos sentidos, sua causa última é, em minha opinião, inteiramente inexplicável pela razão humana, e será sempre impossível decidir com certeza se elas surgem imediatamente do objeto, se são produzidas pelo poder criativo da mente, ou ainda se derivam do autor do nosso ser [...]. Podemos sempre fazer inferências partindo da coerência de nossas percepções, sejam estas verdadeiras ou falsas, representem elas a natureza de maneira correta ou sejam meras ilusões dos sentidos. (HUME, 2009, p. 113, grifos nossos). 
Ora, tal concepção cética parece-nos problemática, visto apontar para uma espécie de caráter inatista das impressões, cujos conteúdos mentais, a nosso ver, deveriam se fundamentar na experiência dos sentidos, tendo em vista que essa fundamentação é muito mais coerente com as características das espécies de impressão estabelecidas pelo próprio Hume: a sensação, a paixão e a emoção $(2009$, p. 25).

Além disso, o próprio conceito de impressão supõe certo grau de consciência, vez que uma impressão que não fosse recebida numa consciência jamais seria uma impressão. Afinal, a própria experiência cotidiana nos revela que a maior ou menor consciência de uma impressão é proporcional à intensidade da mesma. Assim, não se pode separar uma impressão sensível de uma forma ao menos elementar de consciência, que atribua tal impressão a um centro autorrefente.

Com efeito, caso não houvesse um centro de referência que recebesse uma sensação, seria impossível expressá-la verbalmente. Ou seja, ter uma sensação e expressá-la verbalmente exige necessariamente um centro referencial contínuo, sob pena da expressão verbal não ser referida a nada, dado que a expressão verbal de uma sensação supõe a ligação entre um agente - a própria sensação - e um paciente, o sujeito que a recebe. Para ilustrar melhor a necessidade dessa ligação, pode-se imaginar o exemplo de um homem sob efeito de hipnose e que não refere a si as percepções de dor às quais é submetido. Somente para este tipo de sujeito, não haveria uma diferença entre receber uma martelada no dedo ou não recebê-la, pois em ambas as situações ele é incapaz de referir a si a martelada recebida. $\mathrm{O}$ sujeito ao que Hume nega uma identidade permanente seria, na opinião de Olavo, nada menos do que um sujeito hipnotizado.

O segundo aspecto crítico (DE CARVALHO, 2007a, p. 20-23) decorre do primeiro. Além de não estarem separadas da consciência, podemos dizer também que a separação perfeita entre cada impressão somente pode ocorrer no campo mental, por meio de hipotéticos exercícios intelectuais, e não na estrutura da experiência, a qual é una (num mesmo instante somos submetidos a uma série de impressões simultâneas decorrentes de diversos objetos e captadas ao mesmo tempo pelos nossos diferentes sentidos) e contínua (conforme já veremos no exemplo do choque entre duas bolas de bilhar). Além disso, se todas as nossas sensações fossem separáveis no momento da experiência e agrupadas de acordo com relações de semelhança, como se faria isso sem um sujeito que fizesse tal relação? Poderiam tais relações de semelhança brotar espontaneamente das próprias impressões? 
Ora, Hume parece confundir exercícios mentais com dados da experiência. E espera-se de um empirista que ele não reduza a realidade da experiência a uma projeção de decomposições mentais pré-fabricadas. Com efeito, para utilizar um exemplo do próprio Hume (2009, p. 687-688), na hipótese de uma bola de bilhar em movimento que se choca e transmite o movimento à outra bola de bilhar que estava parada, o que existe na experiência é um movimento contínuo que se transmite de uma bola à outra. A separação em dois movimentos, decorrentes de dois momentos absolutamente distintos, o imediatamente anterior e o imediatamente posterior ao choque, ocorre apenas mentalmente, pois a sensação nesse caso é uma só - sensação de continuidade do movimento transferido de uma bola à outra - e não decomposta em partes distintas e perfeitamente separáveis. A separação somente ocorre mentalmente, num momento posterior à experiência do acontecimento. Em outras palavras, na filosofia de Hume seriam dois movimentos e, portanto, duas sensações atomizadas: o da primeira bola em movimento e o da segunda que se inicia no instante do choque. Essa divisão é mental e a posteriori em relação ao fenômeno observado, assim como a célebre tartaruga do paradoxo de Zenão somente não seria ultrapassada por Aquiles no experimento mental proposto pelo discípulo de Parmênides.

O terceiro aspecto crítico (DE CARVALHO, 2007a, p. 31 e 32) consiste na confusão estabelecida entre os conceitos de identidade, distinção e semelhança. Ora, na linguagem corrente, não há uma distinção muito clara entre esses termos. Todavia, na linguagem filosófica, as diferenças podem ser decisivas na exposição de um pensamento. Aqui entendemos por identidade e semelhança relações derivadas da unidade, sendo que a identidade se refere à unidade na substância ou na essência, enquanto a semelhança se refere à unidade na qualidade acidental. A distinção, por sua vez, é entendida como negação da identidade (ALVIRA; CLAVELL; MELENDO; 1993, p. 169). Isso não quer dizer que exijamos que Hume se atenha às definições dadas acima. Todavia, ainda que o filósofo escocês adotasse outro entendimento acerca do significado dos conceitos de identidade, semelhança e distinção, todavia restou claro que seu uso no Tratado foi no sentido de entender o termo semelhança como um grau menos intenso de igualdade, enquanto identidade seria um grau de completa igualdade. Esse pensamento corresponde também ao uso desses conceitos na linguagem corrente.

Pois bem, Hume nega que uma mesma impressão possa se repetir ao longo do tempo e afirma que as impressões são distintas entre si, embora reunidas a partir de relações de semelhança. Ora, para que duas impressões sejam distintas, é logicamente necessário que 
cada uma delas seja idêntica a si mesma, tendo em vista que o conceito de distinção decorre e exige a negação da identidade. Também se deve ter em conta que duas coisas não podem ser semelhantes se não tiverem algum elemento de unidade entre si, visto o conceito de semelhança também supor o de unidade, constituindo-se numa forma atenuada - em menor grau - desta.

Por fim, gostaríamos de acrescentar uma última crítica de nossa autoria, inspirada a partir das refutações feitas pelo cientista e filósofo contemporâneo Wolfgang Smith ao que ele denominou bifurcacionismo dualista cartesiano, que entendemos estar presente em um dos pressupostos empiristas de Hume. Nas palavras de Smith:

Essa tese depende de uma suposição epistemológica, um postulado idealista, podemos dizer, que afirma que o ato da percepção sensível termina, não em um objeto externo como comumente acreditamos, mas em um tipo de representação subjetiva. De acordo com essa visão, a maçã vermelha que percebemos existe de alguma forma em nossa mente ou consciência; é uma imagem subjetiva, uma fantasia que a humanidade confundiu com um objeto externo por todo esse tempo. (SMITH, 2000, disponível em < http://cientificismo.pen.io/>).

Com efeito, Hume reduziu o conhecimento às sensações subjetivas, ao duvidar da possibilidade de um acesso ao mundo extramental em si mesmo, visto que nossas percepções subjetivas seriam o termo final do processo de conhecimento. Manifestação desse posicionamento é a consideração de que a existência dos corpos é objeto de crença. Seria também objeto de crença a existência da mente perceptora, uma vez que, segundo Hume, nosso único acesso a ela seria através das nossas próprias percepções.

Antes de Hume, Descartes já separara a realidade em res extensa - o objeto em si, e res cogitans - sua representação na mente, subjetivando as qualidades sensíveis da realidade e reduzindo os entes à sua extensão quantitativa, conforme se pode atestar, por exemplo, na seguinte passagem:

... reconheci que não havia nada que pertencesse à natureza ou essência do corpo, mas apenas que o mesmo é uma substância em longitude, largura e profundidade, capaz de muitas figuras e de diversos movimentos, e que suas figuras e movimentos não eram outra coisa do que modos, que não podem jamais ser sem ele; mas que as cores, odores, sabores e outras coisas semelhantes não eram mais do que sentimentos. (Respuesta a las Sextas Objeciones, AT, IX-1, p. 239 apud SANTACRUZ, 1991, p.68, tradução nossa).

Por sua vez, Hume radicalizou ainda mais esse reducionismo ontológico, limitando nosso acesso mental às impressões, que sequer poderiam ser atribuídas a um sujeito 
que não fosse ficcional. Ora, conforme já mencionamos, é contraditório separar uma sensação de um centro autorreferente. Portanto, não faz sentido falar em qualquer forma de sensação que não suponha um sujeito perceptor. Ademais, o próprio pressuposto bifurcacionista cartesiano que subjaz à visão de Hume é extremamente questionável dos pontos de vista filosófico e científico, ainda mais se levarmos em conta a teoria da percepção visual proposta pelo cientista James Gibson, conforme assinala W. Smith (2014, p. 101-133).

Em seus estudos, Gibson conclui que a percepção visual provém diretamente do ambiente em seu contexto, e não através da interposição de uma imagem, seja produzida a partir da retina, seja a partir do córtex cerebral. Nas palavras do cientista:

\begin{abstract}
Não é necessário supor que coisa alguma seja transmitida ao longo do nervo ótico no ato de percepção. Não precisamos acreditar nem que uma imagem invertida e nem um conjunto de imagens são entregues ao cérebro. Podemos pensar a visão como um sistema perceptual, do qual o cérebro é apenas uma parte. Os olhos também são parte desse sistema, uma vez que as informações que chegam à retina levam a ajustes oculares e, com isso, as informações retinianas alteradas, e assim por diante. $\mathrm{O}$ processo é circular, e não uma transmissão unilateral. O sistema olhos-cabeçacérebro-corpo registra as invariantes na estrutura da luz ambiente. $\mathrm{O}$ olho não é uma câmera que forma e envia uma imagem, nem a retina é meramente um teclado que pode ser tocado pelos dedos da luz. (GIBSON, 1986, p. 61 apud SMITH, 2014, p. 112).
\end{abstract}

Ou seja, o ato perceptivo não se reduz ao processamento de estímulos capturados pela retina, mas contém também - e principalmente - um conjunto de informações contextuais capturadas diretamente do ambiente externo. Isso significa que parece ser mais acertado defender um realismo perceptual direto, ou seja, nossa percepção dos objetos externos se dá diretamente e não por meio da interposição de imagens mentais - impressões ou ideias na linguagem de Hume - fabricadas pela imaginação ou pelo processamento de estímulos nervosos, como bem expôs W. Smith:

São descobertas como essa que enfim levaram Gibson a abandonar o postulado de que a percepção visual se baseia em imagens [...] Com o tempo, Gibson concluiu que a percepção se origina de uma estrutura, até então desconhecida, inerente à luz ambiente: e essa é a descoberta que inaugura a chamada abordagem 'ecológica' da percepção visual [...]. A ótica ecológica difere significativamente da ótica física. A diferença advém, em primeiro lugar, do fato de que a ótica ecológica se ocupa da luz 'ambiente', enquanto distinta da luz radiante: 'A luz radiante diverge a partir de uma fonte de energia; a luz ambiente converge para um ponto de observação. [...] Luz radiante é energia; luz ambiente pode ser informação [...]. Essa nova descoberta permite entender melhor o fato da percepção, vez que numa ótica reduzida ao paradigma imagético não se consegue explicar como pontos de sensação cerebral, caracterizados unicamente por brilho e cor, podem ser capazes de reconstruir o ambiente fenomênico. Ademais, a proposta de Gibson permite explicar como se dá a percepção de profundidade que temos: o próprio arranjo ótico especifica as 
superfícies, as texturas e a disposição do ambiente, o que significa que a terceira dimensão, com efeito, não é construída ou, de algum modo, deduzida de uma imagem plana, e sim percebida diretamente: a percepção de profundidade, descobrimos, não é realmente um processo em duas etapas, como a psicologia da imagem visual fora obrigada a supor.

$[\ldots]$

De acordo com a teoria de Gibson, o que percebemos é, na verdade, o ambiente. As teorias baseadas nas sensações, por outro lado, não podem ser objetivas: aquilo que uma sensação especifica, afinal, não é uma realidade externa, mas o estado de um receptor, o que é muito diferente. E, como aponta Gibson, é precisamente porque as sensações não veiculam conhecimento do mundo externo, que as teorias baseadas nas sensações são necessariamente construtivistas. Mas o resultado final do 'processamento', na melhor das hipóteses, pode ser algum tipo de representação. Se o termo da percepção visual de fato é externo, como insiste Gibson, então segue-se disso que as teorias baseadas nas sensações, ipso facto, são falsas: pois, é desnecessário dizer, nenhuma construção ou processamento pode dar lugar a um objeto ou acontecimento pertinente ao ambiente. Descobrimos que, ao rejeitar o velho axioma de que a percepção se baseia nas sensações e substituí-lo por essa noção revolucionária de 'apreensão de informação', Gibson finalmente abre caminho para uma teoria realista da percepção visual. (SMITH, 2014, p. 102, 103, 107, 112, 119).

Enfim, não se pode reduzir o ato da percepção ao limite das sensações subjetivas, muito menos se as considerarmos independentes da realidade extramental, tal como Hume propunha.

Ante todo o exposto neste subcapítulo, pudemos perceber uma série de lacunas e contradições tanto nos pressupostos quanto no desenvolvimento da negação da noção de identidade pessoal na filosofia de David Hume. Don Garrett chamou-nos atenção para a necessidade de se admitirem mentes distintas para sustentar a afirmação de Hume segundo a qual todas as nossas percepções seriam existências distintas, a partir da possibilidade aceita pelo filósofo escocês de haver percepções qualitativamente idênticas e temporalmente simultâneas acerca de objetos não localizáveis. Ora, neste caso, as percepções somente seriam distintas se realizadas por mentes distintas, cuja identidade fora negada por Hume. Copleston sublinhou a ausência de explicação para o funcionamento da memória e para seu caráter de permanência, em evidente contradição com a redução da mente a sucessivos feixes de impressões. Geoffrey Scarre observou que Hume foi incoerente ao atribuir um efeito de unidade às relações de semelhança e causalidade que constituem a mente perceptora, sem atribuir tal efeito à pluralidade de objetos percebidos, os quais também estariam conectados por relações de semelhança e causalidade. Kemp Smith percebeu a contradição entre a aceitação da impressão do "eu" no livro 2, expressamente negada no livro 1. Maria Elósegui chamou atenção para a impossibilidade de se compatibilizarem as perspectivas ontológica 
(livro 1 do Tratado) e psicológica (livro 2 do Tratado), a partir de um pressuposto exclusivamente cartesiano da noção de sujeito. Stefaan Cuypers criticou a visão atomista da pessoa, pressuposta na negação da sua identidade por parte do filósofo escocês. Esse atomismo filosófico levou Hume a considerar o "eu” como uma substância imaterial e estática acessível apenas pela via do conhecimento introspectivo, o que contraria a proposta de Cuypers, que consiste na consideração da pessoa como agente corporal, público e dinâmico, tal como nos revela o uso da linguagem. Complementando as críticas estabelecidas por esses comentadores, também expusemos a crítica feita por Olavo de Carvalho, chamando atenção especialmente para o aspecto contraditório do empirismo de Hume, concebendo as impressões como realidades puramente mentais e não fundamentadas na experiência. Por fim, destacamos a proposta de Wolfgang Smith por um realismo perceptual direto, sustentada pela teoria da percepção visual de James Gibson.

Estabelecidas essas críticas, parece-nos que a dissolução da identidade pessoal operada pela filosofia de Hume aparenta conter algumas contradições e lacunas. A nosso ver, a visão cética e fragmentária do mundo presente na filosofia de Hume não fornece elementos necessários para uma compreensão mais profunda do sujeito humano e do seu agir.

No próximo capítulo, exporemos a Antropologia Filosófica de Henrique Cláudio de Lima Vaz, que apresenta o conceito de pessoa como uma totalidade resultante da articulação de uma série de categorias realizadas em cada indivíduo humano. Entendemos que a proposta do filósofo brasileiro confere sustentação teórica para uma defesa da identidade da pessoa, apresentando-se como uma alternativa filosófica mais promissora do que a fragmentação operada por Hume. 


\section{Capítulo 2: A noção de pessoa na Antropologia Filosófica de Henrique Vaz}

A concepção de pessoa no pensamento de Henrique Vaz surge ao final de sua Antropologia Filosófica, como um corolário unificador de diversas categorias que expressam os distintos aspectos da vida humana. Para obtermos uma correta compreensão da natureza da pessoa humana no pensamento do filósofo brasileiro, acompanhemo-lo em seu itinerário filosófico através de seu próprio dinamismo dialético, começando por entender o seu método.

\subsection{O método dialético de Henrique Vaz}

Henrique Vaz busca fazer uma releitura da metafísica de Tomás de Aquino a partir da dialética, utilizada como método de reflexão. Ele a entende no sentido clássico como um certo "caminhar através do lógos articulando proposições que se implicam uma à outra" (OLIVEIRA, C., 2013, p. 66), ou seja, tal método pressupõe um diálogo com regras próprias implícitas ao próprio movimento do discurso e deságua numa definição consensual, na forma paradigmática dos diálogos socráticos.

O pensamento dialético de Henrique Vaz sofre forte influência de Platão e Hegel, considerados por ele os dois grandes paradigmas desse método (OLIVEIRA, C., 2013, p. 89), influência expressa na tentativa de pensar as categorias (ideias) da sua época na inteligibilidade do movimento histórico.

A partir da influência platônica, Henrique Vaz entende que as categorias são formuladas visando solucionar, numa ideia unificadora, as aporias (contradições) concretas surgidas no tempo em determinada cultura. Com efeito, a partir da análise que faz de alguns diálogos platônicos, Henrique Vaz entende haver neles uma unidade metodológica, na qual são identificadas aporias no pensamento grego da época, expressas sempre em formas duais conflitantes, cuja solução se encontra na aplicação ao caso concreto da ideia contemplada na teoria. Por exemplo, no Fédon, a ideia de vida supera numa unidade final a oposição entre liberdade e destino. Seguindo o mesmo método, no Banquete, a ideia do belo supera a aporia do lógos e do eros. Tais constatações levaram Henrique Vaz a concluir que: 
os diálogos de Platão devem ser lidos [...] segundo a correspondência, definida pela direção e pelos estágios do caminho dialético, entre uma aporia concreta presente na cultura grega da época e a Ideia que brilha ao termo do caminho iluminando-o retrospectivamente e dissipando a aporia que está no seu início. (VAZ, Filosofia e Cultura na tradição do Ocidente. Síntese, n. 63, 1993, p. 533-578 apud OLIVEIRA, C., 2013, p. 69).

Ao conceber as aporias como problemas práticos e históricos e as ideias como soluções reais para esses problemas, ainda que tais ideias sejam de natureza principiológica, a dialética platônica constitui-se, na opinião de Henrique Vaz, como ontologia. Com efeito, a dialética platônica é ontologia na medida em que: “... descobre nas 'aporias' concretas que embaraçam o ateniense do IV século a implicação de um absoluto de inteligibilidade - a Ideia - capaz de dar consistência a uma nova visão do mundo e de dar assim um sentido à vida humana”. (VAZ, Escritos de Filosofia VIII: Platonica. 2011, p. 66 apud OLIVEIRA, C., 2013, p. 71).

Da mesma forma que Platão, segundo opinião de Henrique Vaz, também Hegel encontrou, no seu tempo, uma série de aporias históricas (Estado moderno e direitos individuais; fé e iluminismo; racionalismo e empirismo), nas quais identificou a dilaceração da cultura provocada pela impossibilidade de se conciliar a tradição grega, o cristianismo e a modernidade. E, assim como Platão, Hegel buscou reconduzir o múltiplo à unidade de sentido, com a diferença de que, diferente da imutabilidade da ideia platônica, o filósofo alemão enxergou no termo do movimento histórico a capacidade de unificar as sucessivas contradições presentes nas etapas anteriores: “ [A filosofia] chega sempre muito tarde. Enquanto pensamento do mundo ela aparece somente depois que a realidade cumpriu seu processo de formação..." (HEGEL, Grundlinien der Philosophie des Rechtes, p. 17 apud OLIVEIRA, C., 2013, p. 86). Dessa forma, a dialética apresenta-se como exercício de rememoração do passado a fim de compreender o presente. Tal rememoração torna-se possível ao final dos três momentos da dialética hegeliana: a universalidade do conceito abstrato, seguida e negada pela particularidade dos acontecimentos históricos e, por fim, superada pela elevação da particularidade à inteligibilidade do universal no terceiro momento (singularidade), quando a Razão Absoluta reinstaura a unidade realizada na concretude da história e não mais na universalidade abstrata do conceito (OLIVEIRA, C., 2013, p. 84).

Inspirando-se em Platão e Hegel, Henrique Vaz também busca dar uma resposta positiva às aporias do seu tempo, tentando reconduzir o múltiplo ao uno, a fim de encontrar 
um sentido para a realidade. Todavia, diferencia-se de Platão ao assumir a matriz antropológica moderna, que pensa a subjetividade a partir de sua historicidade, rompendo com o horizonte cosmológico e imutável da antiguidade clássica (OLIVEIRA, C., 2013, p. 93). E diferencia-se de Hegel na concepção acerca da origem do ser, que no filósofo alemão encontra-se maximamente abstrato e desprovido de qualquer determinação e facticidade, num estado de pura logicidade, cuja intrínseca contradição entre ser um puro ser e ser um puro vazio faz brotar dialeticamente a negação e, a partir dela, a determinação do concreto, cujo movimento sucessivo na história preencherá de determinação e finitude o vazio original do Absoluto.

Nesse sentido, Alejandro Llano sintetiza bem esse aspecto da filosofia de Hegel: "Este ser é pura abstração e, por isso, é o absolutamente negativo, que, tomado também imediatamente, é o nada. Assim, neste primeiro estado, pode-se afirmar que o puro ser e o puro nada são o mesmo". (LLANO, 2004, p 127-128).

Ora, não é essa a concepção de ser assumida por Henrique Vaz, que defende a pura positividade do começo, através do Absoluto Subsistente e Criador, por meio do qual o finito é posto na existência e sem o qual não se fundamenta o discurso dialético. Para Henrique Vaz, é a partir da relação com o infinito transcendente que surge o movimento de autodesenvolvimento do finito, sendo o Absoluto a razão última da inteligibilidade do movimento dialético expresso no discurso (OLIVEIRA, C., 2013, p. 91).

No método de Henrique Vaz, o discurso é organizado em três etapas. Na primeira, através do contato empírico com a aporia concreta, é delimitado o objeto de reflexão da realidade. Tal etapa engloba dois planos de compreensão do objeto de reflexão: a précompreensão e a compreensão explicativa. O primeiro plano se caracteriza pelo senso comum, uma experiência natural inserida num contexto simbólico e cultural de determinada época. Cada objeto de reflexão será compreendido de maneira peculiar de acordo com o contexto cultural no qual está inserido o sujeito que o conhece. O segundo plano, isto é, a compreensão explicativa, constitui-se pelo conjunto de informações aglutinadas pelas ciências experimentais, a partir dos cânones metodológicos específicos de cada ciência particular (VAZ, 1998, p. 159).

$\mathrm{Na}$ segunda etapa, é elaborada a construção noética das categorias visando exprimir da melhor forma possível os objetos de reflexão dados empiricamente. Essa elaboração dá-se no plano da compreensão filosófica, que ultrapassa a condição de mera soma dos resultados alcançados pela explicação científica, na medida em que considera o objeto 
enquanto ser, transcendendo os limites metodológicos das ciências experimentais (VAZ, 1998, p. 159). A construção noética das categorias ocorre através da suprassunção da natureza na forma, pela mediação do sujeito, tendo-se, então o esquema $\mathrm{N}-\mathrm{S}-\mathrm{F}$. O sujeito é mediador de três maneiras: empiricamente - como mediador das diversas imagens do objeto de realidade na pré-compreensão -, abstratamente - como sujeito do conhecimento cientificamente metódico sobre o objeto de realidade - e transcendentalmente - como sujeito que institui um logos no qual esse sujeito dá razão do objeto de realidade -, a partir do que é conhecido empírica - plano da pré-compreensão - e abstratamente - plano da compreensão explicativa. (VAZ, 1998, p. 165-166).

$\mathrm{Na}$ terceira etapa, a dialética, dá-se a organização articulada das categorias filosóficas numa unidade sistemática de sentido que supera a aporia que deu origem ao movimento da razão (OLIVEIRA, C., 2013 p. 91-92). Essa organização articulada supõe uma relação de oposição entre as categorias e de suprassunção progressiva destas de modo a constituir a ordem do discurso segundo os princípios da limitação eidética, da ilimitação tética e da totalização. O princípio da limitação eidética faz o conhecimento exprimir o objeto num conceito, que é sempre limitado. Por isso, geralmente são necessárias várias categorias para exprimir um objeto tal como se apresenta na realidade. Por sua vez, o princípio da ilimitação tética introduz a negatividade na limitação eidética, ao fazer referência ao ser da realidade, irredutível a qualquer forma de categorização. Com efeito, o ser está no objeto da realidade e também na categoria que o expressa, mas não se reduz a nenhum deles, dada sua natureza transcendental, que o situa para além de todo gênero. A partir da introdução desse elemento de negatividade, o princípio da ilimitação tética dá origem "à oposição entre as categorias que leva adiante o movimento dialético do discurso" (VAZ, 1998, p. 167). Por fim, o princípio da totalização permite que o discurso não perca nunca a referência à realidade, evitando reduções imanentistas e mantendo "a ilimitação tética apontada para o horizonte último do ser" (VAZ, 1998, p. 167).

De acordo com Henrique Vaz, aplicando tal método ao objeto da antropologia filosófica, teremos o seguinte processo: na primeira etapa dá-se a delimitação do objeto de conhecimento, o homem, e sua problematização (aporia). Essa primeira etapa compreende dois planos: a experiência do senso comum e as observações feitas pelas ciências do homem. Nessa primeira etapa ocorrem duas dificuldades: a multiplicidade de pré-compreensões do homem, de acordo com as diferentes culturas em diferentes épocas, e a especialização das ciências experimentais, cada uma delas ocupando-se de algum aspecto particular da vida 
humana. Na segunda etapa, temos o processo geral de conceituação filosófica do homem, pelo qual se constroem as categorias fundamentais de modo metodicamente ordenado. Uma dificuldade particular da antropologia filosófica é que seu objeto, o homem, é também o sujeito da relação de conhecimento, tornando necessário um desenvolvimento discursivo e conceitual próprio para essa subjetividade, através da qual o homem busca dar razão de si mesmo (VAZ, 1998, p. 164).

Tendo em vista esse objeto e esse itinerário, a antropologia filosófica encara a complexidade do fenômeno humano a partir de algumas linhas fundamentais, construídas em torno dos conceitos de estrutura, relação e unidade. Quanto à estrutura ou os níveis ontológicos do homem, podemos distinguir três dimensões: a somática - categoria do corpo, a psíquica - categoria do psiquismo, e a espiritual. Quanto à relação, podemos distinguir a relação com o mundo - a categoria da objetividade, com o outro - a categoria da intersubjetividade, e com o Absoluto - a categoria da Transcendência. Quanto à unidade, ou seja, do ser humano como pessoa, pode-se falar de unificação - categoria da realização, e de ser-uno - categoria da essência. Assim, no conceito de pessoa, tem-se a palavra final da antropologia filosófica, síntese unificadora das categorias de estrutura e relação (VAZ, 1998, p. 167/168).

Na categoria da pessoa, Henrique Vaz entende encontrar a síntese unificadora que coroa o edifício da antropologia filosófica. Antes de analisarmos essa categoria, façamos uma breve análise das demais categorias que ela unifica, as quais nos servirão para compreender melhor o pensamento do filósofo brasileiro.

\subsection{As categorias de estrutura}

Pode-se conceber a estrutura ontológica do homem a partir de três dimensões fundamentais: a somática, a psíquica e a espiritual. Na dimensão somática, temos como categoria fundamental o corpo próprio, com uma intencionalidade que transcende o corpo físico-biológico. Essa intencionalidade confere ao homem uma presença ativa no mundo, por meio da qual se constitui um espaço-tempo próprio psíquico do sujeito, que se conjuga com o espaço-tempo físico-biológico do mundo (VAZ, 1998, p. 177). A partir da categoria do corpo 
próprio, é possível superar a dicotomia entre a coisificação do corpo, reduzido a um mero objeto a mais do mundo físico, e a redução do homem ao aspecto espiritual (VAZ, 1998, p. 180).

A categoria do corpo próprio, ao incluir a intencionalidade na morfologia do corpo humano, realça a sua função simbólica (VAZ, 1998, p. 175) na medida em que aponta para além dele mesmo, ao ser fonte de expressão do mundo interior próprio de cada ser humano. Esse caráter simbólico não exige necessariamente uma visão dualista, isto é, não exige que concebamos a essência humana como a justaposição de duas substâncias separadas e distintas: a material (corpo) e a espiritual (alma). Com efeito, Henrique Vaz entende que o corpo humano é suprassumido pelo sujeito e não possuído por este como um mero objeto, mas sim integrado pelo próprio sujeito numa unidade que se poderia expressar dialeticamente como identidade na diferença. Em outras palavras, o homem é o seu corpo, mas não se reduz ao seu corpo (VAZ, 1998, p. 182).

Esse caráter simbólico do corpo, apontando para a interioridade humana, é também observado por Ricardo Y. Stork, que vê na morfologia do corpo a interpenetração entre a biologia e as funções intelectuais exclusivas do ser humano. Na opinião desse autor, o corpo humano tem um caráter sistêmico no qual a biologia está a serviço das funções intelectivas, não se podendo compreender isoladamente alguns dos seus elementos constitutivos, tais como o bipedismo, a posição livre das mãos, a postura ereta e vertical da coluna vertebral, a posição frontal dos dois olhos e seu maior e peculiar desenvolvimento cerebral. Como manifestação de que o homem é "corpo inteligente ou inteligência corporizada" (2005, p. 32), Stork observa as peculiaridades biológicas da mão e da voz humana:

\footnotetext{
Por exemplo, as mãos são um instrumento inespecífico, quer dizer, "multiuso", pensado para ser "instrumento de instrumentos" e de linguagens: podem rasgar, agarrar, bater, abrir, apalpar, saudar, mostrar ódio ou respeito ou indiferença, destacar, etc. Servem para tudo porque são livres: não são garras, nem patas, mas uma realidade "aberta". As mãos são expressivas, pois acompanham ao rosto e as palavras. São um instrumento ao serviço do sistema inteiro que é o corpo e o espírito humano.

Pode-se fazer notar que o homem não tem apenas voz, mas palavra, voz articulada, que exige uns órgãos especiais - cordas vocais, língua, modo de respirar - que permitem a modulação dos ruídos para convertê-los em sons articulados, inteligentes, inteligíveis. Se não tivéssemos lábios finos, língua flexível, dentes e molares etc., não poderíamos falar. Também não poderíamos fazê-lo sem cordas vocais. (STORK, 2005, p. 31).
} 
Ao considerar que o corpo próprio aponta para algo que está além dele, Henrique Vaz adentra na segunda dimensão humana, expressa pela categoria do psiquismo. Com efeito, se pelo corpo o homem possui uma presença imediata no aqui e agora do mundo, pelo psiquismo essa presença se dá mediatizada por meio de uma percepção e de um desejo, os quais exigem um sujeito, dando passagem a um ser-no-mundo - presença intencional - que supera o mero estar-no-mundo - presença natural (VAZ, 1998, p. 188). Nas palavras do filósofo brasileiro:

O domínio do psíquico é, pois, o domínio onde começa o homem interior, e onde começa a, delinear-se o centro dessa interioridade, ou seja, a consciência.

$[\ldots]$

No nível do psíquico, o espaço-tempo é submetido a um movimento de interiorização: a origem de suas coordenadas não é mais o corpo, situado na exterioridade do mundo, mas o Eu que emerge como polo do mundo interior (VAZ, 1998, p. 188-189).

A nosso ver, a constante referência a um sujeito portador de interioridade indica que Henrique Vaz tenta defender-se contra um redutivismo materialista ${ }^{3}$. Por outro lado, o filósofo brasileiro busca soluções alternativas àquelas de índole dualista e, por isso, pensa a categoria do psiquismo como um intermediário unificador entre o corpo e o espírito. Segundo suas próprias palavras: “o eidos do psiquismo se define por esta posição mediadora entre a presença imediata no mundo pelo 'corpo próprio' e a interioridade absoluta - ou a presença de si a si mesmo, pelo espírito" (VAZ, 1998, p. 193). A categoria do psiquismo se apresentaria, portanto, como o primeiro momento da presença mediata do homem no mundo e como primeiro momento da presença do homem a si mesmo, no qual ocorre a unificação de "vivências, estados e comportamentos" (VAZ, 1998, p. 194), ou seja, todas as experiências do homem em sua presença intencional no mundo são interpretadas e tidas como experiências de um "eu".

Pode-se vislumbrar aqui uma semelhança com aquele eu psicológico, que Hume supôs ao explicar a paixão do orgulho e ao estabelecer a simpatia como fundamento das

\footnotetext{
${ }^{3}$ Entendemos por redutivismo materialista qualquer imagem do homem que negue nele a presença de alguma realidade imaterial. Nesse sentido, o pensamento e a liberdade, duas faculdades que tradicionalmente se atribui ao espírito, não passariam de funções orgânicas. Nessa concepção, o homem não passaria de uma substância única constituída por um aglomerado de moléculas. Tal concepção aparece bem sintetizada por um dos descobridores da estrutura da molécula de DNA: "A hipótese espantosa é que 'você' - as suas alegrias e tristezas, as suas memórias e ambições, o seu senso de identidade pessoal e livre arbítrio -, com efeito, não é nada mais que o comportamento de uma vasta reunião de células nervosas e suas moléculas associadas." (CRICK, 1995, p. 3 apud SMITH, 2014, p. 135).
} 
relações sociais e ao qual negou uma identidade ontológica no Livro 1 do Tratado. A diferença é que Henrique Vaz entende a categoria do psiquismo como insuficiente para fornecer uma explicação unitária e final da identidade humana e, portanto, não ontologicamente sustentável, devendo ser superada e suprassumida na categoria do espírito, responsável pela unificação da "exterioridade do corpo e da interioridade do psíquico na ‘identidade na diferença' [...] que irá caracterizar o noético ou espiritual” (VAZ, 1998, p. 195).

Se, por um lado, para Henrique Vaz, a categoria do psiquismo é insuficiente para explicar o fenômeno humano em sua totalidade, por outro é necessária para se evitar as diferentes formas de concepção dualista acerca do homem. Em consequencia, o filósofo brasileiro defende a dualidade ${ }^{4}$ entre o somático e o noético através do psíquico como uma alternativa que supere o monismo materialista e o dualismo: "Desde o início, pois, de nossa reflexão sobre o psíquico ele aparece como situado numa posição mediadora entre o corporal e o espiritual." (VAZ, 1998, p. 187).

A insuficiência da categoria do psiquismo se manifesta na incapacidade de articulação entre a exterioridade corporal e a interioridade psíquica, senão por meio de outra categoria que as possa abarcar e unificar. Ademais, a identidade e unidade do eu psicológico é continuamente ameaçada pela atuação do inconsciente, que "assenta numa dimensão que não é alcançada pela unificação consciente do mundo interior [e que se manifesta na] experiência de estados sobre os quais cessa ou se atenua a unificação consciencial do Eu, como, por exemplo, o estado onírico e os estados paranormais." (VAZ, 1998, p. 189). Por fim, o caráter egocêntrico do mundo interior do psiquismo também revela os limites da categoria do psiquismo para abarcar numa síntese final o fenômeno humano. Tal egocentrismo se manifesta no fluxo contínuo de memórias, representações e emoções, as quais são inevitavelmente juízos ou reações que levam em conta a inafastável referência dos objetos captados na exterioridade corporal aos interesses do próprio sujeito dessas diversas formas de percepção (VAZ, 1998, p. 193). Ora, o ser humano é capaz de se relacionar objetivamente com a realidade a sua volta, ainda que esta não represente para ele uma ameaça ou uma

\footnotetext{
${ }^{4}$ Utilizamos as palavras dualismo e dualidade para ilustrarem concepções diferentes a respeito das relações entre corpo e alma. Por dualidade, designamos a concepção segundo a qual o corpo e a alma são entendidos como coprincípios mutuamente dependentes na constituição de qualquer ser vivo. Sem a alma, que é a forma do corpo, não se pode falar num corpo, mas sim numa mera aglutinação de elementos tendentes à separação e corrupção. Poderíamos aplicar essa concepção ao homem definindo-o como corpo inteligente ou inteligência corporizada, conforme propôs Stork (2005, p. 32).
} 
vantagem. Essa capacidade que o ser humano tem de transcender sua situação no mundo e captar a realidade exterior em si mesma aponta para a existência nele de uma dimensão superior aos estritos limites dos interesses do mundo psíquico. Tal capacidade se manifesta, por exemplo, na capacidade de filosofar e fazer ciência (VAZ, 1998, p. 205).

Vemos despontar aqui a terceira e última dimensão da constituição formal do ser do homem, expressa pela categoria do espírito, na qual temos, a nível estrutural, "o ápice da unidade do ser humano", a partir do qual este "abre-se necessariamente para a transcendencia" (VAZ, 1998, p. 201).

Tal abertura se manifesta na capacidade que somente a espécie humana possui de captar os entes reais em si mesmos, em sua condição de objetos, com independencia da vantagem ou desvantagem que estes representem para a sua situação orgânica. Em outras palavras, somente o homem consegue pensar num objeto de maneira desinteressada, transcendendo suas próprias necessidades biológicas, tal como as considerações científicas a respeito da constituição molecular da água em dois átomos de hidrogênio e um de oxigênio, estão para além da aferição de sua potabilidade e capacidade de saciar a sede, horizontes nos quais se confinam as estimativas feitas, por exemplo, pelos outros mamíferos (ARREGUI; CHOZA, 1995, p. 281).

É o que Max Scheler expressou quando afirmara que para o animal não há objetos, mas apenas centros de resistência aos quais se dirigem seus impulsos e afetos:

\footnotetext{
O animal vive estático em seu mundo ambiente, que carrega estruturado consigo mesmo onde quer que vá, como o caracol com sua casa. $\mathrm{O}$ animal não pode levar a cabo esse peculiar afastamento e substantivação que converte um meio em mundo, nem tampouco a transfomação em objeto dos centros de resistência definidos afetiva e impulsivamente. Eu diria que o animal está essencialmente incrustado e absorvido pela realidade vital correspondente a seus estados orgânicos, sem apreendê-los nunca objetivamente. (SCHELER, 1970, apud ARREGUI; CHOZA, 1995, p. 281-282).
}

Correlativa à capacidade que o homem tem de captar a realidade em si mesma, transcendendo os próprios interesses biológicos, é a captação de si mesmo como objeto, isto é, a reflexidade, da qual nasce a subjetividade. Tal reflexividade permite ao homem modelar livremente sua própria vida (ARREGUI; CHOZA, 1995, p. 282).

Ou seja, essa capacidade que o homem possui de abrir-se à totalidade do real, bem como refletir sobre si mesmo, que o tornam um ser para a transcendência, somente pode ser compreendida a partir da categoria do espírito, na qual se tocam a antropologia filosófica e a metafísica. 
Em sentido metafísico, a noção de espírito é homóloga e coextensiva à noção de Ser, contendo as propriedades transcendentais de unidade, verdade e bondade. Nas palavras do filósofo brasileiro: "O espírito é, segundo a terminologia clássica, uma perfectio simplex- em si mesmo, atualidade infinita de ser. Por isso mesmo, é pelo espírito que o homem participa do Infinito ou tem indelevelmente gravada em seu ser a marca do Infinito." (VAZ, 1998, p. 202). Ao definir o espírito como atualidade infinita de ser, Henrique Vaz lhe parece atribuir aquelas características apontadas por Parmênides, tais como eternidade; imutabilidade; ilimitação e indivisibilidade. Em outras palavras, ser espírito e Ser Absoluto são sinônimos no pensamento do filósofo brasileiro.

Já no sentido antropológico, essa categoria adquire a individualidade e limitação próprias da estrutura psicossomática por ela informada. E é em razão dessa limitação, que Henrique Vaz entende que a noção de espírito reside propriamente na Metafísica, cabendo à Antropologia utilizá-la num sentido participado por analogia de atribuição ${ }^{5}$ (VAZ, 1998, p. 202).

Henrique Vaz (1998, p. 203, 209-212) destaca quatro traços fundamentais da experiência humana enquanto vivência espiritual, expressados na tradição filosófica por meio de quatro palavras: pneûma, noûs, logos e synesis. Cada um desses aspectos pode ser compreendido numa dimensão transcendental - metafísica - e numa dimensão categorial antropológica - conforme expõe o filósofo brasileiro:

A categoria do espírito no homem ou a estrutura noético-pneumática de seu ser é
atravessada pela tensão entre o categorial e o transcendental, entre o nível conceptual
da afirmação do homem como espírito e o nível conceitual da afirmação da
transcendência do espírito sobre o homem. [...]. Essa transcendência ou
transcendentalidade (no sentido clássico) do espírito é a origem das dificuldades que
se apresentam para a elaboração, no nível antropológico, da categoria de espírito.
Com efeito, essa elaboração deve levar em conta seja a dimensão transcendental (no
sentido clássico), seja a transposição categorial do conceito. [...] [É esse]
entrelaçamento entre as dimensões transcendental e categorial [...] que nos permite
alcançar o núcleo conceitual da noção de espírito. (VAZ, 1998, p. 208-209).

Como pneûma, se destaca o aspecto do espírito enquanto fonte de vida, entendida no sentido de movimento imanente, transcendendo o simples aspecto biológico para significar primeiramente a noção aristotélica de ato - enérgeia - abarcando assim a forma imaterial de

\footnotetext{
${ }^{5}$ Por analogia, entende-se comumente a aplicação de um mesmo nome a muitas entidades distintas, segundo uma semelhança e comparação por proporção. A analogia de atribuição ocorre quando uma perfeição encontra-se de modo próprio e num sentido pleno num ser e derivado e parcial nos demais.
} 
vida do Espírito Absoluto em sua relação de autoidentidade. No sentido mais antropológico que Henrique Vaz chama 'dimensão categorial do espírito finito' - a vida se manifesta num espaço interior, imanente, no qual se dá a relação e distinção real entre sujeito e objeto.

É interessante notar o paralelo dessa compreensão da vida humana como um espaço imanente na Antropologia Filosófica de Henrique Vaz com a concepção da pessoa como um ser portador de intimidade, presente nas reflexões de Ricardo Stork. A nosso ver, esse paralelo nos permite compreender melhor o sentido singular de imanência da vida humana no pensamento do filósofo brasileiro.

Por intimidade, Stork entende aquele grau de vida somente possível no nível do espírito, no qual subsiste um mundo interior somente conhecível pelo próprio sujeito e marcado pela unicidade e irrepetibilidade, sendo fonte emanadora de constantes novidades:

\footnotetext{
Esse mundo interior tem uma característica muito importante: é um mundo que não tem paralelo; quer dizer, é único, irrepetível.

[...]

Cada ser humano ocupa um posto no cosmos que somente ele pode preencher. Esse caráter de unicidade e irrepetibilidade se descobre na intimidade, em seu mundo interior. E essa intimidade é um dentro vivo. A intimidade não é uma coisa estática, imóvel, pois tem um certo caráter que me atreveria a chamar fontanal. Muitas vezes estou tentado a comparar a pessoa humana a uma fonte, a um manancial: alguém que surge, que brota e renova irrigando seu entorno.

[...]

Da fonte surge o que antes não estava, por exemplo os sentimentos, pensamentos, anelos, desejos, sonhos; nela ocorre o novo (há ocorrências), posto que a intimidade pessoal é inventiva. A intimidade da pessoa é criativa e criadora, e, portanto, é fonte de novidades. $\mathrm{E}$ isso o constatamos diariamente: o homem (para o bem ou para o mal) é capaz de encher de coisas novas o seu entorno (STORK, 1997, p. 13, tradução nossa).
}

O segundo traço fundamental da experiência humana enquanto vivência espiritual é expresso pelo conceito de noûs, proveniente diretamente da especulação grega, vindo a significar atividade de contemplação - theoría, que a tradição latina traduziu para intellectus, revelando profundidade de visão: intus legere, capacidade de ler o que está dentro (VAZ, 1998, p. 203). Segundo Henrique Vaz (1998, p. 210), o conhecimento enquanto ato unificante do objeto inteligível com a inteligência conhecedora exige a noção de espírito, tendo em vista que somente essa, em seu caráter imaterial, consegue tornar possível a unidade - do ato de conhecimento - na diferença - entre o objeto e o sujeito. Com efeito, posta de lado a noção de espírito, restaria sem explicação uma concepção realista a respeito do modo como se efetiva a posse intencional da ideia conhecida proveniente das coisas pela inteligência conhecedora, sem que tal posse desfigure a realidade mesma das coisas. Ou seja, sem a noção de 
inteligência espiritual, restam duas atitudes: o ceticismo empirista radical dos que negam um conhecimento para além do fluxo das sensações ou o idealismo dos que reduzem a realidade à projeção de ideias concebidas por uma inteligência criadora.

O terceiro aspecto da categoria do espírito é expresso pelo conceito de logos, significando na tradição filosófica a ordem universal e o princípio de inteligibilidade do ser. Nas palavras de Henrique Vaz: “A noção de espírito como logos mostra, assim, sua dimensão transcendental enquanto pensada como noção do Espírito infinito, princípio de toda inteligibilidade e, por conseguinte, princípio absoluto da distinção e ordem dos seres." (1998, p. 211). Em outros termos, para Henrique Vaz, ser é ser pensado. Mas isso não deve ser entendido num sentido imanentista e idealista, mas sim na esteira do realismo aristotélicotomista, visto que o filósofo brasileiro distingue os sentidos transcendental e categorial do espírito enquanto logos. Dessa forma, distingue o Logos do Espírito infinito criador e mensurante da inteligibilidade dos seres - sentido transcendental - do logos do espírito finito - sentido categorial - mensurado por essa mesma ordem de inteligibilidade.

O quarto e último aspecto da categoria do espírito vem expresso na tradição filosófica pelo termo synesis, significando a reflexividade do espírito como consciência-de-si, tema já presente nas especulações socráticas e trabalhado na antiguidade clássica, na filosofia medieval e tornando-se tema dominante da filosofia moderna, em grande parte dedicada à filosofia da subjetividade (VAZ, 1998, p. 203-204). A dimensão transcendental da synesis consiste no conhecimento total que o Espírito Absoluto possui de si, numa identidade total entre Inteligência e Inteligível, encontrando, na metafísica de Aristóteles, sua mais célebre formulação:

... o pensamento que é pensamento por si, tem como objeto o que por si é mais
excelente, e o pensamento que é assim maximamente tem como objeto o que é
excelente em máximo grau. A inteligência pensa a si mesma, captando-se como
inteligível: de fato, ela é inteligível ao intuir e ao pensar a si mesma, de modo a
coincidirem inteligência e inteligível [...] o que de divino há na inteligência é essa
posse... Se, portanto, nessa feliz condição em que às vezes nos encontramos, Deus se
encontra perenemente, isso nos enche de maravilha; e se Ele se encontra numa
condição superior, é ainda mais maravilhoso. E Ele se encontra efetivamente nessa
condição. E Ele também é vida, porque a atividade da inteligência é vida, e Ele é,
justamente, essa atividade. E sua atividade, subsistente por si, é vida ótima e eterna.
Dizemos, com efeito, que Deus é vivente, eterno e ótimo; de modo que a Deus
pertence uma vida perenemente contínua e eterna: isto, portanto, é Deus (Metafísica,
Livro $12,1072 b 20$ apud REALE, 2005, p. 565).

A dimensão categorial da synesis consiste na reflexão que o espírito finito faz de si, a partir do contato com as realidades objetivas do mundo e com as realidades subjetivas da 
pluralidade de consciências-de-si. Desta forma, o espírito finito primeiro descobre a existência de diferentes realidades para além da sua subjetividade e somente depois se descobre como sujeito idêntico a si, num movimento dialético de identidade na diferença (VAZ, 1998, p. 212).

Após apontar esses quatro traços fundamentais que compõe o conceito de espírito, Henrique Vaz descreve a estrutura dessa categoria como o cruzamento de duas intencionalidades: a inteligência e a vontade, tendendo para a verdade e a bondade do ser, respectivamente. Ora, tais tendências revelam haver no homem uma abertura e uma inclinação à infinitude do ser, fazendo gerar em seu interior uma tensão: por um lado tende à Verdade e ao Bem em sua universalidade, por outro, somente consegue, em seus atos concretos, captar a verdade particular e escolher o bem finito. Tal limitação provém de sua presença no mundo, ligada necessariamente a uma individualizada estrutura psicossomática (VAZ, 1998, p. 217).

Ora, é justamente em virtude dessa tensão, que o homem, impulsionado pela dinâmica do seu espírito, movimenta-se num contínuo processo de realização, rumo à verdade e ao bem universal, possuídos apenas intencionalmente. E, é essa posse meramente formal que diferencia o espírito no homem, do espírito em sua transcendentalidade pura, coextensiva à universalidade do ser (VAZ, 1998, p. 223).

Tais intencionalidades do espírito no homem - abertura à Verdade e tendência ao Bem - provocam em seu interior um movimento de abertura, no qual está contido o acolhimento e a saída rumo ao ser. Tal movimento é chamado por Henrique Vaz (1998, p. 220) de regiratio ou circulatio, e manifesta a unidade da forma espiritual na dualidade de faculdades. Com efeito, a inteligência e a vontade se compenetram reciprocamente, constituindo o que o filósofo brasileiro denominou o quiasmo do espírito finito (VAZ, 1998, p. 212-213).

Restam assim delineadas as três categorias básicas que compõem a estrutura humana. Antes de prosseguir para as categorias que compõem as relações do homem, façamos uma breve consideração a respeito da teoria hilemórfica de Aristóteles, a fim de esclarecer melhor como se entrelaçam as categorias de estrutura e a atualidade desse tipo de reflexão. 


\subsection{A teoria hilemórfica e a superação do dualismo}

Para compreendermos como Henrique Vaz afirma a presença do espírito no homem sem recorrer às concepções de tipo dualista, entendemos ser importante compreender o sentido da psyché aristotélica, do qual o filósofo brasileiro parece partilhar:

\footnotetext{
A dialética do espírito mostra, pois, que a unidade estrutural corpo-psiquismoespírito é uma unidade segundo a forma - correspondendo à forma aristotélica, psyché ou anima-, que deve realizar-se na relação dinâmica e ativa do homem com a universalidade do ser. (VAZ, 1998, p. 223).
}

Com efeito, Aristóteles também buscou, através da sua teoria hilemórfica, escapar ao dualismo platônico, sem recair num fisicalismo materialista. E, visando entender melhor esse aspecto do pensamento do filósofo grego, passemos a analisar as explicações acerca da psyché (psique) dadas por J. Arregui e J. Choza, autores que estabelecem uma ligação entre as noções antropológicas fundamentais do aristotelismo e algumas questões postas pela ciência contemporânea.

Primeiramente, faz-se necessário uma breve ressalva. Apesar de utilizar três categorias (corpo, psiquismo e espírito) para exprimir a estrutura do homem, não se pode deduzir que Henrique Vaz tenha assumido o esquema trial - corpo/alma/espírito - ao invés do dual - corpo/alma. Isso porque, ao afirmar as duas possibilidades de compreensão do homem na tradição filosófica (VAZ, 2009, p. 168), não optou explícita e exclusivamente por uma das duas, sendo-nos permitido supor que as duas concepções podem até mesmo ser conciliáveis, dependendo do sentido em que se compreende o conceito de alma.

Ademais, em razão da proposta de Henrique Vaz de releitura do pensamento de Tomás de Aquino para compreensão das raízes da Modernidade e para superação de sua intrínseca tendência nihilista (OLIVEIRA, C., 2013, p. 134), podemos supor que ele também assume a teoria hilemórfica de Aristóteles - matéria/forma - entendendo, todavia, que a forma, no caso do ser humano, assume, além das funções vegetativas e sensitivas, as funções intelectivas, sendo que, enquanto espírito, a forma pode subsistir separada da matéria, conforme veremos mais adiante.

Pois bem, feita a referida ressalva, passemos a uma breve análise da teoria hilemórfica de Aristóteles. Para o Estagirita, o que diferencia os seres vivos dos seres inanimados é a presença da psique - alma, que no pensamento do filósofo grego, não designa 
propriamente a reflexividade do intelecto nem o âmbito da intimidade e privacidade da consciência, possuindo antes uma dimensão de princípio biológico. Aristóteles define alma como "a atualidade primeira de um corpo natural orgânico" (Sobre a Alma II, 1: 412a 3413a10 apud ARREGUI; CHOZA, 1995, p. 83), o que significa dizer que a alma é entendida enquanto ato do corpo vivo e não como uma substância justaposta ou acrescida ao corpo. Dessa forma, a alma não é um elemento que se acresce ao corpo, assim como também não pode ser reduzida a um de seus componentes orgânicos. Visando esclarecer sua concepção, Aristóteles (Sobre a Alma II, 1: 412b 17-25 apud ARREGUI; CHOZA, 1995, p. 84) estabelece uma analogia com a distinção entre o olho e a visão: se o corpo fosse o olho, a alma seria o ato do olho, ou seja, a visão. Assim, conforme sintetizam Arregui e Choza "a alma se compara ao corpo como o determinante com o determinado, ou o unificante com o unificado, quer dizer, como o ato com a potência" (1995, p. 85).

Além de não dualista, a visão de Aristóteles acerca do homem ou de qualquer ser vivo também está longe de qualquer forma de fisicalismo, uma vez que a mera composição material não seria o elemento de distinção entre os seres animados e os seres inanimados. Seria necessário também levar em conta o modo como essa composição material é estabelecida, isto é, as leis ou propriedades da matéria assinaladas pela forma, cuja espécie é distinta nos seres vivos e nos seres inertes, ainda que a composição material seja bem semelhante entre os mesmos.

A psique aristótelica é uma especificação do gênero forma, o qual, por sua vez, combinado com a matéria, compõe a essência de qualquer ente material. A psique ou alma é a forma específica dos seres materiais viventes. O conceito de forma - morphé, em Aristóteles, possui uma função instrumental: a forma organiza um conjunto de elementos em torno a determinado fim que os unifica. Para tornar mais claro o alcance desse conceito tão presente na filosofia clássica e medieval, Arregui e Choza (1995, p. 99-101) o identificam com os conceitos atuais de Gestalt e pattern. O primeiro deles surgiu na psicologia alemã e está relacionado ao ato de percepção imediata de uma configuração significativa. O exemplo mais frequente para se ilustrar o reconhecimento dessa configuração é o da melodia musical, que pode ser mantida e reconhecida, ainda que haja uma profunda alteração em seus elementos (timbre dos sons, ritmo etc.). O segundo conceito é de origem anglossaxônica e também denota configuração significativa, mas com um caráter reprodutivo, no sentido de matriz geradora de um padrão. 
Embora não sejam elementos justapostos, há certa independência da forma em relação à matéria, independência essa que cresce dos seres inertes para os seres vivos e, dentre esses, culmina no homem, único ser material dotado de vida intencional. Poderíamos, portanto, falar em três graus de formalização. Nos seres inertes, é um pouco mais difícil visualizar essa independência da forma com relação à matéria, mas podemos imaginar alguns casos que tornam essa relativa independência um pouco mais visível, como é o caso de uma cachoeira ou de uma onda no mar, nas quais as configurações significativas permanecem constantes apesar do contínuo fluxo de moléculas de matéria que se sucedem (ARREGUI; CHOZA, 1995, p. 100).

Nos seres vivos, a identidade da forma é mais intensa, a ponto de admitir uma espécie de autorregulação, que mantém o equilíbrio interno do ser vivo em meio a diversas formas de intercâmbio material com o meio. Quanto a essa capacidade, podemos chamá-la analogicamente de homeostase, própria dos seres vivos, que se apresentam como sistemas abertos autorregulados. Ou seja, o organismo vivo mantém um padrão de identidade em si mesmo e com capacidade de se transmitir aos seus descendentes, apesar das constantes mudanças em seus elementos materiais (ARREGUI; CHOZA, 1995, p. 101).

Uma questão interessante seria como situar os sistemas cibernéticos nessa classificação. Eles teriam uma forma? Se sim, no que esta se diferenciaria da forma de um ser vivo, já que existem máquinas capazes de autorregulação dos seus próprios sistemas em função de variáveis externas?

De certa maneira, o embrião dessa discussão já estava presente na filosofia grega. Com efeito, o próprio Platão utilizou o termo que deu origem à cibernética (kybernetiké - a arte de governar a nave) para designar as funções e atividades da psyché. A natureza desse piloto (kybernétes) seria a mesma das ideias (eidos), ou seja, gozaria de uma independencia da estrutura material da qual inerisse. O interessante é que tal entendimento apresenta um grande paralelo com a concepção de sistemas cibernéticos proposta por Nobert Weiner e K. Steinbuch, dois dos maiores representantes dessa ciência. Com efeito, os referidos cientistas entendiam que a cibernética não se ocupa propriamente dos componentes materias que constituem as estruturas informáticas, mas sim das funções lógico-matemáticas responsáveis pela autorregulação. Ou seja, a cibernética se ocupa mais da idealidade do que da materialidade dos seus objetos (ARREGUI; CHOZA, 1995, p. 119-120).

Pois bem, levando em conta que Aristóteles criticou o eidos platônico e o substituiu pela noção de forma, que inclui em si o caráter ativo responsável por levar à 
plenitude determinado ente para que o mesmo possa atingir o seu fim, podemos identificar a diferença formal entre um ser vivo e um ser artificial: a presença do caráter ativo de sua própria forma, a qual contém intrinsecamente a energia necessária para pôr a sua própria estabilidade. Em contrapartida, uma máquina só subsiste funcionando quando à sua estrutura material e à sua programação ideal é acrescida extrinsecamente uma quantidade de energia suficiente para que aquela máquina realize suas operações. Nas palavras de Arregui e Choza:

\begin{abstract}
Agora resta compreensível que a diferença entre a máquina e o organismo vivente não reside principalmente nas funções: não consiste em que a máquina não tenha imaginação, memória, capacidade fazer juízos de valor, etc., porque as tem, na medida em que pode realizar funções imaginativas, memorativas, valoritivas, etc. $\mathrm{O}$ que a máquina não tem é um corpo, porque não tem psique [ato primeiro do corpo físico organizado]: não é uma estrutura funcional dotada de energia suficiente para realizar-se autonomamente. Uma máquina não tem corpo, porque nela não há um copertencimento intrínseco entre forma, energia e elementos materiais, mas sim que os elementos materiais [todos são cambiáveis] são acrescidos a um projeto ideal, que não possui a energia para pôr sua própria estabilidade, sua própria realização. Desde esse ponto de vista, por não ter um corpo, se pode dizer que uma máquina é mais imaterial e menos real do que um organismo vivente, que é mais intencional e menos material do que um ser vivo: é, justamente, uma idealidade materializada ou positivada (ARREGUI; CHOZA, 1995, p. 123-124, tradução nossa).
\end{abstract}

O caráter ativo das formas dos seres vivos se manifesta também na fecundidade da sua vida e na sua mortalidade. Diferente de uma máquina, cujo objetivo máximo do sistema é sua própria manutenção, a vida é fecundidade, tendendo sempre a crescer e se expandir. E, diferente dos seres vivos, as máquinas não são capazes de morrer, tendo em vista que sua unidade não é intrínseca (naquele sentido de co-pertença a que aludimos acima), e, portanto, não pode romper-se (ARREGUI; CHOZA, 1995, p. 124).

Estabelecidos os princípios na filosofia aristotélica pelos quais percebemos as diferenças entre as formas dos seres vivos, dos seres inertes e das máquinas, passemos a destacar a especificidade da forma humana dentre os outros seres vivos, única dotada de uma singular capacidade cognitiva.

No ser humano, a forma atinge um grau mais intenso, não sendo somente o ato do corpo, mas também configurando outras formas, por meio da atividade cognoscitiva, cujo termo é a posse intencional de outra forma. Essa formalização operada no ato de conhecimento é diferente da formalização da matéria na constituição do ser humano vivo, pois nesta há um efeito real, enquanto naquela o efeito é meramente intencional, isto é, a formalização de algum objeto de conhecimento não altera em nada suas propriedades (ARREGUI; CHOZA, 1995, p. 102). 
A formalização de um objeto de conhecimento dá-se no ato de pensar e é justamente este ato que revela a singularidade da forma humana, a única na natureza que contém uma faculdade não orgânica, ou seja, na qual se dá uma ação que transcende o âmbito do físico e do biológico.

Aristóteles atribuiu o pensamento ao intelecto, uma faculdade com caráter divino (ARISTÓTELES, Ética a Nicômacos, Livro X, 1177a), na medida em que suas ações superam o âmbito da temporalidade e as limitações da materialidade.

Tomás de Aquino unirá a teoria hilemórfica de Aristóteles com a tese da imortalidade da alma em Platão para defender que a forma humana é de natureza espiritual, subsistindo após a morte, mas não preexistindo ao corpo. Por sua vez, Henrique Vaz (2009, p. 189) seguirá essa posição, defendendo com Aristóteles e Tomás de Aquino que a presença do espírito no homem se evidencia pelo pensamento.

Esse caráter não orgânico do intelecto se revela na sua infinitude, na medida em que permite uma abertura à totalidade do real, não condicionando o homem a se deter apenas nos objetos enquanto diretamente relacionados às suas necessidades vitais, conforme já pudemos destacar no subcapítulo anterior. E outro traço correlato ao antecedente é a capacidade reflexiva do intelecto, do qual também já falamos antes.

Por fim, uma terceira característica que denota a imaterialidade do pensamento é seu caráter simultâneo e não cronometrável. Com efeito, é possível dizer que um juízo não pode ser decomposto em seus elementos separadamente, sem que se perca o significado do próprio juízo. Como exemplo dessa necessidade de simultaneidade presente em nossos juízos, Peter Geach analisou a seguinte afirmação: "todos os tigres são perigosos”. Tal juízo não foi construído mentalmente a partir da junção sucessiva de seus elementos, ou seja, não se trata de uma consideração sobre todos os tigres, seguida de um pensamento sobre o perigo. Esse juízo somente tem significado se todos os seus elementos estão simultaneamente presentes por quem o enuncia. Também no caso de um juízo do tipo geométrico, tal como pensar que o triângulo é uma forma geométrica na qual a soma dos ângulos internos é 180 graus, há uma simultaneidade entre o sujeito e o predicado, não havendo, portanto, qualquer espécie de sucessão, nem de duração temporal. Dessa forma, em razão de seu caráter não cronometrável, resta claro que o pensamento não pode ser uma atividade orgânica distendida temporalmente, como é próprio das realidades pertencentes ao âmbito material (GEACH, 1981 apud ARREGUI; CHOZA, 1995, p. 283). 
Assim como o pensamento, o ato pelo qual a forma atualiza um corpo, seja no caso de um ser humano ou de qualquer espécie de ser vivo, não é de natureza processual, no sentido de não ser redutível a uma sequência de operações ordenadas num intervalo de tempo. Em outras palavras, não há um paralelismo entre os processos físico-químicos e a constituição formal de um ser vivo, na medida em que o paradigma mecanicista não se aplica às dimensões formais da realidade.

Para entender melhor o caráter imaterial do ato da forma, tenhamos em conta o que Aristóteles considerava matéria, tendo em vista que a noção de imaterial se torna mais clara a partir da negação da materialidade. Para o Estagirita, o conceito de matéria está ligado ao de potência (dynamis) e, por ser desprovido de determinação - ato - é muito difícil de ser pensado. A matéria pura seria um intermediário entre algo (matéria já determinada por uma forma específica) e o nada. Outra noção básica seria considerar a matéria como o primeiro sujeito passivo ${ }^{6}$. Ao receber uma forma, a matéria originária torna-se matéria provida de quantidade, constituída de "partes extra partes" - partes fora de partes, ou seja, partes distendidas no espaço e no tempo. À primeira vista, parece ser esse também o significado de matéria em Descartes, que a concebia como pura extensão - res extensa. Esse caráter potencial manifestado na distenção espaçotemporal é o que permite a presença do devir mudança - na estrutura das coisas (ARREGUI; CHOZA, 1995, p. 102-103).

Um ser imaterial seria um ser desprovido do devir próprio da matéria e, portanto, sua constituição ontológica prescindiria de uma sequência de etapas distendidas no espaço e no tempo. Essa imaterialidade é uma característica constante em todos os atos de formalização dos seres vivos, podendo ser mais bem compreendida a partir dessa negação da distenção espaçotemporal, conforme expõem Arregui e Choza:

\footnotetext{
${ }^{6}$ Apesar de se tratarem de campos epistêmicos distintos, o conceito filosófico de matéria concebido na filosofia antiga não se afasta dos modelos teóricos propostos pela física moderna. Exemplo disso é a mudança, a partir do surgimento das teorias quânticas, na concepção das leis da natureza, entendidas como não determinadoras da ocorrência de um evento, mas sim da probabilidade de ocorrência do mesmo, obedecendo a uma equação de onda que pode ser expressa matematicamente. Na opinião de Heisenberg, tais concepções teóricas não são mais do que uma "formulação quantitativa do conceito de dynamis, possibilidade, [que] na filosofia de Aristóteles [... significa] meio caminho entre a realidade maciça da matéria e a realidade intelectual da idéia ou imagem." (HEISENBERG, W. et al. Problemas da Física Moderna. São Paulo: Perspectiva, 2000 apud PETRÔNIO, 2008, p. 75). Em outras palavras, conforme esclarece Petrônio: “A concepção de que os eventos não estão determinados de modo peremptório, mas que a possibilidade ou a 'tendência' para que um evento ocorra apresenta uma espécie de realidade - uma certa camada intermediária de realidade, meio caminho entre a realidade maciça da matéria e a realidade intelectual da ideia ou a imagem - este conceito desempenha um papel decisivo na filosofia aristotélica. Na teoria quântica moderna, tal conceito assume nova forma; é formulado quantitativamente como probabilidade e sujeito a leis da natureza que são expressas matematicamente. As leis da
} 
Se um ser é já $a b$ initio tudo o que pode ser, então não há para ele devir, distenção, processo: não há para ele umas partes fora de outras nem umas após as outras: não há para ele espaço nem tempo, ou seja, o espaço e o tempo lhe são extrínsecos e não lhe afetariam; seria, justamente por isso, imaterial.

[...]

O âmbito do físico é aquele no qual tem lugar processos de velocidade finita, e a noção de velocidade finita é, precisamente, a noção de distenção espaçotemporal.

Como é óbvio, todos os processos de velocidade finita se podem medir [...] Mas se houvesse algum processo de velocidade infinita não duraria, não tardaria: não haveria tempo desde que começasse até que terminasse, senão que seu começo e seu término, a ação e seu resultado, seriam estritamente simultâneos. Quer dizer, um processo de velocidade infinita já não é um processo, seria mais uma espécie de operação ou atividade não processual [...]

Isto não tem, em si mesmo, nenhum sentido físico. Pois bem, assim é caracterizado o imaterial por Aristóteles, Descartes e Hegel e assim é como, em geral, se forma negativamente a noção do imaterial: aquilo que não está distendido espaçotemporalmente. (ARREGUI; CHOZA, 1995, p. 104).

É interessante notar que a mesma concepção do imaterial encontra-se presente em Henrique Vaz, ao tratar da natureza do ato espiritual: "o ato espiritual é absoluta simplicidade, ou seja, não é estendido ou divisível no espaço e se exerce como intensidade transtemporal, transcendendo o fluxo do tempo" (1998, p. 241).

A partir dessa contraposição aos processos materiais, podemos superar o paradigma mecanicista e compreender melhor a natureza imaterial da psique enquanto ato do corpo vivo. Assim, o ato de formalização de um ser vivo seria uma operação de velocidade infinita e tempo zero que constitui e coordena de maneira instantânea e simultânea todo o conjunto de elementos e processos materiais próprios daquele ser vivo. Assim como a vida, para Aristóteles há no ser humano outras atividades imateriais, que ele chama imanentes, que se caracterizam pela simultaneidade entre a ação e seu resultado, tais como a visão, a percepção ou qualquer ato de natureza cognitiva ${ }^{7}$. Nesse sentido, a ação de ver equivale a já

natureza formuladas em termos matemáticos não mais determinam os próprios fenômenos, mas a possibilidade de ocorrência, a probabilidade de que algo ocorrerá." (2011, p. 242-243).

${ }^{7}$ O problema da integração - binding problem - é um típico exemplo que, a nosso ver, aponta para a necessidade de uma concepção teórica que leve em conta o caráter simultâneo da percepção visual e de outros atos de natureza cognitiva. Tal problema consiste na "dificuldade de saber como o cérebro consegue reunir os distintos estímulos em uma percepção unificada do objeto. O córtex visual contém células e regiões que respondem a certas características dos objetos, como a cor, a forma e o movimento, as linhas e os ângulos, por exemplo. Porém, a visão de um objeto é sempre uma experiência unificada...” (MASSMANN, 2012, p. 60). Dessa forma, um ato cognitivo - seja na forma de um juízo, seja na forma de uma percepção visual de um objeto - não pode ser reduzido a um conjunto de operações algorítmicas, segundo um paradigma mecanicista. De acordo com Penrose, "nenhum sistema mecânico e baseado em regras pode explicar a capacidade criativa da mente" (HORGAN, 1999, p. 240 apud SMITH, 2014, p. 156). Nessa mesma linha, W. Smith, afirma que "as operações mais características da mente humana não são de fato algorítmicas" e, como exemplo desse tipo de operação menciona, citando Penrose, a habilidade que a 'mente matemática' tem de distinguir entre verdade e erro nas provas e descobertas matemáticas: "os algoritmos, em si mesmos, nunca determinam a verdade! [...] Precisam-se 
ter visto. E, em relação propriamente ao ato da psique, podemos dizer que é único e indivisível, não podendo ser reduzido a somatória das funções vitais orgânicas, tendo em vista que um ser vivo está vivo ainda que algumas dessas funções não estejam desempenhando atividades num determinado momento, como seria o exemplo de um ser humano em jejum, o qual possui vida tanto quanto durante o ato de comer (ARREGUI; CHOZA, 1995, p. 105).

Portanto, perante o exposto acima, acreditamos ter compreendido um pouco mais o significado da relação entre matéria e forma, bem como a natureza do ato de formalização da matéria. Esperamos que as considerações feitas possam ter tornado mais clara a atualidade da reflexão aristotélica, resgatada por Henrique Vaz através de Tomás de Aquino, além de terem servido para esclarecer a diferença existente entre concepções duais e dualistas do homem.

\subsection{As categorias de relação}

Para Henrique Vaz, a experiência fundamental da qual nasce a reflexão da antropologia filosófica é a experiência do homem enquanto sujeito. $\mathrm{O}$ homem é um ser que se interroga, não como subjetividade abstrata, mas como um ser finito e situado numa realidade, inserção essa expressa pelas diferentes formas de presença (corporal, psíquica e espiritual), descritas anteriormente nas categorias de estrutura. Por sua vez, as categorias de relação permitem ao homem preencher de conteúdo a sua estrutura formal, pois é a partir da experiência com a realidade na qual está imerso que o homem exprime a si mesmo e exprime a significação silenciosa que jaz nas coisas que o circundam. Essa experiência de dizer a si mesmo e dizer a realidade que o circunda faz do homem um ser de linguagem (VAZ, 1992, p. 9-11).

de intuições externas para decidir a validade ou a invalidade de um algoritmo [...]”. Portanto, diante de um possível caráter simultâneo da percepção e de outros atos de natureza cognitiva, podemos vislumbrar os limites de uma concepção exclusivamente materialista que reduza o ato cognitivo a uma função cerebral. O próprio Penrose admite os limites dos paradigmas físicos atuais e sugere a não localidade quântica - dentro de uma nova física que seja capaz de elaborar uma teoria quântica da gravidade - como futura solução para o problema da ligação. Já W. Smith busca a solução para tais limites numa abordagem metafísica que ultrapasse o domínio psicossomático e seja capaz de dar conta de funções não algorítimicas de ordem superior. (2014, p. 153, 156 e 164). 
É a partir dessa experiência como ser situado que Henrique Vaz criticará as concepções filosóficas de um sujeito puro, separado e independente da realidade. Com efeito, a partir da experiência que faz de si mesmo como sujeito que se interroga, que não é totalmente transparente a si mesmo, Henrique Vaz considerará que o homem não é apenas um ser-em-si, mas também essencialmente um ser-para. A capacidade de relação não seria algo acidental no homem, mas algo que pertence a sua própria constituição ontológica e, justamente através das relações que estabelece com o seu entorno, é que o homem se realiza e se entende como um ser finito e situado. Nas palavras do filósofo brasileiro:

... o homem é linguagem, ou é, essencialmente, movimento incessante de auto
exprimir-se conferindo, nessa auto expressão, uma significação propriamente
humana ao ser e à realidade na qual está situado. Essa é, pois, a estrutura do Cogito
ou do sujeito na Antropologia filosófica, a de ser essencialmente mediação entre a
Natureza e a Forma, não tendo nenhum sentido aqui a ficção de um Cogito solitário
e vazio, ou de um Cogito como primum logicum na ordem das razões, segundo a
instituição cartesiana do saber.
(...)
Trata-se agora de determinar o conteúdo dessa forma e é evidente que, em razão da
finitude do homem como ser situado - ou como ser no Ser - esse conteúdo advém ao
homem ab extra, não sendo ele o criador ou a fonte do Ser no qual é. Assim,
constituído estruturalmente por formas de expressão, o homem é, essencialmente,
relação com a realidade, à qual confere uma expressão humana (...). A passagem da
estrutura à relação é, por conseguinte, a passagem da forma ao conteúdo da
expressão ou, em termos de linguagem, do significante ao significado. (VAZ, 1992,
p. 11).

Essa relação com o entorno se dá de três modos, constituindo assim as três esferas de relação com a realidade que Henrique Vaz aponta: relação de objetividade, relação de intersubjetividade e relação de transcendência. A primeira delas surge quando o homem faz experiência de sua situação no espaço-tempo do mundo, a segunda na experiência com outros sujeitos situados e a terceira quando o homem percebe em si um excesso ontológico latente na abertura ilimitada à verdade e ao bem (VAZ, 1992, p. 14).

As categorias de relação apresentam-se como essenciais para compreendermos que o homem é um sujeito não absoluto e que se relaciona com a realidade extramental sem se confundir com ela. Passemos a argumentar nesse sentido, para depois analisarmos cada uma das três esferas de relação através das quais a estrutura humana, em seus três níveis, recebe seu conteúdo. 


\subsubsection{O homem como sujeito situado}

Para prosseguirmos na exposição das categorias de relação inerentes à vida humana, convém analisarmos dois pressupostos da filosofia de Henrique Vaz: a existência de um sujeito e sua condição de ente situado.

Conforme vimos na primeira parte do presente trabalho, David Hume entendia que a identidade pessoal não passa de uma ilusão e que, portanto, não haveria que se falar na existência de um sujeito permanente. Ora, negar a permanência de um sujeito é o mesmo que negar sua existência, uma vez que se reduzimos o homem a um feixe de percepções que se sucedem, dá no mesmo dizer que tais percepções não inerem em nada ou afirmar que tais percepções pertencem a algo cuja consistência ontológica não é minimamente durável conforme afirmado por Hume (2009, p. 285) na seguinte passagem, dentre outras: "Nela [na mente] não existe, propriamente falando, nem simplicidade em um momento, nem identidade ao longo de momentos diferentes". Com efeito, sem a permanência de um sujeito, não se pode atribuir qualquer relação de pertença entre uma percepção e esse mesmo sujeito, pois qualquer forma de relação exige a permanência dos polos relacionados, sob pena de afirmarmos e negarmos simultaneamente a existência da própria relação de pertença.

Por sua vez, negar a existência do sujeito é, evidententemente, incorrer em contradição, uma vez que o ato de negar precisa ser feito por alguém - um sujeito. Portanto, podemos dizer que Hume se colocou num degrau metafísico para, a partir dessa privilegiada perspectiva, afirmar seu empirismo e, de modo incoerente, negar qualquer elemento de natureza metafísica, tais como a causalidade, os universais e as substâncias, e, dentro deste gênero, o sujeito.

E não somente $\mathrm{o}$ ato de negar, mas inclusive o ato cético de questionar a possibilidade do conhecimento da própria existência também supõe o uso da razão e da liberdade.

Finalmente, até mesmo a possibilidade do erro no juízo sobre a própria existência, que poderia ser fruto de uma ilusão, também supõe o exercício da razão e da liberdade, pois um sujeito ficcional necessitaria ser fruto da ilusão de alguém, ou seja, a raiz do equívoco é sempre íntima, não podendo ser externa ao próprio sujeito, vez que o equívoco será sempre o equívoco de alguém. Em outras palavras, se o "eu pensado", bem como qualquer ideia fosse 
pura representação mental, dever-se-ia questionar o porquê de tal afirmação não ser também uma mera representação mental (SELLÉS, 2013, p. 35).

Enfim, esse tipo de inconsistência, típica de muitas filosofias empiristas, não escapou à crítica de Henrique Vaz, que destacou a impossibilidade do sujeito, enquanto razão e liberdade, negar a si próprio, sem incorrer em evidente contradição, na medida em que se utilizaria implicitamente de sua razão e de sua liberdade no próprio ato de negá-las:

\begin{abstract}
A aporética crítica, do ponto de vista tético, desemboca assim na impossibilidade radical de o homem não se autoafirmar como razão e liberdade, na medida em que se mostra como um ser que se interroga a si mesmo e, nessa interrogação, compreende sua própria estrutura racional e livre - ou sua estrutura espiritual. Recusar a interrogação ou, mais ainda, negar-se como razão e liberdade significaria, para o homem, uma contradição mortal instalada no âmago de seu ser: significaria a negação da razão e da liberdade no interior de seu próprio movimento de pôr-se absolutamente, o que constitui justamente o momento tético da aporética crítica do espírito. O argumento de redarguição ou elenktikôs [utilizado por Aristóteles no livro gamma da Metafísica para silenciar os negadores do princípio da não contradição] teria lugar aqui (...). Ousando essa negação o homem exila-se a si mesmo na mudez do vegetal (VAZ, 1998, p. 218).
\end{abstract}

Embora apresente essas críticas às filosofias que negam a existência do sujeito, Henrique Vaz não cai no outro extremo, que seria o de conceber o sujeito como uma pura substância pensante distinta e separável da corporeidade, com total independência das realidades extramentais para exercer seu ato de pensar, nos moldes da proposta cartesiana. A repulsa do filósofo brasileiro por essa posição já foi mencionada no subcapítulo anterior deste trabalho, cabendo-nos agora apenas reforçar esse rechaço com algumas colocações.

No modelo cartesiano, a única espécie de conhecimento imune à dúvida cética é a certeza do conhecimento do próprio ato de pensar, resultando dessa certeza a dedução de que o sujeito cartesiano é um puro sujeito de pensamento, no qual o ato de pensar possui por objeto o próprio pensamento, ou, nas palavras de Henrique Vaz, "um sujeito puro não tem necessidade de interrogar-se: ele é total transparência a si mesmo" (VAZ, 1992, p. 9). Dessa forma, na relação de conhecimento, haveria uma identidade entre sujeito e objeto.

Ocorre que, com exceção do Ser divino (conforme citamos passagem da Metafísica de Aristóteles no subcapítulo 2.2.1), não ocorre identidade perfeitamente equivalente entre o "eu pensante" e o "eu pensado", pois o "eu pensado" não pensa, vez que uma ideia não pode realizar o ato de pensar, assim como um sujeito pensado não pode exercer $\mathrm{o}$ ato de ser sujeito, pois também o sujeito pensado difere do sujeito real. Além disso, nosso autoconhecimento não pode ser inato, de outra forma existiria sempre, o que contradiz nossa 
própria experiência cotidiana, a partir da qual sabemos que no seio materno ou enquanto dormimos não temos conhecimento em ato, mas apenas potencialmente. Com efeito, caso nosso autoconhecimento fosse inato, seria sempre atual. Ademais, sendo inato, não seria adquirido e, portanto, não poderia evoluir, o que também é contrário a nossa experiência (SELLÉS, 2013, p. 23 e 29).

Talvez se pudesse alegar que o autoconhecimento, embora independente das coisas, não seria inato, pois se daria de modo reflexivo, o que admitiria a hipótese da aquisição desse tipo de conhecimento num determinado momento e até de sua possibilidade de progressão ao longo do tempo. Todavia, não podemos admitir tal concepção, vez que a mesma supõe que da ignorância - estado potencial prévio à reflexão sobre si, nasce o conhecimento - ato de reflexão sobre si, o que é absurdo, pois a potência não tem a primazia ontológica sobre o ato, sendo este sempre anterior à potência, pois algo não pode conferir a si mesmo uma perfeição que não tem. Ou, em outras palavras, o ato possui sempre uma prioridade causal em relação à potência, visto que nada atua senão enquanto estiver em ato, na medida em que agir é exercer um influxo sobre outro, o que somente se pode fazer caso se possua a perfeição que se quer comunicar. Portanto, não se pode passar da ignorância ao autoconhecimento sem a intervenção de algum ato exterior ao próprio sujeito.

Em síntese, podemos perceber que o conhecimento humano sempre se dá de modo dual: o ato de conhecer - o método, não se confunde com o objeto, seu tema. Não se pode falar num autoconhecimento inato ou independente das coisas, como o faz o cartesianismo, nem na negação de um sujeito na relação de conhecimento, como o faz o empirismo de Hume.

Por fim, uma alternativa que se poderia fazer às propostas cartesiana ou empirista seria incluir o sujeito e o objeto de conhecimento como temas de um único método, ou seja, assumir uma dimensão de autointencionalidade do ato de conhecer: no momento em que o sujeito se depara com um objeto de conhecimento se dariam inseparavelmente o conhecimento do objeto, do sujeito e do próprio ato de pensar. Todavia, tal proposta parece incompatível com a experiência humana cotidiana, na medida em que podemos pensar num objeto sem nos darmos contas de nós mesmos e sem reparar no próprio ato de conhecer. Outras vezes ocorre o contrário: pensamos em nós mesmos sem nos darmos conta desse próprio ato que nos leva a pensar em nós mesmos. Além do mais, caso esses conhecimentos do objeto, de nós mesmos e do nosso próprio ato de conhecer se dão todos simultaneamente num único ato de pensar, como é possível que os tomemos como assuntos tão heterogêneos? Donde proviria essa nítida distinção? (SELLÉS, 2013, p. 25-26). 
Ante o exposto, uma vez que o conhecimento humano é dual, com método cognitivo e tema distintos, fica estabelecida a condição do homem como ente situado, isto é, um ser cujo autoconhecimento é limitado e adquirido progressivamente. E justamente dessa finitude, depreende-se que o ser humano não dá a si mesmo a razão do seu existir, sendo seu domínio ontológico sobre si - liberdade, adquirido progressivamente pelo exercício de suas faculdades intelectivas e volitivas, através das relações que estabelece com os objetos, com outros sujeitos e com a Transcendência.

\title{
2.4.2 As relações de objetividade, de intersubjetividade e de transcendência
}

Para Henrique Vaz, o homem não é apenas um ser-em-si, que pode ser descrito pelas categorias de estrutura (corpo próprio, psiquismo e espírito), mas também um ser-para, cujas relações que estabelece com o mundo, com as outras pessoas e com a Transcendência preenchem de conteúdo sua própria estrutura ontológica, sendo que essa tríplice modalidade de relação é homóloga aos três níveis ônticos da realidade, cada qual associado pelo filósofo brasileiro a uma das categorias de estrutura:

\begin{abstract}
Ora, em cada uma dessas esferas [de relação com a realidade] observa-se a primazia de uma das estruturas que integram a totalidade do ser-homem: na relação de objetividade a primazia é dada ao corpo próprio, na relação de intersubjetividade a primazia é dada ao psiquismo, e na relação de transcendência a primazia é dada ao espírito. Mundo, História, Absoluto são os três termos das relações constitutivas da abertura do homem à realidade, o que vem a ser sua situação fundamental. A primazia à qual nos referimos significa que o corpo próprio é a condição primeira de possibilidade da nossa presença à realidade na forma de uma abertura constitutiva ao mundo, o psiquismo é a condição primeira de possibilidade da nossa presença à realidade na forma de uma abertura constitutiva ao outro, o espírito é a condição primeira de possibilidade da nossa presença à realidade na forma de uma abertura constitutiva ao Absoluto. $\mathrm{O}$ homem é, pois, ser-em-relação segundo a totalidade estrutural que o constitui como corpo, psiquismo e espírito (VAZ, 1992, p. 14).
\end{abstract}

Uma primeira ressalva que entendemos importante ser feita é que, embora Henrique Vaz comece pelas relações de objetividade, isso não significa que seja essa a ordem cronológica das relações do homem com a realidade, isto é, os três níveis ônticos da realidade não são acessados pelo homem em etapas distintas, o que poria em risco sua unidade. Trata-se 
apenas de uma construção teórica das categorias que reflete sua ordem de inteligibilidade para nós (VAZ, 1992, p. 51-52).

As relações de objetividade se dão a partir da experiência que o homem faz de seu ser situado no mundo. Apesar de ser bastante variada na história da filosofia, a noção de mundo a qual Henrique Vaz dá mais destaque é aquela trazida pela fenomenologia, que realça seu sentido antropológico e que contém as seguintes características: concretude, contrapondose a uma acepção lógica do termo; abertura, no sentido de englobar o homem e ao mesmo tempo permitir ser objeto de sua ação; fundamento de sentido, onde ocorre o 'mundo da vida' propriamente humana; caráter histórico-cultural, manifestado nas visões de mundo que se diversificam no espaço e no tempo; caminho para a transcendência, na medida em que sua estrutura paradoxal englobante e aberta aponta para uma realidade transmundana, refletida na suprassunção da relação de objetividade na relação de transcendência (VAZ, 1992, p. 21-22).

Segundo opinião do filósofo brasileiro, a metáfora que mais bem descreve a noção de mundo é a do horizonte, no sentido fenomenológico de espaço intencional cujos limites estão em perpétuo movimento (VAZ, 1992, p. 20). E numa acepção mais científica do termo, o mundo é visto como natureza, como campo do fazer e do contemplar, enquanto transformado pela técnica e explicado pelos modelos teóricos científicos (VAZ, 1992, p. 24).

Ambas as acepções (fenomenológica e científica) revelam um caráter não passivo na relação do homem com o mundo, na medida em que imprimimos nele a nossa intencionalidade. Portanto, o mundo é visto como tarefa e destino, como algo que está lançado em face do homem e com o qual este estabelece uma relação não recíproca, na medida em que não responde à interpelação feita pelo sujeito, a não ser através da sua própria linguagem, que exprime a significação que jaz silenciosa na estrutura das coisas (VAZ, 1992, p. 22 e 35).

Como o mundo não responde à linguagem do sujeito, é razoável supor a presença de um interlocutor inteligente que seja capaz de ser o destinatário da linguagem, do contrário o emissor da linguagem falaria apenas consigo mesmo, o que não faz muito sentido, dado o caráter público suposto nas diversas formas de linguagem. Tal caráter não privado da linguagem foi defendido por Wittgenstein nos parágrafos 243 a 315 das Investigações Filosóficas (1975, p. 98 a 113) e pode ser resumido da seguinte forma: uma linguagem supõe regras e estas supõem a possibilidade de correção, o que exige um uso não privativo. Com efeito, o próprio sujeito não pode ser a origem da linguagem e da regra de correção da mesma com base no uso, pois é necessário outro usuário da linguagem para garantir a validade do 
critério de correção. Ou, de forma mais sintética, uma regra privada, restrita ao emissor, carece de sentido.

Essa exigência lógica de um interlocutor faz da relação intersubjetiva um pressuposto para qualquer forma de linguagem, abrindo um caminho filosófico de superação das vertentes solipsistas (VAZ, 1992, p. 58). Aqui podemos perceber como Henrique Vaz se contrapõe à proposta humeana. Com efeito, para Hume (2009, p. 292-293) a ficção da própria identidade se dá a partir da associação de diferentes impressões feita por meio da memória e da imaginação. O que é bem diferente do pensamento de Henrique Vaz, no qual o senso de identidade pessoal não é ficcional e nem surge sozinho, mas apenas através da experiência da relação com outros sujeitos. A partir do mútuo reconhecimento contido na relação intersubjetiva, podemos destacar o caráter de reciprocidade, típico dessa espécie de relação, que manifesta o encontro e a abertura entre os dois sujeitos, ambos infinitos intencionais (VAZ, 1992, p. 67). Quando uma das partes não é reconhecida em sua infinitude intencional, isto é, em seu aspecto de sujeito, dá-se a coisificação do outro, o que impede o caráter recíproco, essencial para que se constitua a relação de intersubjetividade (VAZ, 1992, p. 65).

Por outro lado, o mútuo reconhecimento somente é possível em virtude do movimento dialético de identidade na diferença, através do qual, mesmo reconhecendo o outro em sua alteridade, o sujeito continua conservando sua ipseidade. Isso se dá devido à coexistência de duas características ontológicas no homem: o seu ser-para-si, manifestado nas categorias de estrutura, e o seu ser-para-o-outro, descrito pelas categorias de relação (VAZ, 1992, p. 75).

Dando prosseguimento ao discurso antropológico que caracteriza a automanifestação do sujeito, Henrique Vaz conclui as categorias de relação com a relação de transcendência, que suprassume as relações de objetividade e intersubjetividade.

A relação de transcendência se caracteriza pela relação entre o sujeito, infinito intencional, e o Absoluto, infinito real, numa síntese dialética entre interioridade e exterioridade. O Absoluto se apresenta como aquilo que está além da situação do sujeito no mundo e das formas com que ele se relaciona com outros sujeitos, daí sua exterioridade e transcendência, no próprio sentido etimológico da palavra - de trans, mais além e scando, escalar. Ao mesmo tempo, o Absoluto se apresenta como condição de possibilidade que permite ao sujeito articular o discurso antropológico por meio do qual se automanifesta. Essa radical dependência do sujeito em relação ao Absoluto, do qual recebe o ser por participação, 
encontra seu espaço conceitual na ideia de imanência, que aponta para a noção de interioridade (VAZ, 1992, p. 94-96).

A relação de transcendência não é recíproca, nem não recíproca, pois, se por um lado, o Absoluto está para além do mundo físico e do alcance imediato da inteligência humana, por outro se apresenta como fundamento do ato de ser do homem, suposto em qualquer forma de relação, seja ela não recíproca - relação de objetividade com o mundo, seja ela recíproca - relação de intersubjetividade com outros sujeitos (VAZ, 1992, p. 96). Em outras palavras, não sendo uma relação de reciprocidade nem de não reciprocidade, trata-se de uma relação absoluta, na medida em que o homem não tem experiência do outro polo da relação: o Absoluto está para além de qualquer experiência direta com o mundo e com outros sujeitos.

Uma característica específica da relação absoluta é a radical dependência de um dos polos em relação ao outro, dependência essa inscrita na estrutura ontológica do sujeito dependente, conforme exprimiu Henrique Vaz:

... o Transcendente, sendo imanente ao dinamismo intelectual que permite ao sujeito articular o discurso da sua autoafirmação como sujeito e sendo, do mesmo modo, imanente à relação de intersubjetividade como a mais profunda exigência de sercom-o-outro, não se deixa exprimir na finitude da experiência ou do conceito, mas está presente ao conteúdo objetivo do discurso como uma presença ausente, uma presença que se não manifesta como tal, mas apenas como o sinal de uma exigência absoluta que aponta para a direção mais fundamental do movimento do espírito (VAZ, 1992, p. 98).

Tal dependência torna impossível a negação da transcendência, pois no próprio ato de negá-la, já estaria suposta a sua presença, tal como ocorre com a categoria do espírito, de onde brotam as faculdades do pensamento e da liberdade, cuja negação supõe a sua utilização, conforme já tivemos oportunidade de expor anteriormente. Nas palavras de Henrique Vaz:

Compreende-se assim que a negação do espírito, [...] prolonga-se em negação da transcendência, desde que ela implique a referência a um Transcendente absoluto. [...] Mas a ela, como à negação do espírito, pode aplicar-se o argumento de retorsão (elentikôs). Na verdade, a negação da transcendência pressupõe, no espírito, a afirmação implícita da sua abertura transcendental ao ser; ora, não podendo evidentemente, o espírito finito e situado identificar-se com o ser, a identidade (intencional) na diferença (real) põe necessariamente a exigência do Transcendente como Absoluto do ser (VAZ, 1992, p. 97).

O núcleo do argumento de Henrique Vaz parece destacar a possibilidade de se pensar algo para além da experiência, o que manifestaria a existência de uma capacidade no 
ser do homem que provoca nele uma abertura para esse tipo de realidade, um excesso ontológico. Portanto, no ato de negar a transcendência, já estaria implícito uma forma de afinidade com a própria transcendência. Ou seja, não se pode negar a transcendência sem um prévio conhecimento a seu respeito.

Ora, tendo em vista essa inafastabilidade da relação de transcendência, que se apresenta como condição de possibilidade para que o homem se relacione com o mundo e com outros sujeitos, restaria verificar se o ser do próprio homem seria o horizonte no qual deságua a relação de transcendência, ou se seria necessário que tal horizonte apontasse para um Absoluto real.

Pela citação acima, já sabemos a posição de Henrique Vaz sobre o tema: o homem, dada a finitude da sua situação no mundo (evidenciada quando expusemos que seu conhecimento de si é limitado e adquirido progressivamente), não pode ser ele mesmo o seu próprio horizonte transcendental. Deve, portanto, ser posto pelo Absoluto real, através da relação de criaturalidade. No pensamento de Henrique Vaz, o Absoluto real se identifica com o Deus pessoal da tradição judaico-cristã, na medida em que a relação entre esse Absoluto e o mundo se dá a partir da ideia de criação ex-nihilo, tão própria dessa tradição.

A partir da relação de transcendência com o Absoluto, o homem, apesar de sua finitude, abre-se intencionalmente ao infinito do ser, infinitude essa já manifestada de forma imanente pela insaciabilidade da sua inteligência e da sua liberdade.

A nosso ver, há certa semelhança entre a infinitude intencional do ser humano, proposta por Henrique Vaz, e a negação da permanência do sujeito, em David Hume. Isso porque ambos, além de realçarem a constante possibilidade de aquisição de novas experiências, também destacam certo caráter de indefinibilidade e de singularidade inerentes à noção de pessoa, da qual trataremos à frente com mais detalhes.

Da tensão entre a finitude da sua situação no mundo e a infinitude intencional através da qual se abre ao horizonte ilimitado do ser, o homem se descobre como ser-para-oAbsoluto, possuindo como tarefa primordial construir livremente sua própria existência, o que será melhor compreendido a partir da categoria de realização, da qual passaremos a tratar no próximo capítulo.

Nesse mesmo sentido, sintetiza C. Oliveira:

Para Lima Vaz, ao ser posto pelo Absoluto, o homem se descobre como ser-para-oAbsoluto. Em consequência, ele vive a contínua tensão entre a finitude e a abertura ao infinito. Do seio dessa tensão emerge para ele a tarefa de construir a própria vida. 
A unidade que o homem é, ou seja, a unidade essencial como ser de estrutura e de relação deve tornar-se unidade existencial. Posto pelo absoluto, o homem é colocado diante da tarefa de tornar-se aquilo que ele é, ou seja, de realizar-se na abertura para o Absoluto. A oposição dialética entre as dimensões estruturais e as dimensões relacionais constitutivas do ser humano, ou ainda a oposição dialética entre o ser-emsi e o ser-para devem, então, ser suprassumidas na categoria de realização (OLIVEIRA, C., 2013, p. 185).

\subsection{A unidade no ser humano: a categoria da realização}

A categoria da realização é utilizada por Henrique Vaz para descrever o dinamismo através do qual cada homem constrói, por seu agir livre, a unidade que possui potencialmente, assinalada pelas categorias de estrutura; construção essa limitada por sua finitude e situação no mundo, delineada pelas categorias de relação (VAZ, 1992, p. 141). Em outros termos, a categoria da realização expressa a união dialética entre aquilo que o homem é em si mesmo e aquilo com o qual ele se relaciona. Ou seja, Henrique Vaz utiliza essa nova categoria para entrelaçar as categorias de estrutura com as categorias de relação.

Pode-se vislumbrar aqui certa semelhança com a filosofia de Hume, na medida em que ambas concordam com a negação das ideias inatas desvinculadas da experiência, embora se diferenciem no que se refere à natureza da estrutura que será gradualmente preenchida pela experiência: para Hume, tal estrutura é ficcional e aparente, enquanto para Henrique Vaz ela é potencial, atualizando-se ao longo do tempo a partir das relações de objetividade, de intersubjetividade e de transcendência.

Para Henrique Vaz a síntese entre estrutura e relação, ipseidade e alteridade, através da categoria de realização, constituindo uma autêntica identidade na diferença, dá-se por meio de atos praticados no plano histórico da existência, provindo dessa historicidade o aspecto propriamente dinâmico da categoria da realização. Nas palavras do filósofo brasileiro:

A categoria de realização deve mostrar exatamente os caminhos através dos quais a unidade estrutural do homem se cumpre efetivamente nas formas de relação com que ele se abre às grandes regiões do ser que circunscrevem o lugar ontológico da sua situação e da sua finitude. Sendo uno como ser-em-si (substância ou ousía), o homem deve realizar essa unidade como ser-para-si ou como existente para o qual existir é viver a unificação progressiva do seu ser no exercício dos atos que manifestam a 'vida segundo o espírito' como vida propriamente humana.

$[\ldots]$

Por conseguinte, os atos que traçam o itinerário de uma vida que se realiza são atos que procedem do homem pensado na integralidade da sua estrutura e tendo diante de 
si o horizonte inteiramente aberto das suas relações fundamentais. Cada um desses atos será, portanto, a efetivação existencial da unidade do sujeito - unidade que se mostra, pois, como síntese de estrutura e relação - que nele e por ele se realiza [...]. $\mathrm{O}$ rigor dessa dialética traduz a grandeza e o risco de cada ato com o qual procedemos à unificação do nosso ser, pois são atos nos quais está empenhada toda a nossa complexidade estrutural e relacional (VAZ, 1992, p. 144-145).

É a partir da noção de ato, entendida no sentido de perfeição e plenitude de existência, tal como a conceberam Aristóteles e Tomás de Aquino, que Henrique Vaz liga a Antropologia à Ética, conferindo a essa um alcance ontológico com efeitos imanentes no homem:

\footnotetext{
... a unidade existencial do homem, síntese da sua unidade estrutural e dos seus atos - existentis enim est agere -, edificando-se sobre um fundamento ontológico, tem necessariamente um coroamento ético. [...] O homem é um ser constitutivamente ético e essa eticidade é ou deve ser o primeiro predicado da sua unidade existencialmente em devir - ou do imperativo da sua auto-realização (VAZ, 1992, p. 146).
}

Tal eticidade estrutural se encaixa na concepção vaziana do homem como expressividade, possuindo como raiz última o seu ato de ser, do qual falaremos ao tratar da categoria da pessoa no próximo subcapítulo.

É no movimento intencional do sujeito que expressa a si mesmo, que Henrique Vaz busca uma terceira via entre a compreensão do homem como uma substância permanente e inalterável, própria de um essencialismo estático, e a concepção do homem como um aglomerado dinâmico de percepções destituídas de um sujeito, tal como o propôs Hume. Essa via alternativa está contida na categoria de realização, na medida em que se situa entre a essência do que o homem é e a essência do que ele deve ser. Esse dever-ser é retratado nos diversos arquétipos culturais de realização humana, cuja variedade expressa a limitação característica da nossa condição de seres situados.

A passagem do ser do homem para o seu dever-ser não se completa definitivamente em nenhum momento da sua existência temporal, razão pela qual o homem se sente impelido a ser sempre mais. Essa incessante busca de superação faz do homem, na expressão de Henrique Vaz, uma ipseidade dinâmica, ou, em termos pascalianos, o homem supera infinitamente o homem (VAZ, 1992, p. 163 e 172).

A nosso ver, essa concepção dinâmica da essência, centrada na importância e no alcance de cada ato para a realização da grandeza latente potencialmente em cada ser humano, sofre uma clara influência da concepção aristotélica de natureza, a qual possui um forte matiz 
teleológico, sendo entendida como princípio de operação. Destacar esse paralelo com o pensamento do filósofo grego pode nos ajudar a entender melhor a alternativa que Henrique Vaz busca para defender a existência de uma essência no homem, sem cair em concepções estáticas ou naturalísticas. Com efeito, para Aristóteles, a natureza não se reduz a aparência exterior de um ente, ou em termos mais modernos, a natureza de algo não equivale ao seu aspecto fenomênico, devendo abarcar principalmente seu caráter de fonte ou de origem do movimento (ARREGUI; CHOZA, 1995, p. 448). Ou seja, a natureza de algo é aquilo que tem em si o princípio de seu próprio movimento (ARISTÓTELES, Física, Livro II, 192b). Portanto, em tal concepção, a natureza de algo se revela mais no seu agir e no princípio que o origina, do que naquilo que se manifesta num primeiro momento da percepção.

Pois bem, é a partir dessa acepção teleológica e dinâmica da natureza, que se entende a fundo algumas teses aristotélicas de caráter antropológico, tais como o homem é um ser político ou o homem é um ser falante. Ora, não existe uma língua natural, nem uma organização político-social que seja comum a todos os homens. Existem línguas concretas e organizações políticas determinadas em cada tipo de cultura. O natural, portanto, é a realização da aptidão a falar e a organizar-se politicamente, e não uma determinada forma particular histórica de linguagem ou de organização política. Por outro lado, também não é natural a simples capacidade biológica latente no aparelho vocal, devendo a mesma ser trazida à existência através de uma forma cultural específica (ARREGUI; CHOZA, 1995, p. 448449).

Assim, o natural não se reduz àquilo que é dado biologicamente, tal como o concebem as visões antropológicas de cunho naturalista e mecanicista, devendo incluir também e principalmente aquilo através do qual o homem atua num nível especificamente humano. Nesse enquadramento, o cultural é tão natural quanto o biológico, pois da mesma forma que sem cordas vocais um homem não desenvolve a fala, também se não tiver contato com nenhuma forma de cultura, sequer no âmbito familiar, jamais desenvolverá tal capacidade. Portanto, se pode dizer que sem cultura o homem é um ser biologicamente inviável. Além disso, com o avanço tecnológico, o homem se torna cada vez mais capaz de modificar seu próprio organismo, o que denota certa variabilidade inclusive no âmbito do biológico. Deste modo, se pode afirmar que onde houver natureza humana, sempre haverá a presença do histórico e do cultural, os quais constituem dimensões inerentes ao dinamismo essencial do homem. Pensar de outro modo seria professar o mito do estado puro de natureza. (ARREGUI; CHOZA, 1995, p. 458). 
Pois bem, feito esse paralelo com o sentido teleológico de natureza presente no pensamento aristotélico, entendemos restar um pouco mais clara a posição de Henrique Vaz acerca da síntese entre essência, formada pelas estruturas e relações, e existência, construída historicamente por meio dos atos livres de cada ser humano.

Avançando em direção à unidade final do discurso antropológico no qual o homem diz a si mesmo, Henrique Vaz (1992, p. 190) apontará para a categoria da pessoa como expressão definitiva da síntese entre essência (o ser que é) e existência (o ser que se torna ele mesmo). Analisando, pois, essa categoria final, poderemos abarcar em seus principais traços a Antropologia Filosófica de Henrique Vaz, para então compreender até que ponto sua proposta filosófica apresenta-se como uma alternativa de peso para a fragmentação do homem provocada pela crítica humeana à identidade pessoal.

\subsection{A unidade no ser humano: a categoria da pessoa}

A categoria da pessoa apresenta-se como corolário que unifica todas as demais categorias presentes no movimento dialético do discurso. De forma sintética, poderíamos refazer em traços largos o caminho percorrido por Henrique Vaz até aqui, utilizando as palavras do próprio pensador brasileiro:

\footnotetext{
Assim, o "corpo próprio" é suprassumido (ou negado dialeticamente) no "psiquismo" e ambos suprassumidos no "espírito". A região categorial da "estrutura" é suprassumida na região categorial da "relação". No interior desta, a "relação de objetividade" é suprassumida na "relação de intersubjetividade" e ambas na "relação de transcendência". Enfim, a região categorial da "relação" é suprassumida pela "unidade", primeiramente como "unificação" na categoria de "realização", finalmente como "unidade essencial" na categoria de "pessoa", na qual converge e pela qual é suprassumido todo o movimento do discurso (VAZ, 1992, p. 238).
}

Resumido esse itinerário, vejamos que sentido possui a categoria de pessoa no pensamento de Henrique Vaz e de que forma ele defende que tal categoria é capaz de expressar, numa síntese final, a unidade essencial do homem.

Uma das primeiras ressalvas que Henrique Vaz faz ao se deparar com o conceito de pessoa, é assinalar que não se trata de uma categoria que vem acrescentar um conteúdo novo e específico ao discurso antropológico do sujeito que diz a si mesmo. Isso porque, caso 
essa categoria trouxesse um elemento novo, tal elemento se oporia às categorias anteriores do movimento dialético e, dessa oposição, deveria emergir outro conceito que abarcasse e unificasse o discurso antropológico. Portanto, a categoria da pessoa apresenta-se como um verdadeiro caminho metodológico que unifica os sucessivos momentos do discurso e possui a específica função de dar um ponto final ao mesmo, sem deixar de fora nenhum elemento essencial (VAZ, 1992, p. 216).

O fato de apresentar-se como síntese final do discurso, não significa que tal categoria emerge apenas na última fase do mesmo. A pessoa é também o começo do discurso, tendo em vista que é a experiência do sujeito como unidade dinâmica de opostos que o faz perguntar sobre o seu próprio ser, derivando desse questionamento inicial todo o movimento do discurso antropológico.

Em outras palavras, ao pensar a si mesmo numa relação de conhecimento, o ser humano vislumbra sua irredutibilidade à condição de objeto, tendo em vista que tal relação já supõe o próprio sujeito cognoscente. É essa irredutibilidade do sujeito à condição de objeto de conhecimento, que põe em movimento o discurso, o qual visa exprimir, embora não o consiga de forma definitiva, o que o sujeito é em toda a sua riqueza ontológica.

Desta forma, a pessoa apresenta-se como o início e o fim do discurso antropológico, seu vértice conceitual (VAZ, 1992, p. 200), de acordo com a perspectiva com a qual se analise. Do ponto de vista ontológico, daquilo que o homem é em si mesmo, a pessoa é o princípio de inteligibilidade. Numa perspectiva epistêmica, a pessoa é o desfecho que confere uma inteligibilidade final ao questionamento da antropologia filosófica. Henrique Vaz expressa esse caráter nodal do discurso da antropologia filosófica afirmando que na pessoa se entrelaçam a inteligibilidade em-si e a inteligibilidade para-nós (VAZ, 1992, p. 192).

Estabelecidas as ressalvas acima, por meio das quais pudemos entender que, na concepção de Henrique Vaz, a categoria da pessoa acompanha todo o caminho do movimento dialético, sendo sua origem e seu desfecho, ao mesmo tempo em que não encerra em si um elemento conceitual exclusivo não contido nas demais categorias, passemos a analisar em que sentido tal categoria apresenta-se como síntese unificadora do discurso antropológico.

Conforme vimos quando tratamos da categoria de realização, é por meio de seu agir que o homem constrói a unidade potencial latente na sua essência, agir esse que se dá por meio das relações que o homem estabelece com o mundo, com outros sujeitos e com o Absoluto, as quais vão preenchendo de conteúdo aquelas formas estruturais - corpo próprio, psiquismo e espírito, presentes em cada vida humana. 
A categoria da pessoa surge então como síntese unificadora entre a essência - o que o homem é, e a existência, o que o homem se torna no progressivo movimento da vida. Apesar de unificadas, a essência distingue-se da existência na medida em que a situação de finitude temporal da existência humana impede que a infinitude intencional latente nas faculdades do espírito, isto é, na inteligência e na liberdade, se realize de uma só vez no agir humano. Dessa forma, a distensão temporal não permite que o homem exprima de uma só vez e através de um único ato a totalidade da sua essência.

Cumpre destacar que a mencionada temporalidade também é uma dimensão constitutiva da essência humana, e não somente da existência. Com efeito, Henrique Vaz não concebe a essência humana em moldes ahistóricos e fixistas, mas sempre integrada na particularidade histórica da existência de um sujeito que constrói o seu ser através dos seus atos. Essa integração da universalidade da essência na singularidade da existência é inteligível para nós através da categoria da pessoa (VAZ, 1992, p. 191).

Por conseguinte, não há uma perfeita unidade entre aquilo que o homem é em sua essência e aquilo que ele manifesta em sua existência, razão pela qual essa unidade será sempre em devir, uma autêntica unidade dinâmica que se apresenta como a grande tarefa que compete a cada homem realizar. Nas palavras de Henrique Vaz:

\footnotetext{
... sendo essa identidade [entre ser e manifestação] mediatizada pela diferença dos seus momentos, que traduzem a complexidade real do ser humano e a consequente pluralidade das suas formas de manifestação, ela é uma identidade em devir, o resultado sempre recomeçado de uma existência que se realiza.

Compreender filosoficamente o homem como pessoa significa, pois, tematizar essa identidade mediatizada do sujeito consigo mesmo e mostrá-la como termo e princípio de inteligibilidade do movimento de autoexpressão - que é, igualmente, movimento de autoconstituição - pelo qual o homem assume a tarefa fundamental que o define como homem, qual seja a de ser, sendo expressão de si mesmo (VAZ, 1992, p. 218).
}

Essa concepção vaziana da pessoa como unidade dinâmica de opostos visa descrever a experiência que o sujeito faz da sua própria subjetividade, conjugando sua identidade com o seu devir. Nessa descrição estão contidas e harmonizadas uma série de visões filosóficas originalmente divergentes, unificadas na concepção de Henrique Vaz através da categoria da pessoa, pensada por meio do método dialético.

É essa a opinião de C. OLIVEIRA (2013, p. 195 e 196), que destaca a influência da metafísica de Tomás de Aquino na conjugação da identidade da pessoa com a inteligibilidade da existência, concepção esta recepcionada no paradigma hegeliano da 
automanifestação do espírito no tempo; sendo que tal reflexão não se origina de um jogo conceitual, mas da intencionalidade de uma experiência, nos moldes da fenomenologia de Husserl. A concepção de pessoa em Tomás de Aquino já foi enunciada na introdução deste trabalho. A recepção da dialética de Hegel na Antropologia Filosófica de Henrique Vaz também já foi exposta quando abordamos o método de Henrique Vaz. Portanto, aqui resta-nos assinalar brevemente no que consiste a influência de Husserl.

O conceito de intencionalidade, contribuição da fenomenologia de Husserl, propõe a não eliminável tendência da consciência a se referir a algum objeto. $\mathrm{O}$ ato da consciência será sempre a consciência de algum objeto. Por outro lado, também o sujeito, na experiência da sua própria subjetividade, não consegue abarcar a si mesmo de maneira completa como objeto de reflexão, pois sua posição de sujeito é irredutível à posição de objeto.

Ora, da mesma forma, o sujeito pessoal não consegue encarar o mundo numa forma puramente objetiva, numa total assepsia de si. O mundo será sempre o mundo pessoal, restando nos objetos impressa uma marca do próprio sujeito da relação de conhecimento (VAZ, 1992, p. 199). Também quando pensa e expressa a si mesmo, o sujeito é incapaz de ser enquadrado em moldes conceituais objetivos e finitos, restando sempre algo a mais, uma espécie de excesso ontológico, a ser expresso. Em virtude dessa inerente capacidade de transcender qualquer relação de conhecimento, é que Henrique Vaz caracteriza o sujeito pessoal como infinitude intencional: ao dizer a si mesmo através de categorias mentais delimitadas, o sujeito nunca consegue esgotar seu significado, vez que ele é sempre capaz de ultrapassar as determinações finitas, na medida em que está aberto ao horizonte ilimitado do ser (VAZ, 1992, p. 223).

Pois bem, assinaladas algumas das influências filosóficas subjacentes na concepção vaziana da pessoa como unidade dinâmica de oposições, passemos a expor como a unidade na oposição permite superar a aporia da concepção moderna da pessoa, evitando a crítica empirista que põe em dúvida a identidade pessoal em virtude da pluralidade de manifestações do eu, sem que seja necessário recorrer a uma metafísica da subjetividade, que reduz o eu a unidade da consciência de si (VAZ, 1992, p. 195).

Primeiramente, cumpre destacar que a unidade entre o ser que é - essência, e o ser que se torna ele mesmo - existência, é pensável através da categoria da pessoa, a qual permite conjugar dois polos: a subsistência ou o ser-em-si, e a relação ou o ser-para-o-outro.

Segundo Henrique Vaz, a resposta para a superação da aporia entre a singular unidade do ser pessoal com sua consequente incomunicabilidade, e as múltiplas manifestações 
de si através das relações que estabelece, somente é possível por meio da analogia com o conceito de pessoa surgido das especulações teológicas:

\begin{abstract}
A noção de pessoa é, em si mesma, uma noção analógica, e essa estrutura analógica está presente na definição lapidar com que Tomás de Aquino resumiu Boécio: subsistens in rationali natura. A subsistência (o ens in se) exprime a incomunicabilidade radical com que a pessoa é em si mesma unidade absoluta, não partilhada com outro ser (indivisum in se). A natureza racional exprime a universalidade radical (ens ad aliud) com que a pessoa, na sua natureza espiritual, está aberta ao acolhimento de todo ser: nata est convenire cum omni ente. Ora, na sua finitude, que a torna realmente distinta dos outros seres, a pessoa humana não pode realizar em si essa "unidade da unidade e da alteridade" senão verificando analogicamente (pela distinção real na identidade intencional com a universalidade do ser), a identidade absoluta do ser-em-si e do ser-para-outro que só pode ser atribuída ao Absoluto. A aporia [...] resulta da oposição entre o categorial e o transcendental, entre o finito e o infinito presente no próprio coração do eidos da pessoa, uma vez que nela deve dar-se a adequação entre o sujeito e o ser, alvo de todo o movimento dialético no discurso antropológico, sendo o ser, por definição, absolutamente universal (VAZ, 1992, p. 225).
\end{abstract}

O ponto fundamental para compreendermos a citação acima é a definição de pessoa como subsistência de natureza racional. No que se refere à natureza racional, dela já discorremos ao longo da categoria do espírito, apontando sua imaterialidade quando assinalamos sua reflexividade, sua capacidade de percepção do entorno não condicionada à situação orgânica do sujeito, bem como o caráter simultâneo e não cronometrável de sua atividade. Quanto à analogia com o Absoluto, dela já falamos ao tratar da experiência do espírito como synesis e quando destacamos, seguindo Henrique Vaz, que a categoria do espírito é o ponto de encontro entre metafísica e antropologia filosófica. Resta-nos, pois, esclarecer melhor o que significa especificamente a propriedade da subsistência.

Subsistência significa ter o ser como próprio, ser individualmente por si mesmo, ser uma unidade e uma totalidade distinta de qualquer outra realidade. Somente o indivíduo existe realmente, pois o ato de ser não é recebido por uma essência universal, afinal as ideias somente possuem uma existência lógica e não ontológica. No entanto, deve-se frisar que o fato de ser individual não implica necessariamente na subsistência. As qualidades acidentais participam da individualidade da substância, embora não existam por si mesmas.

Da subsistência decorre o atributo da incomunicabilidade: o sujeito subsistente não pode ser participado por outro (ALVIRA, 2014, p. 147). Assim, embora o sujeito subsistente possa compartilhar sua natureza ou mesmo alguma qualidade que possui, contudo não pode transmitir aquilo que ele é em si mesmo, seu caráter de sujeito distinto.O caráter de distinção dentro de uma natureza, próprio do conceito de pessoa, pode ser pensado a partir da 
nossa experiência, pois não se trata de um mero jogo linguístico ou de um sistema conceitual, mas de uma realidade ontológica com plena eficácia na vida cotidiana.

Nesse sentido, Ricardo Stork (1997, p. 12-15) descreve a pessoa, conforme já mencionamos quando tratamos da experiência do espírito enquanto pnêuma, como portadora de intimidade, um mundo interior ao qual somente a própria pessoa tem acesso e àqueles a quem ela permite revelar. Esse mundo interior não tem paralelo: é único e irrepetível, pois cada experiência é sempre um fenômeno particular e novo. Manifestação dessa unicidade da pessoa humana é o rosto e, sobretudo, o olhar, verdadeira expressão corporal da interioridade pessoal. E, da mesma forma que o olhar, também as experiências pessoais são sempre irrepetíveis. Assim, para citar um exemplo ilustrativo, mesmo que muitas pessoas tenham se apaixonado na história humana, a relação amorosa particular entre duas pessoas é sempre algo inédito.

Segundo o mesmo autor, a intimidade pessoal também pode ser entendida como uma espécie de 'dentro vivo', como uma fonte, da qual emergem ocorrências que preenchem o mundo de novidades. Esse dentro vivo é uma realidade imaterial, pois indestrutível. Tudo o que é material, pode ser decomposto. No entanto, temos a experiência de que há em cada ser humano um núcleo interior indestrutível, imutável pela ação de causas que não sejam a própria pessoa. É o caso das convicções, que só podem ser mudadas a 'partir de dentro', sendo a força física impotente para aniquilá-las, tal como se pode visualizar em tantos casos de sequestro em que a vítima não perde sua dignidade de agente livre, ou mesmo dos mártires que abrem mão da própria vida para defender a inviolabilidade desse núcleo íntimo de convicções.

É interessante notar, que, no mesmo sentido que Stork, também Henrique Vaz entende a experiência do ser pessoal como vivência da própria interioridade, a qual, se por um lado, é radicalmente inalienável, por outro, anseia por abrir-se aos outros, nas mais variadas formas de relação, numa verdadeira síntese de interioridade e exterioridade (VAZ, 1992, p. 207). Esse movimento de abertura, unido a uma forma intensa de interioridade, permite que a relação de um ser pessoal com a realidade seja muito mais profunda e interior, além de ser a única via para que o ser pessoal esteja presente a si mesmo, conforme destaca Henrique Vaz:

Na sua plenitude como compenetração de presenças (sendo essa a definição de toda experiência), a experiência do existir pessoal se caracteriza pela intensidade e a nitidez da presença da realidade que nos é exterior no espaço interior da nossa presença a nós mesmos, já que não nos é dada a intuição direta da nossa própria essência. Assim, nossa presença ao outro (categorias de relação) não resulta do fato 
de ele estar simplesmente diante de nós numa relação especular, mas da sua presença no interior da nossa própria presença a nós mesmos que assim se mostra, pela sua própria natureza, presença aberta ao horizonte infinito do ser. Tal é a estrutura fundamental da experiência da pessoa (VAZ, 1992, p. 208).

O contato íntimo da alteridade no âmago da própria ipseidade se realiza na operação de conhecimento, a qual somente é possível em virtude da dimensão espiritual inerente aos seres pessoais, que provoca neles uma intrínseca abertura para o horizonte ilimitado da transcendência do ser. Esse encontro dos objetos na ipseidade do sujeito dá-se no ato do conhecimento, que consiste na posse intencional de uma forma. Passemos a analisar o significado dessa posse intencional, a fim de compreendermos melhor como se conjuga a unidade ontológica da pessoa com sua radical abertura à alteridade.

Posse intencional se contrapõe à posse material. Caso o ato do conhecimento consistisse numa posse material, deveriam ser produzidos efeitos materiais no sujeito cognoscente, o que não ocorre, consoante nos atesta a experiência. Nesse sentido, sabemos que o fogo pensado não queima, bem como o mero conceito de frio é incapaz de gerar uma redução na temperatura corporal. Portanto, conhecer uma ideia ou uma sensação diz respeito, em última instância, a um acontecimento que ocorre numa dimensão imaterial do sujeito cognoscente.

Assinalar essa dimensão imaterial do conhecimento, não significa, de forma alguma, negar sua dependência da experiência sensível, canal pelo qual nos chegam as formas. Justamente por isso se pode diferenciar, por exemplo, a realidade do frio de sua correspondente sensação e conhecimento. Com efeito, o frio no objeto real pode ser medido pela diminuição da energia cinética, enquanto na sensação não pode ser medido, embora possa ser localizado espaçotemporalmente, na medida em que é este frio que estou sentido, e não outro. Já na ordem do intelecto, o frio não é medido nem sentido, mas apenas conhecido. A aferição dessa cognição intelectual do conceito pode ser feita através da análise do seu uso na linguagem (ARREGUI; CHOZA, 1995, p. 146-147).

Dizer que o ato do conhecimento consiste numa posse, significa que a forma conhecida pelo intelecto é a mesma que informa o objeto real. Ou seja, não se trata de uma reprodução ou cópia imanente, construída pela imaginação ou pela memória, que possuiria um correspondente mais ou menos fidedigno na realidade extramental. Trata-se, antes, da mesma forma, existente primeiramente no objeto e posteriormente, com uma existência intencional, no sujeito do conhecimento. Em outras palavras, a forma que atualiza determinada porção de 
matéria do objeto conhecido é a mesma que determina o intelecto do sujeito cognoscente (ARREGUI; CHOZA, 1995, p. 149).

Afirmar que o conhecimento é uma posse denota seu caráter de ação. E isso é importante para diferenciarmos essa concepção das filosofias inatistas ou empiristas. Ambas transferem a intencionalidade do conhecimento para as ideias, sensações ou representações e não para o ato de conhecer. Conforme mencionamos acima, a intencionalidade consiste na inerente referência de qualquer ato cognitivo a um objeto distinto de si. Quem pensa, vê ou sente sempre pensa em algo, vê algo ou sente algo (ARREGUI; CHOZA, 1995, p. 147). Nunca há uma identidade absoluta entre a ação de pensar e o conteúdo dessa ação. Mesmo quando refletimos sobre nossa própria ação de pensar, captamos nosso pensamento como objeto, e não como ato, na forma do que já expusemos quando destacamos que o pensamento acerca do pensamento não é capaz de realizar o ato de pensar.

Se a intencionalidade fosse transferida do ato de conhecer para a ideia ou imagem ou representação mental do objeto, o problema da intencionalidade restaria insolúvel (ARREGUI; CHOZA, 1995, p. 149). Afinal, como garantir que a imagem mental que representa o objeto seja referente especificamente àquele objeto? Parece-nos que não foi outra a conclusão cética do empirismo de Hume, o qual, segundo já expusemos, não oferecia garantias extramentais para nossas ideias e impressões.

Por se tratar de uma posse intencional, o ato do conhecimento é um acontecimento imaterial e, portanto, possui um caráter não processual, evidenciado por sua instantaneidade e pela simultaneidade entre a ação e o resultado, tal como expusemos no tópico referente à teoria hilemórfica. Justamente por isso, o ato de pensar já é o pensado, bem como o ato de ver já é o visto, não havendo uma etapa intermediária entre os atos de natureza cognitiva e seus efeitos. Ressalte-se, porém, que essa identidade diz respeito ao ato de pensar ou de ver, e não propriamente ao sujeito cognoscente e ao objeto conhecido. Entre ambos os entes se mantém a distinção ontológica, limitando-se a identidade ao ato do conhecimento.

Também não se pode confundir o processo de recepção de um estímulo físico com o ato do conhecimento, seja um conhecimento sensível, seja um conhecimento conceitual. Tal processo de recepção do estímulo se dá por etapas e no âmbito material. Assim, a recepção física do estímulo e a consequente alteração do órgão sensorial correspondente não estão contidas na apreensão da forma, tanto a sensível como a inteligível, embora constituam uma etapa pré-cognitiva (ARREGUI; CHOZA, 1995, p. 153-154). Esse não comparecimento do estímulo sensível ao ato de formalização intencional manifesta-se no fato de que na ação de 
conhecer não temos consciência dos mecanismos fisiológicos cerebrais necessários para realização dessa ação, ou seja, ao pensar em algo, não necessitamos pensar simultaneamente nas etapas fisiológicas que nos permitem ter aquele pensamento. Também no ato da visão ação de natureza cognitiva - não enxergamos nosso nervo óptico, nem a captação do estímulo luminoso e sua consequente transmissão ao cérebro. Vemos apenas o objeto que está na nossa presença.

Como consequência do ato do conhecimento, surge o conceito, que não é mais do que a própria forma apreendida. Esta forma sempre é acompanhada de um veículo sensorial, alguma imagem mental particular, sem a qual o conceito apreendido não é atualizável e, portanto, pensável. Tal imagem associada é variável, podendo consistir numa imagem visual, numa figura mais ou menos definível, ou mesmo na imagem auditiva da palavra correspondente. Embora, sempre se dê a associação entre o conceito e alguma imagem mental, deve-se ressaltar sua distinção. O conceito é sempre universal e pode determinar o correto uso de uma palavra, seu sentido, enquanto a imagem não. Assim, se tenho o conceito de cor, que é uma específica aptidão mental, sou capaz de construir com destreza e habilidade uma série de proposições sobre cor, enquanto a mera imaginação de algumas cores não me dê essa capacidade mental (ARREGUI; CHOZA, 1995, p. 296; 298-299).

Assim, estabelecidas essas considerações a respeito da natureza do ato do conhecimento como posse intencional e, portanto, imaterial, das formas do real, podemos compreender melhor de que modo se conjugam na pessoa a unidade dinâmica entre o em-si do sujeito e sua abertura à totalidade do ser. A nosso ver, tal concepção apresenta-se como uma alternativa válida para as visões modernas acerca da natureza do sujeito, tendentes a se polarizarem, conforme destacou Henrique Vaz (1992, p. 195), ora em torno da unidade da consciência de si, ora em torno da pluralidade das manifestações do eu.

Enfim, até aqui, tratamos da categoria da pessoa como síntese unificadora de essência e existência, início e fim do discurso antropológico através do qual o homem exprime a si mesmo. Tal categoria permite compreendermos o homem como uma unidade dinâmica que conjuga subsistência ontológica com a capacidade de abertura ao real, por meio da posse intencional das formas dos entes, realizada graças à racionalidade de sua natureza.

Ora, para concluir essa breve exposição acerca do conceito de pessoa na Antropologia Filosófica de Henrique Vaz, passemos a analisar um último aspecto: a centralidade do ato de ser na constituição metafísica da pessoa. Apesar de termos deixado para 
o final, esse último aspecto não é o menos importante, muito pelo contrário: trata-se do epicentro que subjaz na concepção antropológica do filósofo brasileiro.

Nesse sentido, Henrique Vaz (1992, p. 216-217) admite que adotou a concepção do homem como expressividade como base teórica da sua Antropologia Filosófica. Ora, por expressividade o filósofo brasileiro entende que, no caso do homem, a sua forma, isto é, aquilo que o organiza internamente e o distingue dos demais seres, é recriada na livre expressão do seu próprio ser. Isso significa que o homem possui uma forma naturalmente dada, mas não determinada pela necessidade da natureza, como é o caso dos seres não pessoais. Essa forma inicialmente dada pode e deve ser trabalhada pela liberdade do sujeito que a media, cabendo ao homem ser artista de si, ao expressar livremente a sua própria forma.

Pois bem, esse domínio sobre o seu próprio ser, ao qual chamamos liberdade, revela a singularidade ontológica do homem frente aos demais seres da natureza. Tal domínio provém, em última instância, da peculiar intensidade que o ato de ser possui nos seres pessoais. Vejamos, portanto, o que significa propriamente o caráter intensivo do ato de ser, bem como sua relação com a essência na constituição ontológica do homem.

No aristotelismo o ser possui uma pluralidade de significados, seja na realidade, seja na predicação, podendo tais significados ser agrupados em quatro grupos mais gerais, a saber: o ser como substância e como acidente, isto é, o ser subsistente e o ser coincidencial; o ser verdadeiro e o ser falso; o ser categorial e, por fim, o ser como ato e como potência.

Tomás de Aquino introduz uma novidade perfeitamente compatível com esse quadro aristotélico do ser, que o unifica e o combina com a teoria platônica da participação e com a noção de criação advinda da revelação judaico-cristã (OLIVEIRA, C. 2013, p. 118 e MELENDO, 2002, p. 133). Tal novidade consiste na introdução da noção de ato como elemento primigênio e fundamental da ousía aristotélica. A esse elemento novo, que Tomás de Aquino entendia presente no pensamento de Aristóteles, mas que na opinião de muitos, trata-se da algo original e inclusive a principal contribuição do Aquinate à história do pensamento filosófico, chamou pelos nomes esse e actus essendi.

Por se tratar de uma noção fundamental, não é fácil definir o que significa ato. Por essa razão, Aristóteles (Metafísica, Livro $\Theta, 1048^{a}$ apud REALE, 2005, p. 409-411) recorre ao método indutivo, partindo de uma série de exemplos para assinalar a realidade do ato, a qual se torna mais clara à inteligência quando contraposta à noção de potência. Ato seria propriamente o exercício de determinada perfeição, enquanto potência seria a capacidade de exercitar a perfeição dada pelo ato. Assim, para ilustrar com um exemplo, a visão é um ato, 
enquanto a capacidade de ver, uma potência. A potência já possui em si algo de ato, uma vez que a capacidade de ver já é uma perfeição. Ou seja, potência não significa ausência de ato. Com efeito, não é o mesmo ser cego e estar de olhos fechados. Portanto, podemos dizer que potência e ato são dois princípios entitativos da realidade, na qual o ato possui prioridade de perfeição, de conhecimento e de causalidade. Isso porque a potência está ordenada para o ato como seu fim, na medida em que encontra nele sua razão de ser. Afinal, a capacidade de ver existe para a realização do ato da visão.

$\mathrm{O}$ ato de ser designa o maior dos atos, aquela perfeição originária de qualquer entidade, na qual encontram o fundamento último todas as propriedades do ente. Podemos dizer que o ato de ser é universal, total e radical. Universal porque presente em tudo o que existe, na medida em que tudo o que existe é. Total, pois engloba todas as perfeições dos entes, em suas diferentes modalidades de ser. Radical porque é aquilo que faz com que as coisas sejam, isto é, o que há de originário e mais fundamental em cada perfeição, pois cada perfeição supõe o ser. Desta feita, não se há de pensar que as demais perfeições são alheias ao ato de ser, mas sim que este ato abarca cada uma das perfeições.

A potência que se relaciona diretamente com o ato de ser é a essência. A composição dual de essência e ato de ser é própria dos entes finitos, visto que nenhum deles esgota a perfeição do ser. Nessa relação, a essência, que podemos definir como aquilo pelo qual alguma coisa é, exerce a função de contração do próprio ato que a instaura na realidade, conferindo ao ato de ser uma limitação a um modo específico.

Essa posse limitada de uma perfeição traz à tona o caráter intensivo do ato ser, ou seja, o mesmo pode ser contraído em diferentes graus, de acordo com a essência na qual é recebido. A recepção não significa uma preexistência da essência em relação ao seu ato, pelo contrário, é o ato quem faz ser a potência, a qual, por sua vez, contrairá o próprio ato que a instaura.

Ora, possuir uma perfeição de modo limitado, ou seja, apenas em parte, implica uma participação, a qual exige por si só uma dualidade de princípios: o participante -, sujeito que recebe a perfeição e a limita -, e o ato da perfeição participada. Havendo, portanto, uma primazia do ato de ser em relação à essência, e considerando que o ato de ser dos entes remete ao Ato Puro de Ser do qual participam, vemos um traço importante da teoria da participação de Platão, casada com ontologia da potência e ato de Aristóteles, unificadas a partir da noção de ser como ato intensivo, proposta por Tomás de Aquino. 
Isso de dá da seguinte forma: no Absoluto do Ser, o seu Ato encontra-se num estado Puro, na medida em que não é contraído por nenhuma essência. A noção de Deus como Ipsum Esse Subsistens, Aquele que possui o ato de ser por si mesmo, Tomás de Aquino a retirou da famosa passagem bíblica do livro do Êxodo $(3,14)$ quando Deus responde a Moisés: "Eu Sou Aquele que Sou”. Na opinião de Gilson, longe de significar uma pura abstração desprovida de qualquer conteúdo determinado, "a noção do puro esse indica um ser realmente subsistente, cuja perfeição não tem limites. Deus é absolutamente distinto de todos os outros entes, cada um dos quais tem uma essência distinta de sua existência. E isso porque é Ele mesmo o seu próprio ato de ser. A pureza existencial de Deus o individualiza, por assim dizer, e o coloca à parte de tudo o mais." (GILSON, 1962, p. 34).

A relação entre o Ato Puro, perfeição participada, e os demais atos de ser, perfeições participantes, ocorre também nos moldes da relação entre ato e potência. Dessa forma, o ato de ser dos seres finitos está em potência em relação ao Ato Puro, na medida em que deste dependem diretamente, não somente quanto à origem, mas também no que se refere à sua conservação. Com efeito, assim como o ato possui a primazia ontológica e causal frente à potência que atualiza, na medida em que esta somente passa à condição de ato ao receber deste o influxo da perfeição comunicada, tal como, a guisa de exemplo, a possibilidade do aumento da temperatura necessita da ação do calor para se realizar, assim também o ato de ser dos seres finitos não possui origem em si mesmo, dependendo, para sua origem e subsistência, da potência ativa do Ato Puro.

Pois bem, o ato de ser apresenta-se como uma espécie de coluna vertebral que integra todos os elementos entitativos das criaturas, além de remeter a uma participação transcendental no Absoluto do Ser, numa espécie de efeito cascata, conforme bem sintetizado por Alvira:

Segundo recorda Tomás de Aquino, a ação divina criadora tem como efeito imediato o ato de ser das criaturas, que participa da criação da essência que o recebe: assim, cada esse se configura como a primeiríssima e fundamental participação do Ser divino. Por sua parte, ao mesmo tempo em que o contrai, a essência participa do ato de ser que a constitui; e se é composta, nessa essência por sua vez a matéria participa da forma e, através dela, do próprio ato de ser. Por sua parte, os acidentes -e, sobretudo, a operação -, representam sucessivas e hierarquizadas participações do actus essendi, mediadas pela substância: considerados em si mesmos, devem ser percebidos como encarnações ontologicamente mais débeis que a substância em que inerem; mas enquanto expansão terminal do próprio ser - e como complemento da substância que os sustenta -, encerram de algum modo o ciclo pelo qual o esse progressivamente atualiza seu sujeito, incrementando sua participação nas perfeições do Absoluto... (ALVIRA; CLAVELL; MELENDO; 2014, p. 341-342). 
A distinção entre o ato de ser e a essência, bem como a primazia do primeiro, se manifesta na linguagem, particularmente através do juízo, a segunda operação do intelecto, conforme a terminologia escolástica. Através da ação judicante, o intelecto, mediante a cópula verbal, compõe e divide os conceitos apreendidos por abstração na primeira operação do entendimento. $\mathrm{O}$ verbo ser significa não somente a predicação, mas primeiramente a própria efetividade ontológica a que se refere o conceito, o qual expressa a essência de algo. $\mathrm{O}$ conceito somente existe, é inteligível e exprimível, por conter em si mesmo o esse (OLIVEIRA, J. 2013. p. 20).

Além de tornar o conceito inteligível e exprimível, o esse abre a inteligência humana para o horizonte infinito da transcendência, na medida em que aponta para além dos limites do objeto particular de conhecimento, na forma do que expôs Celestino Pires ao tratar da unidade analógica subjacente a cada afirmação:

... o conhecimento humano projeta-se sempre para além dos objetos particulares
dados e a todos sintetiza na unidade da afirmação. Todas as coisas são. A
inteligência humana está assim aberta a um horizonte infinito que põe,
dinamicamente, em cada ato de afirmação. Ela não pode aquietar-se na afirmação do
particular, porque no ato mesmo em que conhece o objeto finito, e o reconhece como
finito, transpõe os limites do dado singular afirmado. [...] Este movimento real da
inteligência para o ser sem limites, que não é 'isto' ou 'aquilo', mas simplesmente
'é', implica um termo também real que, portanto, é implicitamente posto em
qualquer afirmação. A posição do absoluto é, pois, uma condição de possibilidade de
toda e qualquer afirmação de objetos particulares. Sendo assim, qualquer afirmação
de um objeto finito implica uma referência, essencial e constitutiva, ao Infinito
(PIRES, 1989, p. 249).

Também Henrique Vaz defende que é no dinamismo intrínseco da afirmação que se transgride a limitação eidética - apreensão do conceito - para se chegar à universalidade do ser - ilimitação tética - a verdadeira finalidade do processo cognitivo, o qual aponta diretamente para o real - extramental - permitindo à inteligência escapar ao domínio da mera representação lógica ou linguística (OLIVEIRA, J. 2013. p. 20).

Essa superação da ordem lógico-formal em direção ao real somente é possível através da concepção do ser como atualidade que transcende todo o conteúdo formal. E, nessa mesma linha de pensamento, Gonzales propõe a noção de supraformalidade para designar a natureza do ato de ser com sua consequente superação da ordem predicamental, repercutindo diretamente na noção de pessoa:

... a substância ou a forma, por assim dizer, não é rebaixada em sua categoria, não fica diminuída ; ao contrário, sua altura e dignidade são realçadas quando integradas 
ao ser, que -- como dizia Tomás de Aquino - é a forma das formas. O ser confere uma unidade mais alta, e ele é - se pode ser expresso assim - maximamente integrador. O ser considerado de uma maneira supraformal, une ou integra as formas, as diferenças formais. E, por esta razão, no meu modo de ver, a visão estática e dinâmica da pessoa são só dois aspectos da mesma realidade. (GONZALES, 2008, p. 56).

Diante do que expusemos até aqui a respeito da natureza do ser como ato intensivo, passemos a analisar os reflexos dessa noção no conceito de pessoa.

Conforme mencionamos, há nos seres pessoais um domínio ontológico, que lhes permite possuir de maneira mais intensa o seu próprio ser, a tal ponto que se pode dizer que o possuem como "propriedade privada" segundo terminologia de Melendo (2002, p. 170), o que se manifesta pelo exercício da liberdade. Podemos dizer, portanto, que os seres pessoais possuem um ato de ser num outro grau ontológico, acima dos seres infrapessoais, o que levou Tomás de Aquino a afirmar que "a pessoa é o que há de mais perfeito em toda a natureza" (S. Th. I, q. 29, a. 3).

Esse transbordamento ontológico proveniente do ato de ser pessoal permite que a forma, que na composição do ente atua como sujeito que recebe o ato de ser, não tenha na matéria uma contraparte necessária para sua subsistência enquanto tal, o que confere a estes indivíduos um caráter de espiritualidade, conforme argumenta Tomás de Aquino:

Nas coisas que se relacionam entre si, sendo uma a causa do ser da outra, aquela que exerce a função de causa pode ter ser sem a outra, mas o contrário não vale. Ora, essa é a relação existente entre a matéria e a forma, pois a forma dá o ser à matéria. Por isso, é impossível à matéria ser sem alguma forma. Porém, não é impossível haver alguma forma sem matéria. A forma, com efeito, como forma, não é dependente da matéria. Todavia, se existem algumas formas que não podem ser senão na matéria, isso é devido a estarem distanciado do primeiro princípio, que é o ato primeiro e puro. Consequentemente, aquelas formas que mais se aproximam do primeiro princípio são formas que subsistem por si mesmas, sem matéria. A forma, como foi dito acima, não necessita da matéria segundo todo o seu gênero. Tais formas são as inteligências. Donde não ser necessário que as essências ou qüididades dessas substâncias sejam outra coisa que a sua própria forma (TOMÁS DE AQUINO. 1981. p. 79).

Além da liberdade, a dimensão imaterial dos seres pessoais se manifesta nos seus atos cognitivos, como a visão e o pensamento, segundo já expusemos anteriormente. E, a partir da constatação desse caráter imaterial, resta assinalado o caminho teórico para a fundamentação da hipótese da incorruptibilidade e da imortalidade da alma humana, assunto muito interessante, mas sobre o qual não nos deteremos, por ultrapassar os limites do presente trabalho. 
A espiritualidade da forma humana faz de cada homem um sujeito absoluto, no sentido etimológico da palavra: ab solto, não completamente ligado à mutabilidade e a corruptibilidade próprias da matéria. A imaterialidade desse núcleo mais íntimo da forma humana põe de manifesto a eminente dignidade da pessoa, especialmente quando comparada com outros seres do mundo material, marcados pela corruptibilidade, na forma do que expõe de maneira poética C.S. Lewis:

Não há gente vulgar. Nunca falamos com um mero mortal. Mortais são as nações, culturas, correntes artísticas e civilizações. Sua vida é tão comparável à nossa quanto a de um mosquito. Os seres com quem brincamos, trabalhamos, nos casamos, aos quais humilhamos e exploramos são imortais: horrores imortais ou esplendores inacabados (LEWIS apud MELENDO, 2002, 173).

Nessa mesma linha, mas com uma linguagem mais filosófica, também expõe Cafarra:

\begin{abstract}
... a nobreza, a dignidade ontológica da pessoa, é infinitamente superior à de todos os outros entes criados: situa-se em um grau de ser cuja distância, em relação aos graus de ser dos outros entes, é infinitamente infinita, para usar a terminologia pascaliana. Enquanto que o indivíduo não pessoal, devido à sua diversa constituição ontológica, é um 'momento' de uma linha, uma parte de um todo, um evento passageiro da disposição da matéria, a pessoa é em si, e não é parte de um todo: é um sujeito eterno (CAFARRA, apud MELENDO, 2002, 177).
\end{abstract}

Ressalte-se, porém, que, em virtude da unidade da pessoa humana, enraizada no seu exímio ato de ser, a dignidade da alma reverbera no corpo, nos moldes do que expusemos ao tratar da teoria hilemórfica e da consequente consideração da alma como forma do corpo. Nesse sentido, esclarece Tomás de Aquino:

E devido a esse motivo de ter a alma humana, entre as demais substâncias inteligíveis, mais de potência, torna-se ela tão próxima das coisas materiais que estas são levadas a participar do seu ser, de modo a resultar da alma e do corpo um ser e um composto, embora este ser, enquanto é da alma, não seja dependente do corpo. (TOMÁS DE AQUINO, 1981, p. 83).

Essa unidade e dignidade estão impressas na própria estrutura do corpo humano, dotado de funções intelectivas, na forma do que mencionamos ao analisar a categoria do corpo próprio em Henrique Vaz.

Por derivar de seu ato de ser, a dignidade da pessoa humana é uma realidade dada, que não depende dos seus atos, nem das suas relações, os quais pertencem à ordem dos 
acidentes. Como o ato de ser é um só, e dele participa todo o composto, as operações da pessoa (seja o conhecimento de si, o livre-arbítrio, a capacidade de responder pelos seus atos, ou mesmo sua capacidade de estabelecer relações com outros indivíduos) embora manifestem a grandeza do ato de ser pessoal, todavia não são sua causa, nem sua condição de possibilidade (ALVIRA; CLAVELL; MELENDO, 2014, p. 153). Por essa razão, a pessoa é digna por si mesma, independente de suas capacidades e realizações, ou mesmo de seu reconhecimento social. Outro desdobramento do caráter intensivo do ato de ser na noção de pessoa reside na compreensão do aperfeiçoamento essencial a partir do dinamismo do esse. Vejamos brevemente o que significa isso.

Segundo Norris Clarke (1998, p. 6), a noção de ser como ativo e expansivo está presente na ontologia de Tomás de Aquino, embora essa questão não tenha sido especificamente formalizada pelo Aquinate. Clarke (1998, p. 8) defende que todo ente, ao possuir um ato de ser, tende a expressar-se e a comunicar-se, de tal forma que sua plenitude ontológica, seu supremo télos, consista na comunicação de si. Em outras palavras, há um imenso dinamismo inato no ato de ser, que se esforça por levar cada ente do interior de sua mais profunda realidade até sua completa autorrealização, a qual se efetiva quando o ente se comunica por meio de sua ação, compartilhando à sua volta suas próprias riquezas ontológicas.

A origem dessa tendência inata à autocomunicação reside nas facetas transcendentais de unidade e de bondade do ser. Nesse sentido, Clarke entende que Tomás de Aquino juntou a intuição filosófica da difusibilidade do bem proposta pelos platônicos com a revelação cristã do amor trinitário como verdadeira natureza do Ser Absoluto:

O que a doutrina sobre a Trindade ensina é que a verdadeira natureza íntima do Ser Supremo- mesmo antes do seu transbordamento para a criação - consiste num processo extático (para além do tempo e do movimento) de amor autocomunicativo: o Pai, o não gerado processor da infinita plenitude da natureza divina, comunica extaticamente sua inteira natureza divina para a Segunda Pessoa, o Filho ou a Palavra, num amoroso ato de autoconhecimento, a tal ponto que a única distinção entre eles é a distinção de duas relações opostamente complementares, Doador e Recebedor. Então ambos unidos, num único ato de amor mútuo, põem adiante a mesma divina essência em toda a sua plenitude para a imagem amorosa delas, o Espírito Santo, a terceira Pessoa. Portanto, a vida íntima do próprio Deus, a suprema plenitude de tudo o que significa ser, é em sua própria natureza, Amor autocomunicativo, o qual, consequentemente, transborda livremente na autocomunicação finita que é a criação. Não é por acaso, portanto, que a autocomunicação está verdadeiramente inscrita no coração de todos os entes, como imagem verdadeira, embora finita, da sua Fonte. Filosofia e revelação caminham aqui de mãos dadas para descortinarem as profundas dimensões do significado do ser. (CLARKE, 1998, p. 11-12, tradução nossa). 
Ora, a compreensão do esse como intrinsecamente ativo e expansivo, orientado para a automanifestação e autocomunicação, permite-nos compreender com maior nitidez os principais traços metafísicos dos entes pessoais. Com efeito, conforme mencionamos anteriormente, os seres pessoais carregam em si mesmos um esse mais intensivo, visto ser menor a modulação efetivada por sua essência, o que leva essa classe de entes a serem mais ativos, possuindo a si mesmos, na forma do que manifestam suas operações racionais e livres. Justamente por isso se pode afirmar que o ser por excelência, aquilo que há de mais perfeito e digno em toda a natureza, é a pessoa.

Em decorrência desse caráter dinâmico e expansivo inerente ao ato de ser, que nos seres pessoais atinge maiores proporções, Clarke propõe uma compreensão diádica (1998, p. 15-16) da pessoa, constituída por dois polos: o polo substancial e o polo relacional. O primeiro se manifesta na autoconsciência (inteligência) e na autodeterminação (vontade), enquanto o segundo se revela na autocomunicação, isto é, na capacidade de se abrir, através da recepção e da doação de si. Assim, substancialidade (ser-em-si) e relacionalidade (ser-para) alimentam-se mutuamente, na medida em que o domínio de si permite a doação aos demais e, nesse movimento de doação, a pessoa se enriquece ontologicamente. Portanto, partindo da concepção intensiva do esse, podemos afirmar que a substância e a relação são aspectos primordiais da realidade da pessoa.

É interessante destacar como o duplo movimento do domínio de si e da doação aos demais, permitido pela intensidade do esse pessoal, possibilita-nos compreender melhor o modo como se dá o aperfeiçoamento essencial que emana do ato de ser. Com efeito, a partir da distinção real entre ato de ser e essência, distinção que não é separação, podemos situar a pessoa mais propriamente no plano do ato, na medida em que é este quem tem a primazia ontológica, na forma do que já vimos. Pois bem, a configuração essencial, que confere ao ato de ser um modo próprio, não o cristaliza, nem o destitui do seu intrínseco dinamismo, de cujo transbordamento se beneficia a própria essência. Tal transbordamento se manifesta no dinamismo da pessoa, cujas operações contribuem para o seu próprio aperfeiçoamento essencial. Do contrário, não havendo uma instância superior que aperfeiçoasse a essência, restaria inexplicável o aperfeiçoamento de cada ser humano. Justamente por isso, se pode identificar a pessoa com seu próprio esse, a quem foi dada a essência, a modo de posse.

Nessa perspectiva, a realidade mais nuclear que constitui a própria pessoa é sua distinção e intimidade, sendo impossível definir-lhe, na medida em que qualquer tipo de definição exigiria situar a pessoa no plano estrutural da essência. Em outras palavras, por 
restar identificada com seu próprio ato de ser e considerando que o ser transcende qualquer forma de categorização, a realidade mais íntima da pessoa é tão indefinível quanto a noção de ato. Dessa indefinível perspectiva da pessoa considerada a partir do âmbito do ato, pode-se concluir que não há uma perfeita identidade entre a pessoa e sua estrutura essencial. A estrutura da pessoa não é a pessoa, mas apenas aquilo que ela possui e aperfeiçoa com suas ações.

Embora indefinível, o núcleo do que constitui a pessoa pode ser designado como uma realidade ascensional, na qual o dinamismo operativo ultrapassa qualquer forma de concepção objetivadora, que tente restringir a pessoa ao domínio da simples facticidade (GONZALES, 2008, p. 56).

Nesse sentido, a melhor maneira de se caracterizar o esse pessoal seria expressá-lo em termos donativos, conforme o fizeram alguns estudiosos contemporâneos, a partir das considerações metafísicas de Leonardo Polo, que considera as realidades criadas (nas quais há a distinção entre a essência e o ato de ser) como dadas, vez que não se constituem como parte do Absoluto, nem estão totalmente independentes e alheias ao seu poder. É o que expõe Falgueras, ao situar a pessoa como doadora (ato de ser) de dons (perfeições que enriquecem sua essência):

\begin{abstract}
A pessoa é constituída mais pelo dar-se do que pelo ter. Precisamente se o ser consiste na doação, em dar, há espaço para uma explicação que é muito mais adequada do que outra no nível especulativo, posto que o que é ser específico não é ter, mas dar, e o que foi dado ao ser humano, somente pode ser completado no dar, no dar-se: ser é dar (Gonzales, 2008, p. 58).
\end{abstract}

Podemos ver aqui um desenvolvimento metafísico que é, ao mesmo tempo, esclarecedor e coerente com a posição de Henrique Vaz a respeito da noção de pessoa. Com efeito, para o filósofo brasileiro, conforme expusemos, o ser pessoal pode ser expresso dialeticamente pela síntese unificadora e dinâmica da oposição entre essência (o ser que é) e existência (o ser que se torna ele mesmo), no qual a tarefa de realizar a própria vida "é assumida pelo homem sob o estímulo permanente do aguilhão metafísico que o impele a ser mais" (VAZ, 1992, p. 224). Tal realização somente é possível porque há, na pessoa, uma radical abertura ontológica que se efetiva através das relações que estabelece com o mundo, com outros sujeitos e com o Absoluto. Essa abertura, que é também doação, se realiza através dos atos de conhecimento e de amor. 
Portanto, a noção de pessoa como uma totalidade una, dinâmica e aberta, tal como proposta por Henrique Vaz, parece estar em sintonia com os desenvolvimentos contemporâneos metafísicos derivados a partir da concepção intensiva do ato de ser pessoal. 


\section{Capítulo 3: A resposta de Henrique Vaz à negação humeana da identidade pessoal}

Estabelecidas as posições de David Hume e Henrique Vaz acerca do tema da pessoa e sua respectiva identidade, bem como os pressupostos filosóficos que permitiram enquadramentos tão distintos, passemos a estabelecer uma comparação mais direta, a fim de esclarecermos até que ponto a Antropologia Filosófica do pensador brasileiro consegue oferecer uma resposta consistente ao problema da identidade pessoal levantado por Hume.

Conforme pudemos assinalar no primeiro capítulo, Hume nega a existência das substâncias (HUME, 2009, p. 40) e, dentre elas, dos sujeitos pessoais. O ceticismo de Hume o leva a admitir como certa apenas a existência das nossas impressões e ideias, com independência de eventuais objetos dos quais possam provir (HUME, 2009, p. 113), bem como de um sujeito que as pense (HUME, 2009, p. 283). Para Hume, sequer temos a impressão ou a ideia de um "eu" permanente, visto que toda ideia deriva de uma impressão e todas as impressões são variáveis e inconstantes (HUME, 2009, p. 284). Negada a permanência de um suposto "eu", Hume afirma que as mentes não são mais do que feixes de impressões que se sucedem indefinidamente (HUME, 2009, p. 285), sendo que a tendência a atribuir identidade a nós mesmos ou a objetos extramentais não passa de uma ficção produzida pela associação de ideias na imaginação (HUME, 2009, p. 288), através da projeção mental de semelhanças obtidas pela memória a partir de impressões anteriores (HUME, 2009, p. 293).

O núcleo argumentativo de Hume para negar a identidade pessoal consiste na observação de que os objetos extramentais estão em contínua mudança em sua composição material, quer isso se dê de maneira abrupta e o percebamos imediatamente, quer isso ocorra de maneira tão gradual que somente nos damos conta ao final do processo (HUME, 2009, p. 290). Hume dirá que a mesma carência de identidade e permanência ocorre nos processos mentais: nossas percepções são sempre distintas, quer o percebamos ou não. E da mesma forma que atribuímos mentalmente uma permanência e identidade inexistentes nos objetos do mundo real, da mesma forma tendemos a atribuir uma permanência e uma identidade a nós mesmos, a modo de ficção (HUME, 2009, p. 292). 
A visão do homem contida na Antropologia Filosófica de Henrique Vaz se contrapõe à proposta humeana de dissolução da identidade pessoal numa sucessão de impressões distintas. Com efeito, Henrique Vaz (2009, p. 8) propõe o resgate de uma visão unitária do microcosmo humano, que não deixe de lado nenhuma de suas dimensões estruturais e que possa abarcar as diversas contribuições das ciências experimentais, sem que o próprio homem seja reduzido por elas. Essa visão unitária é proposta pelo filósofo brasileiro através do método dialético de síntese da multiplicidade na unidade, no qual a categoria filosófica da pessoa aparece como termo final que contém articuladas todas as demais categorias que descrevem o homem em suas múltiplas facetas ontológicas.

A proposta de Henrique Vaz apresenta a pessoa humana como uma totalidade una, dinâmica e aberta ao real, manifestamente diversa da dissolução do sujeito numa multiplicidade de impressões sucessivas e independentes da realidade, tal como apresentado pelo empirismo cético de Hume.

Apesar da evidente oposição a uma concepção empirista do homem, a Antropologia Filosófica de Henrique Vaz não tem como objetivo primordial estabelecer críticas e argumentos contrários à visão cética e fragmentadora do sujeito humano, nem se detém a analisar e apresentar contrarrazões à negação da identidade pessoal feita por Hume. Pelo contrário, a proposta do filósofo brasileiro é mais propositiva do que crítica e argumentativa, apresentando-se como uma alternativa às duas formas mais em voga de conceber o tema do sujeito na filosofia moderna, quais sejam: a unidade da consciência-de-si e a pluralidade das representações do "eu" (VAZ, 1992, p. 195).

Todavia, embora não tenha por escopo oferecer uma resposta cabal à negação da identidade pessoal proposta por Hume, não se pode negar que há, na proposta do homem que Henrique Vaz oferece como alternativa para as aporias do pensamento filosófico da modernidade, elementos abundantes para uma crítica satisfatória. Dentre esses elementos destacamos três, que pensamos representar bem o alcance da proposta antropológica de Henrique Vaz e que podem ser usados como contraponto para argumentar contra a negação da identidade pessoal.

O primeiro deles é a proposta de concepção do homem como razão e liberdade, duas propriedades das quais não se pode abrir mão, seja para negar, seja para duvidar, uma vez que o ato de negá-las ou de duvidar delas as supõe.

Nesse sentido, Henrique Vaz (1998, p. 218) menciona o argumento da redarguição, utilizado por Aristóteles na Metafísica para silenciar os negadores do princípio 
da não contradição, e o aplica àqueles que negam a existência de um sujeito. Assim, da mesma forma que a defesa da negação do princípio da não contradição já supõe implicitamente o seu uso, também o ato de negar ou meramente questionar a existência de um sujeito já o supõe, enquanto autor da negação ou do questionamento.

Assim como a dúvida ou a negação do sujeito, supõe um autor da dúvida ou da negação, também um eventual erro na suposição da própria existência supõe um autor do equívoco. Portanto, quando Hume defende que a ideia de um sujeito é uma ficção, devemos nos perguntar quem está sob o efeito dessa ilusão, ou seja, a quem pertence essa ficção.

Essa implícita contradição é típica dos pensadores empiristas, que se colocam num plano epistemológico acima daquilo que é empiricamente atestável, ao mesmo tempo em que reduzem a realidade, ou ao menos a certeza, ao nível da observabilidade. Ao fazerem isso, colocam-se numa perspectiva metafísica para negar a existência dessa dimensão da realidade, ou ao menos para pô-la em dúvida, o que é evidentemente contraditório. Seria o mesmo que subir numa escada e, permanecendo em cima dela, desde a altura do seu último degrau, negar ou duvidar da existência da própria escada. Nesse mesmo sentido, Hume se contradiz ao tentar refutar uma série de aspectos metafísicos da realidade, tais como a substancialidade, a causalidade, a identidade ou a existência de sujeitos. Também nessa contradição se inclui a negação da universalidade dos conceitos, dado que qualquer tipo de negação supõe ultrapassar o plano da particularidade para se colocar no da universalidade. Com efeito, somente podemos negar algo na medida em que o situamos dentro de uma moldura conceitual mais ampla para além dos limites particulares daquilo que queremos negar ${ }^{8}$. Além do mais, poderíamos perguntar: a negação da universalidade dos conceitos é uma ideia de alcance universal? E isso não é contraditório?

Talvez se pudesse afirmar, em defesa de Hume, que ele não negou a existência de um sujeito das impressões ou ideias, mas apenas sua identidade como sujeito, isto é, sua permanência ou duração ao longo do tempo. Ocorre que, ao limitar nosso conhecimento às

\footnotetext{
${ }^{8}$ Nesse sentido, Leonardo Polo assinala a perspectiva epistêmica intrinsecamente generalista subjacente a cada negação, perspectiva essa que denota a imaterialidade do pensamento capaz de conceber a negatividade. Nas palavras do autor: "Para negar é necessário manter nossas ideias separadas das coisas concretas, porque a negação se faz sempre no geral: negar é estar ante algo suprimido. Com o não estamos eliminando teoricamente tudo o que um algo tenha de real particular, e nos mantemos de um modo constante nessa eliminação. [...] Dito de outro modo, o negativo é o geral comparado formalmente com o particular: se nega separando o geral, destacando-o, do contrário, não se nega (teoricamente). [...] Se o ato de entender não fosse independente de toda a temporalidade, não poderíamos pensar o negativo, que está inteiramente separado do tempo, pois nem sequer é. Como seria possível pensar o que não é? Somente se há em mim algo atemporal.” (POLO, 2003, p. 197-198, tradução nossa).
} 
impressões e ideias e ao desvinculá-las dos seus respectivos sujeitos (HUME, 2009, p. 283), Hume tornou equivalentes a negação da existência do sujeito com a negação da sua identidade ao longo do tempo, afinal as ideias ou impressões gozam de independência de uma consciência que as pense, seja essa consciência permanente ou simplesmente inexistente.

Além disso, negar identidade aos objetos extramentais, aos sujeitos pessoais ou mesmo às impressões, é o mesmo que negar a existência desses objetos, desses sujeitos ou dessas impressões, pois se dado sujeito ou dado objeto ou determinada impressão não permanece idêntico a si mesmo, isso significa que tal entidade não contém um mínimo de duração, uma vez que esta supõe, ainda que mínima, uma noção de identidade. Ora, não contendo um mínimo de duração e de permanência, tal como afirmado por Hume ${ }^{9}$, o sujeito ou o objeto deixam de existir. Ademais, resta problemática a própria noção de mudança, a qual supõe certa identidade, dado ser sua relativa negação. Em outras palavras, se nada permanece, nada muda, pois a mudança exige a passagem de determinada espécie de identidade para outra forma de identidade. Abolida a identidade, resta abolido o movimento. Por essa razão, o princípio metafísico da identidade do ser, segundo o qual o ser é idêntico a si mesmo, não pode ser abolido, assim como o princípio da não contradição.

Assim, a partir da experiência do sujeito que se interroga a si mesmo, da qual nasce, segundo Henrique Vaz, a antropologia filosófica, surge o primeiro elemento de crítica à negação da identidade pessoal.

Enfim, complementando o que até aqui consideramos, poderíamos inclusive contestar a identidade do próprio Hume, bem como a unidade e a coerência do seu extenso Tratado. Com efeito, se Hume estivesse correto, poderíamos afirmar que o filósofo que começou a escrever o Tratado da Natureza Humana não permaneceu o mesmo, sendo tal obra de autoria de uma sucessiva infinidade de sujeitos, ou ainda uma obra de um sujeito inexistente. Ademais, as impressões e ideias que levaram Hume a escrever seu Tratado não seriam as mesmas ao longo do tempo em que as páginas foram escritas, não podendo haver qualquer nexo semântico que as interligasse num todo coerente. Por essa razão, Henrique Vaz, na esteira do que propunha Aristóteles, apresenta ao cético um convite ao silêncio como única

\footnotetext{
${ }^{9} \mathrm{Na}$ passagem em que compara a mente a um teatro onde desfilam ininterruptamente sucessivas impressões, Hume nega, de maneira clara e radical, qualquer vestígio de identidade de um sujeito subjacente ao movimento das impressões, conforme é possível atestar no seguinte trecho: "Não há um só poder na alma que se mantenha inalteravelmente o mesmo, talvez sequer por um instante... Nela [na mente] não existe, propriamente falando, nem simplicidade em um momento, nem identidade ao longo de momentos diferentes, embora possamos ter uma propensão natural a imaginar essa simplicidade e identidade." (HUME, 2009, p. 285).
} 
possibilidade de conduta. Ora, na medida em que tudo é posto em dúvida, até mesmo a identidade do sujeito da dúvida, então nada mais cabe afirmar, negar ou questionar, restando apenas uma alternativa filosoficamente coerente: a mudez do vegetal (VAZ, 1998, p. 218).

A noção de intencionalidade pode ser arrolada como um segundo elemento presente na Antropologia Filosófica de Henrique Vaz que serve como crítica da negação da identidade pessoal.

Para Henrique Vaz, a intencionalidade transborda em toda a estrutura e relações que compõem a essência do homem. O corpo próprio possui um caráter simbólico e intencional (VAZ, 1998, p. 175), que aponta para a inteligência espiritual que o informa. Também o espírito em sua própria constituição ontológica aponta para fora de si, numa abertura ao horizonte ilimitado do ser (VAZ, 1992, p. 223), abertura essa que se manifesta na insaciabilidade da sua inteligência e liberdade, bem como na capacidade de conceber algo que está para além da imediatez de sua experiência, capacidade que supõe certa afinidade com a transcendência (VAZ, 1992, p. 97), consoante assinalamos ao descrever a categoria da relação de transcendência.

Por outro lado, também tivemos oportunidade de constatar que, ao negar a identidade pessoal, Hume afirmou que a mesma é uma ficção, produzida a partir de múltiplas percepções distintas, as quais, em razão de certas relações de semelhança, são reunidas pela nossa imaginação sob a influência da memória (HUME, 2009, p. 293). Essa sequência de pluralidade de ideias e representações do "eu" evidenciaria sua não referência a uma realidade única e permanente.

Acontece que a realidade a que se referem as múltiplas ideias e representações do "eu" não necessita necessariamente ser negada ou multiplicada. Embora possam haver múltiplas e variadas representações do próprio "eu", isso não implica na necessidade do sujeito dessas representações não existir, ou ser múltiplo, pois cada representação, ainda que seja diferente da anterior, não contém plenamente o significado da realidade a que se refere. Nesse sentido, podemos destacar duas razões pelas quais é compatível a pluralidade de representações mentais de um objeto e sua unidade extramental.

A primeira delas consiste na constatação de que a realidade sempre ultrapassa as limitações das nossas impressões e conceitos. Manifestação dessa irredutibilidade da realidade às nossas categorias mentais é a dualidade inerente aos nossos atos cognitivos, revelada no seu caráter de intencionalidade. 
Tal intencionalidade, conforme vimos ao tratar da categoria da pessoa, consiste na inerente referência de qualquer ato cognitivo a um objeto distinto de si: quem pensa, vê ou sente, sempre pensa em algo, vê algo ou sente algo, não subsistindo um puro ato de pensar, ver ou sentir. É evidente, portanto, a permanência de uma dualidade necessária e inerente ao próprio ato cognitivo: de um lado o sujeito que pensa, do outro o objeto pensado. Um nunca se identifica plenamente com o outro, sendo ambos mutuamente irredutíveis. Nesse sentido, ainda quando reflete sobre si, o pensamento pensado é incapaz de realizar o ato de pensar, mantendo-se sempre a dualidade. Portanto, ainda que pense sobre si mesmo, o sujeito, nessa relação de conhecimento, se apresenta como objeto perante si, e essa condição de objeto o reduz, não refletindo plenamente o que ele é em si mesmo, dado que deixa de fora sua sujeitualidade. Em outras palavras, o sujeito pensado não pensa e nem é capaz de conferir efetividade ontológica a si ou a seus atos.

Pois bem, à luz da intencionalidade do ato de conhecer, resta justificada a compatibilidade entre a unidade do sujeito e suas múltiplas representações, sem que isso implique na ausência de adequação veritativa entre cada representação e o sujeito real por ela significado.

Além disso, uma segunda razão pela qual é compatível a multiplicidade de representações mentais com a unidade real dos objetos consiste na diferença entre os conceitos e suas respectivas representações sensíveis. Aqui parece residir boa parte do equívoco de Hume, que não leva em conta essa distinção. Isso porque, conforme vimos ao tratar da categoria da pessoa em Henrique Vaz, no ato de conhecimento há uma apreensão da forma do objeto conhecido. O conceito elaborado a partir dessa apreensão sempre vem acompanhado de uma imagem particular, a qual é variável. Assim, quando penso no conceito de água, esse conceito virá acompanhado de alguma imagem particular, variável no tempo e de pessoa para pessoa. Posso acompanhar o conceito de água com uma imagem de um copo de vidro repleto de água, posso pensar na grafia da palavra água, posso pensar numa particular imagem de algum rio no qual nadei, por exemplo. Embora essas imagens sejam variadíssimas, o conceito pensado será sempre o mesmo e isso pode ser aferido pelo seu uso na linguagem, a partir da minha habilidade de construir com espontaneidade e corretamente uma série de proposições coerentes contendo a palavra "água”.

Por outro lado, a imagem particular, embora variável, sempre acompanha o conceito, o qual, uma vez apreendido, necessita da imagem para ser pensável no ato do pensamento. Sem uma associação a qualquer imagem, o conceito jamais seria pensável. 
Assim, quando Hume nega a universalidade dos conceitos, os substitui por imagens particulares, que ele chama impressões e ideias, e daí provém seu equívoco, pois ao perceber que o pensamento sobre um objeto é sempre acompanhado por uma variedade de impressões ou ideias particulares e distintas, conclui que a unidade e a identidade do objeto são pura ficção.

Em contrapartida, poderíamos alegar, em defesa de Hume, que o filósofo escocês intuiu a irredutibilidade do sujeito a uma apreensão meramente conceitual, ou, para utilizar uma expressão de Henrique Vaz, o sujeito não poderia ser plenamente descrito em termos eidéticos. Nesse ponto poderíamos conciliar Hume com Henrique Vaz, na medida em que ambos admitem que o sujeito nunca possa ser plenamente descrito por uma ideia, conceito ou impressão. Porém, conserva-se uma considerável diferença de pensamento entre os referidos filósofos, na medida em que Hume conclui que o sujeito não existe ou, quando muito, não permanece na duração do tempo, enquanto Henrique Vaz continua a defender a unidade do “eu” na pluralidade de suas manifestações (VAZ, 1992, p. 227).

Enfim, podemos estabelecer um último paralelo da noção de intencionalidade como inescapável referência a algo extrínseco ao próprio ato de pensar, com a crítica apresentada no final do primeiro capítulo do presente trabalho. Segundo essa crítica, não se pode conceber uma impressão ou mesmo determinada forma de sensação que se dê à margem de uma consciência, ainda que elementar. Uma sensação ou impressão plenamente independente da consciência, já não seria uma impressão ou sensação. Desta forma, dentro da própria noção de impressão ou sensação, subjaz uma intrínseca e inseparável referência à consciência do sujeito.

Finalmente, um terceiro e último elemento que destacamos na Antropologia Filosófica de Henrique Vaz que pode ser utilizado como fonte de crítica para a negação humeana da identidade pessoal é a noção de forma, a qual, junto com a matéria, é igualmente um princípio constitutivo da realidade.

Segundo já tivemos a oportunidade de mencionar, o centro do argumento de Hume contra a identidade pessoal decorre da negação da unidade da substância a partir da observação da constante mudança dos elementos materiais que compõem tanto os seres inanimados como os seres vivos. Nesse sentido, na medida em que as coisas estão submetidas a uma série de mudanças materiais contínuas mais ou menos graduais, não se poderia assinalar uma unidade e uma identidade de fato nos objetos, a não ser a modo de ficção. 
Transpondo essa constatação para a questão do sujeito, Hume dirá que a mesma carência de identidade e permanência ocorre nos eventos mentais: nossas sucessivas percepções, que são sempre distintas, não estão vinculadas a um sujeito diferente delas. E, do mesmo modo que atribuímos mentalmente uma permanência e identidade que não existem realmente nas coisas, assim também tendemos a atribuir uma permanência e uma identidade a algo que ligue essas percepções (HUME, 2009, p. 292).

A nosso ver, a crítica de Hume não subsiste ao conceito de forma, entendido como um coprincípio constituinte de todas as coisas, conforme pudemos esclarecer no subcapítulo referente à teoria hilemórfica. Com efeito, a forma é a responsável, em última instância, pela unidade e pela permanência da identidade de cada ente consigo mesmo (VAZ, 1992, p. 217) ainda que se constate uma série de mudanças nos elementos materiais que o compõem.

A forma possui uma função instrumental na composição de qualquer ente, função semelhante à que o ato possui em relação à potência que o recebe. Sua função é ser o ato daquela porção quantitativa por ela informada, unificando a multiplicidade de seus elementos em direção a determinado fim (VAZ, 1992, p. 248, nota $n^{\circ}$ 135). A unificação dos componentes materiais de um ente em torno a um fim comum confere a esse ente uma determinada configuração significativa, objeto de percepção imediata pela nossa inteligência. É o caso de uma melodia musical, que pode ser reconhecida, ainda que haja uma profunda alteração nos elementos que a compõem. Também no caso de um rio, apesar do fluxo constante de milhões de moléculas de água distintas entre si, se pode perceber uma determinada configuração significativa, responsável pela identidade daquele rio.

A configuração significativa das entidades do mundo natural não é fabricada pela nossa mente à título de ficção, sendo antes uma realidade que compõe a estrutura das coisas, conferindo-lhes, a partir de dentro, uma unidade e uma identidade de significado.

Nos seres vivos, mais do que nos seres inanimados, essa formalização é ainda mais evidente, na medida em que é mais intensa e, portanto, mais significativa e perceptível. Com efeito, nos seres vivos a forma exerce uma função de autorregulação, constituindo-os como sistemas abertos autorregulados, apesar do incessante intercâmbio dos seus componentes materiais com o meio, além de exercer a função de matriz geradora de um padrão que se expande em seus descendentes.

A relação de unidade estrutural entre matéria e forma (VAZ, 1998, p. 223) não pode ser compreendida em termos de justaposição de dois elementos previamente distintos, mas sim como uma mútua relação de copertença entre o determinante e o determinado, nos 
mesmos moldes em que a visão é o ato do olho, sendo irredutível à mera soma e junção de seus componentes materiais.

Nos seres humanos a formalização atinge um grau ainda mais intenso, permitindo aos indivíduos dessa espécie apreender intencionalmente as formas dos outros seres, através da atividade de conhecimento. $\mathrm{E}$, diferente de outros graus de formalização encontrados nos demais seres vivos, a formalização operada pelo ato do conhecimento é, conforme assinalamos anteriormente, uma atividade não orgânica, não cronometrável e simultânea, que ultrapassa o âmbito do material, marcado pela distensão espaçotemporal.

Pois bem, feitos esses esclarecimentos e considerações, podemos responder ao problema da unidade e permanência dos objetos do mundo levantado por Hume, assinalando que a fonte da unidade é dada pela forma, ato dos corpos materiais, que lhes confere significado e que permite à nossa mente distinguir sua identidade frente à multiplicidade $\mathrm{e}$ frente à eventual sucessão dos seus componentes materiais.

De maneira semelhante, podemos responder o problema de conjugar a pluralidade de eventos mentais com a unidade do sujeito desses eventos. Isso porque, do mesmo modo que cada objeto material do mundo não pode ser reduzido à mera soma de seus componentes materiais, também nossa identidade psíquica, nosso "eu”, não é redutível a uma sequência temporal de eventos mentais. Com efeito, além de termos constatado que os atos referentes à ordem do conhecimento ultrapassam a distenção espaçotemporal, sendo simultâneos e instantâneos, prejudicando a concepção da mente como um processo sequenciado, também constatamos que a realidade mais íntima de cada ser humano, da qual emerge sua unidade e identidade, não é redutível ao somatório de suas impressões ou de seus componentes materiais.

Por fim, visando tornar mais palpável a natureza da forma, remontamos à comparação feita no subcapítulo em que expusemos a teoria hilemórfica, no qual estabelecemos um paralelo entre a forma e os programas computacionais, caracterizados pelas funções lógicomatemáticas que autorregulam os componentes materiais das máquinas. Assim, do mesmo modo que o programa computacional é uma idealidade capaz de desempenhar uma série de funções lógicomatemáticas usando uma estrutura material acrescida de energia, também as formas dos entes naturais preenchem de unidade, identidade e significado a variedade dos elementos materiais por ela informados.

Ora, se aceitássemos o redutivismo de Hume, que limita os objetos e as mentes ao somatório dos elementos materiais ou das impressões que os compõem, teríamos de afirmar 
que os programas computacionais não existem ou não passam de uma simples ilusão, sendo redutíveis apenas aos seus componentes materiais, o que é absurdo. Com efeito, devemos recordar que os componentes materiais de um sistema cibernético desempenham uma função absolutamente secundária, dado que essa ciência tem por objeto as funções lógicomatemáticas dos seus sistemas (ARREGUI; CHOZA, 1995, p. 119-120). Portanto, negar a existência da forma como um coprincípio constituinte dos entes materiais seria tão equivocado quanto reduzir um computador ao seu maquinário físico.

Ante todo o exposto, pudemos ver neste capítulo a presença de três elementos contidos na Antropologia Filosófica de Henrique Vaz: i) a visão do homem como um sujeito dotado de razão e liberdade; ii) a concepção do homem como um ser dotado de intencionalidade em sua estrutura e em seus atos de conhecimento; iii) a noção de forma como um coprincípio constituinte da realidade, junto com a matéria.

Tais elementos possibilitam, conforme pudemos constatar, uma crítica bem fundamentada à negação da identidade pessoal feita por Hume, além de apontarem para uma visão filosoficamente mais madura do ser humano. 


\section{Conclusão}

Ao longo da dissertação vimos que a negação que Hume faz da identidade pessoal decorre do seu empirismo antimetafísico, que se apresenta cético quanto ao conhecimento da existência de qualquer realidade para além das próprias percepções. Hume nega a unidade e a identidade ao longo do tempo dos entes do mundo natural, afirmando ser ilusória a substancialidade que atribuímos às coisas, fruto da associação de ideias simples unificadas pela imaginação.

Nesse mesmo sentido, não haveria um sujeito distinto e permanente que unificasse nossas diversas percepções, podendo nossa mente ser reduzida a um feixe de sucessivas impressões. No apêndice que escreveu e incorporou ao final do seu Tratado, Hume manifestou sua insatisfação quanto ao seu próprio posicionamento a respeito do tema da identidade pessoal, sem, todavia, apontar de maneira clara as razões da sua insatisfação, uma vez que afirmou não conseguir abrir mão dos princípios que o levaram àquela conclusão.

As causas da insatisfação de Hume foram objetos de diferentes opiniões por parte de seus comentadores e críticos, conforme pudemos constatar, a partir de alguns exemplos trazidos. Através desses comentários, foi possível concluir que a insatisfação de Hume possuía bons fundamentos, tendo em vista as lacunas apontadas dentro do seu próprio sistema filosófico, além das contradições referentes aos seus pressupostos céticos e empiristas.

Em contraposição à diluição do sujeito num fluxo de impressões, expusemos a proposta de Henrique Vaz, que, partindo do método dialético, apresenta a categoria da pessoa como síntese e vértice conceitual do discurso antropológico, numa unidade dinâmica de oposição entre essência - estrutura espiritual e psíquicossomática preenchida pelas relações de objetividade, intersubjetividade e transcendência - e existência.

Durante a exposição da proposta antropológica de Henrique Vaz, pudemos destacar uma série de paralelos com outras vertentes contemporâneas, tais como as de Jacinto Choza, Ricardo Yepes, Tomás Alvira, Norris Clarke e outros. Tais autores têm buscado apresentar a riqueza e a atualidade das reflexões da tradição metafísica de Aristóteles e Tomás de Aquino, dotadas de um forte potencial de contribuição para a antropologia filosófica, especialmente através do conceito de pessoa. 
A proposta de Henrique Vaz é mais expositiva do que argumentativa, não estando focada em combater diretamente o empirismo ou o ceticismo. Apesar disso, pudemos fazer, na última parte desta dissertação, uma comparação mais direta entre Henrique Vaz e David Hume, destacando três elementos contidos na proposta do filósofo brasileiro capazes de oferecer uma resposta satisfatória ao problema da identidade pessoal formulado pelo pensador escocês. Esses três elementos são: a concepção do homem como um ser de razão e de liberdade; sua estrutura espiritual e psicossomática dotada de intencionalidade; e o resgate da noção aristotélica de forma como fonte de unidade e estruturação semântica do homem e da realidade.

Ao final dessa breve síntese do presente trabalho, gostaríamos de apontar alguns possíveis paralelos entre a proposta de uma antropologia filosófica centrada no conceito de pessoa apresentada por Henrique Vaz, com outras duas propostas contemporâneas, que também levam em conta a mesma categoria filosófica. A nosso ver, esses possíveis paralelos poderiam ser objeto de futuras pesquisas, que transcendem o escopo desta dissertação.

A primeira proposta que trazemos é a de J. V. Arregui e J. Choza (1995, p. 424457), que apresentam o homem a partir de quatro perspectivas antropológicas complementares, podendo ser classificadas em quatro planos: metafísico, biopsíquico, existencial e sociocultural. Tal divisão, longe de fragmentar a reflexão antropológica, permite uma visão unitária em permanente diálogo com as diferentes ciências do homem, numa síntese que seja unificadora sem ser reducionista. Segundo os referidos autores, os quatro planos poderiam ser agrupados em dois principais: um metafísico e o outro existencial, dandose neste último as perspectivas biopsíquicas e socioculturais.

Nessa proposta, o conceito de identidade possui um sentido análogo, de acordo com a perspectiva sob a qual se analisa o sujeito humano. No plano metafísico, a identidade do sujeito é dada já desde o início, enquanto no plano existencial a identidade deve ser construída, a título de tarefa, sendo que tal construção se faz por meio de constantes processos de individualização, que ocorrem simultaneamente em distintos planos. No plano biopsíquico, esse processo ocorre especialmente durante o processo embrionário de tessitura do organismo. No sociocultural, a individualização se dá ao longo do processo educativo e de socialização. No existencial, através dos atos livres que permitem ao indivíduo modelar a sua própria biografia.

As sucessivas determinações qualificam o sujeito metafísico, embora este não se reduza a elas. Com efeito, o sujeito metafísico é anterior a tais determinações, sendo seu 
suporte ontológico, sua condição de possibilidade. Segundo Arregui e Choza, num sentido semelhante, Wittigenstein (1968, p. 111 e 112, parágrafos 5.632 e 5.633) chamou a atenção para essa irredutibilidade empírica do "eu", destacando que este não é um acontecimento, nem se reduz ao conjunto de fatos empíricos que constituem a vida e o mundo, sendo antes um limite do mundo. E, visando ilustrar essa distinção, Wittigenstein estabeleceu uma comparação com a relação entre o olho e o campo visual: este é visível, enquanto aquele não.

Como evidências dessa irredutibilidade do "eu" a um conjunto de vivências, Arregui e Choza apresentam as experiências de patologias de múltipla personalidade ou de esquizofrenia. De fato, caso o "eu" fosse apenas uma unidade estrutural de atos e vivências, conforme propôs Scheler, não seria possível haver uma desconexão entre o "eu" e a vida, tal como se dá nos tipos de patologia assinalados. Essa desconexão deixa evidente que há um sujeito real por trás das múltiplas personalidades, ao menos num sentido de um corpo humano vivo.

Embora irredutível ao conjunto de atos e vivências, o sujeito metafísico proposto por Arregui e Choza não é um puro substrato inalterável, uma espécie de pressuposto lógico; do contrário, tal concepção não se apartaria do que Hume chamou de ficção. Para os referidos autores, o "eu" metafísico, que pode ser identificado com o conceito boeciano de pessoa, é o fundamento real dos nossos atos e vivências, sendo, inclusive, por eles modificado, embora não se possa dizer que essa modificação seja capaz de alterar sua identidade. Poderíamos expressar essa concepção afirmando que o "eu" é sempre ele mesmo, embora não seja sempre o mesmo. Ou seja, o "eu” do plano metafísico, ainda que individual, é uma realidade aberta e indeterminada, que se vai preenchendo e determinando no plano da existência.

A proposta antropológica de conjugação de diferentes planos unidos pela referência ao mesmo sujeito metafísico, feita por Arregui e Choza, permite compatibilizar, na unidade de um mesmo sujeito, a pluralidade de suas manifestações e determinações no plano da existência. Isso também foi proposto por Henrique Vaz, na forma do que expusemos ao longo da dissertação, ao assinalar que o filósofo brasileiro concebeu a pessoa como identidade na oposição entre essência e existência.

Além do paralelo com a Antropologia Filosófica de Henrique Vaz, a proposta de Arregui e Choza de abordagem do sujeito em quatro planos distintos - metafísico, biopsíquico, existencial e sociocultural - permite identificar a razão da contradição no pensamento de Hume referente à identidade pessoal. Isso porque, na forma do que já vimos quando mencionamos a crítica feita por María Elósegui, Hume se contradisse ao negar a existência e a 
identidade do eu, ao mesmo tempo em que o admitia para explicar o mecanismo da paixão do orgulho. Ora, se Hume tivesse em conta a distinção entre os distintos planos, poderia evitar a contradição na qual incorreu, na medida em que tal abordagem permite reunir as sucessivas determinações que individualizam o sujeito na unidade irredutível do plano metafísico. Em outras palavras, é possível compatibilizar as mudanças na existência do sujeito, sem que seja necessário negar sua unidade e identidade.

A segunda proposta contemporânea que trazemos, além de inovadora numa série de pontos, apresenta um paralelo com a visão de pessoa em Henrique Vaz. Trata-se da proposta formulada por Leonardo Polo ${ }^{10}$, na qual se propõe uma antropologia transcendental a partir de uma renovação metodológica sugerida pelo autor denominada como abandono do limite mental.

Através do método do abandono do limite mental, Polo pretende superar o pensamento objetivador para chegar ao ser extramental. Seu método apresenta-se como uma decorrência e desenvolvimento da distinção entre essência e ser, inerente à filosofia da criação, distinção também presente na concepção vaziana dos seres pessoais, tal como apontamos ao assinalar a primazia ontológica do ato de ser e seu caráter intensivo na constituição da pessoa.

O abandono do limite mental constata a infinitude operativa da inteligência, a qual, ao se deparar com um determinado objeto intencional, torna-se consciente desse limite. Ora, a consciência do limite somente é possível através de uma perspectiva superior, a partir da qual se vê o limite. Nas palavras de Polo: "se a inteligência nota que não pode conhecer mais, esse advertir 'o não conhecer mais' é, por sua vez, um conhecer, e através do notar que ‘não conhece mais', pode ir mais além." (POLO apud FALGUERAS, I.; GARCÍA, J. A.; YEPES, R., p. 43, tradução nossa). Ou, em outras palavras do próprio Polo: “a inteligência não termina, mas sim prossegue objetivando qualquer obstáculo com o qual se depare e, com isso, o supera: quando se entende algo, se possui o entendido e se continua a entender. Caso se possua a compreensão de que não se pode entender, continua a entender precisamente a partir disso.” (POLO apud FALGUERAS, I.; GARCÍA, J. A.; YEPES, R., p. 43, tradução nossa).

Assim, o conhecimento objetivo do limite permite superá-lo. Isso significa que o ato de conhecimento do limite supõe a existência de algo para além da intencionalidade do

\footnotetext{
${ }^{10}$ As principais linhas da antropologia filosófica de Leonardo Polo e a exposição do método do abandono do limite mental encontram-se dispersas em várias de suas obras, dentre as quais destacamos: Antropología Transcendental; Curso de Teoría del Conocimiento; Presente e Futuro del Hombre. Essas e boa parte de suas obras encontram-se disponíveis ao público no site: $\underline{\text { www.iterhominis.com. }}$
} 
objeto conhecido. Supõe também a existência do sujeito que conhece, sujeito que sempre escapa aos limites de um enquadramento objetivante. O "eu" está sempre para além daquilo que é pensado. O "eu" é aquilo a que o pensado se refere existencialmente. Não é que o sujeito seja incapaz de autoconhecimento, mas apenas que esse autoconhecimento é limitado, conforme sintetizou Polo ao destacar que "o eu pensado não pensa". Dessa forma, resta sempre de fora da operação de conhecimento uma espécie de excesso ontológico do sujeito pensante, sempre irredutível ao pensamento. Polo assim o sintetizou: “[Se] não posso de nenhuma maneira comunicar meu caráter de pensante ao que penso, a realidade não está no pensado, e, portanto, o sujeito não é uma operação." (POLO apud FALGUERAS, I.; GARCÍA, J. A.; YEPES, R., p. 54-55, tradução nossa). Polo chamou esse excesso ontológico de además, um estar para além daquilo que se concebe, uma superabundância, uma irrestrição.

A distinção entre a operação mental e o sujeito existencial da qual ela depende é uma reverberação do princípio metafísico segundo o qual o ser precede o agir. Portanto, há uma diferença entre o pensar e o ser do homem (FALGUERAS, I.; GARCÍA, J. A.; YEPES, R., p. 57).

Uma questão que se poderia colocar é a seguinte: a exposição desse aspecto da doutrina de Polo é pensável, logo não caberia a distinção existencial entre a operação mental e o sujeito. Em outras palavras, se o excesso do sujeito transcende a intencionalidade do conhecimento, isso significa que tal excesso sequer pode ser concebido. Por essa razão, Polo propõe que a existência pessoal propriamente não se conhece intencionalmente, embora seja alcançável por outra via: a do acompanhamento (POLO apud FALGUERAS, I.; GARCÍA, J. A.; YEPES, R., p. 55). O acesso ao ser pessoal, isto é, ao sujeito, se dá, portanto, para além dos atos intencionais do conhecimento. Seu alcance se faz pela via do saber pessoal, um conhecimento transcendental que é irredutível aos atos intencionais.

De maneira análoga, se chega à liberdade transcendental. Com efeito, a liberdade transcendental também está para além de uma categorização, bem como de um aperfeiçoamento da vontade por meio do agir. Isso porque, enquanto a vontade deseja aquilo do que carece, por ser potência, a liberdade é doação, por ser ato. Portanto, a liberdade transcendental é prévia e superior à vontade, não podendo ser redutível ou mesmo aperfeiçoada pelos atos desta. Em outras palavras, a liberdade transcendental não pode ser entendida como tábula rasa que vai sendo ativada pelos atos da vontade, nem como a mera resultante do fortalecimento desta (SELLÉS, 2013, p. 83). 
Outra faceta transcendental da pessoa, junto ao conhecimento e à liberdade, é a coexistência. Esse terceiro transcendental da pessoa decorre do acesso ao ser extramental, ao que se chega pelo abandono do limite mental. Também o caráter ativo da liberdade transcendental, que se reflete na doação, manifesta que a pessoa não se encontra sozinha, não valendo a hipótese da pessoa única levantada pelo solipsismo.

Ou seja, a proposta de Polo, partindo do método do abandono do limite mental, pretende aceder aos transcendentais antropológicos, uma amplificação da ordem transcendental metafísica, onde se dá aos seres pessoais um tratamento próprio, especialmente no tocante à distinção entre essência e ato de ser. Nessa nova ordem transcendental, Polo indica algumas perfeições puras inerentes exclusivamente ao ato de ser pessoal, às quais chamou: conhecimento pessoal, liberdade pessoal, coexistência, amor pessoal, podendo ainda haver outros, umas vez que são facetas que se convertem mutuamente, tal como se dá com os transcendentais metafísicos (SELLÉS, 2013, p. 84).

A filosofia de Polo, ao constituir a pessoa no âmbito do ato de ser, desenvolve uma perspectiva para além do categorial, na qual se leva em conta a especificidade dos seres pessoais, refletindo de maneira mais perceptível seu excesso ontológico. Daí seu apelo à uma nova ordem transcendental: o âmbito do transcendental antropológico (LOMBO, 1996, p. 721-722).

A nosso ver, a Antropologia Filosófica de Henrique Vaz parece seguir, ao menos inicialmente, a mesma direção da proposta de Polo, ao ratificar a distinção entre essência e ser no âmbito da pessoa, além de destacar o dinamismo e a abertura como seus traços característicos. Tais traços são mais visíveis quando os situamos numa ordem transcendental própria, diante da qual a essência humana é possuída e capaz de ser aperfeiçoada pelo ato de ser (GONZALES, 2008, p. 58) uma instância transcendentalmente superior, indefinível em termos categoriais, caracterizada pelo excesso ontológico.

Além do mais, tal proposta permite que se conjugue a unidade e a permanência da pessoa com o intrínseco dinamismo do seu caráter donal, sem que seja necessário negar a sua identidade para afirmar a pluralidade de suas manifestações, tal como feito por Hume. 


\section{Referências Bibliográficas}

ALVIRA, Tomas; CLAVELL, Luis; MELENDO, Tomas. Metafisica. 5. ed. Pamplona: EUNSA, 1993.

ARISTÓTELES. Ética a Nicômacos. Brasília: Editora Universidade de Brasília, 1985.

ARISTÓTELES. Física. Disponível em:

$<$ https://drive.google.com/file/d/0BxAbmxL88uaJV2dLTVVVWnFSTTQ/edit?pref=2\&pli=1 >. Acesso em: 05 mar. 2016.

ARREGUI, J. Vicente; CHOZA, J. Filosofia del hombre. Una antropologia de la intimidad. 4. ed. Madrid: Ediciones Rialp, 1995.

CLARKE, Norris. Person and Being. Marquette University Press. Fourth Printing. Milwaukee, 1998.

COPLESTON, Frederick. Historia de la filosofía. Volume V. De Hobbes a Hume. 2. ed. Barcelona: Editorial Ariel, 1993.

CUYPERS, Stefaan. Hacia una concepción no atomista de la identidad personal. Revistas e Series UN. Anuario Filosófico, Pamplona, n. 26, p. 223-248, 1993. Disponível em: < http://dadun.unav.edu/bitstream/10171/639/4/1.\%20HACIA\%20UNA\%20CONCEPCI\%C3\% 93N\%20NO\%20ATOMISTA\%20DE\%20LA\%20IDENTIDAD\%20PERSONAL\%2c\%20ST EFAAN\%20CUYPERS.pdf>. Acesso em: 29 abr. 2015.

DE CARVAlHO, Olavo. David Hume e Thomas Reid. São Paulo: Editora É Realizações, 2007 (História Essencial da Filosofia. Aula 22). 
A existência do Eu. São Paulo: Editora É Realizações, 2007.

(História Essencial da Filosofia. Aula 23).

ELÓSEGUI, María. El descubrimiento del yo según David Hume. Revistas e Series UN. Anuario Filosófico, Pamplona, n. 26, p. 303-326, 1993. Disponível em: < http://dadun.unav.edu/bitstream/10171/644/4/6.\%20EL\%20DESCUBRIMIENTO\%20DEL\%2 0YO\%20SEG\%C3\%9AN\%20DAVID\%20HUME\%2c\%20MAR\%C3\%8DA\%20EL\%C3\%93 SEGUI.pdf >. Acesso em: 21 abr. 2015.

FAITANIN, Paulo. Acepção Teológica de 'Pessoa' em Tomás de Aquino. Revista Eletrônica Aquinate, Niterói, no 3, p. 47-58, 2006. Disponível em: $<$ http://www.aquinate.net/revista/edicao_atual/Artigos/03/a-acepcao-teologica\%20de-pessoaem\%20tomas\%20de\%20aquino.pdf >. Acesso em: 18 jun. 2015.

FALGUERAS, I.; GARCÍA, J. A.; YEPES, R. El pensamiento de Leonardo Polo. Cuadernos de Anuario Filosofico. Serie Universitaria, $n^{\circ} 11$. Servicio de Publicaciones de la Universidad de Navarra. S.A, Pamplona, 1994.

GARRETT, Don. Hume's Self-Doubts about Personal Identity. The Philosophical Review, Vol. 90, No. 3. Jul., 1981.

GILSON, Etienne. A existência na filosofia de S. Tomás. Trad. de Geraldo Pinheiro Machado, Gilda Lessa Mellilo e Yolanda Ferreira Balcão. São Paulo: Livraria Duas Cidades, 1962.

GONZÁLEZ, Ángel Luis. A metafísica tomista: interpretações contemporâneas. Trad. de Paulo Faitanin e Daniel Pêcego. Revista Eletrônica Aquinate, Niterói, nº 7, p. 48-76, 2008. Disponível em: <http://www.aquinate.net/revista/edicao_atual/Artigos/07/Artigo\%204Gonzalez.pdf>. Acesso em: 15 out. 2013. 
HERVADA, Javier. Lições Propedêuticas de Filosofia do Direito. Trad. de Elza Maria Gasparotto. São Paulo: Martins Fontes, 2008.

HUME, David. Tratado da natureza humana. Uma tentativa de introduzir o método experimental de raciocínio nos assuntos morais. Trad. de Déborah Danowski. 2 ed. São Paulo: Editora UNESP, 2009.

LLANO, Alejandro. Gnoseología Realista. Trad. de Fernando Marquezini. São Paulo: Instituto Brasileiro de Filosofia e Ciência "Raimundo Lúlio", 2004.

LOMBO, José Angel. La Persona en Tomás de Aquino. Un estudio Histórico y sistemático. Dissertationes. Pontificia Università Della Santa Croce. Facultà di Filosofia. Roma, Ediciones Apollinare Studi, 2001.

LOMBO, José Angel. La Persona y su Naturaleza: Tomás de Aquino y Leonardo Polo. Revistas e Series UN. Anuario Filosófico, Pamplona, n. 29, p. 721-739, 1996.

MASSMANN, Diogo Fernando. O problema da consciência: abordagem neurocientífica do problema mente-corpo. Dissertação de Mestrado. Marília: UNESP, 2012.

MELENDO, Tomás. Metafísica da realidade. As relações entre filosofia e vida. Tradução de João Roberto Costa e Silva. São Paulo: Instituto Brasileiro de Filosofia e Ciência "Raimundo Lúlio", 2002.

OLIVEIRA, Cláudia Maria Rocha de. Metafísica e ética: A filosofia da pessoa em Henrique Vaz como resposta ao niilismo contemporâneo. São Paulo: Edições Loyola, 2013.

OLIVEIRA, Juliano de Almeida. Presença de Tomás de Aquino no pensamento de H. C. de Lima Vaz. Revista Eletrônica Aquinate, Niterói, no 20, p. 11-27, 2013. Disponível em: 
<http://www.aquinate.net/revista/edicao_atual/Artigos/20/C_Artigo_20_2_pp_11-27.pdf>. Acesso em: 18 jun. 2015.

PETRÔNIO, Rodolfo. Filosofia da Natureza e Ciência. Nova perspectiva e complementaridade. Tese de doutorado. Rio de Janeiro: PUC-Rio, 2008.

Werner Heisenberg e a Platonização da Ciência. Revista Eletrônica Aquinate, Niterói, no 16, p. 241-244, 2011. Disponível em:

$<$ http://www.aquinate.net/revista/caleidoscopio/Ciencia-e-fe/16/Ciencia/M.Ciencia.16.pp.241244.pdf>. Acesso em 28 set. 2015.

PIRES, Celestino. Logos. Enciclopédia Luso-Brasileira de Filosofia. Vol. I. Termo: “Analogia”. Lisboa, Editora Verbo, 1989.

POLO, Leonardo. Quién es el hombre. Un espíritu en el tempo. 5 ed. Madrid: Ediciones RIALP, S.A., 2003.

REALE, Giovanni. Aristóteles. Metafísica. Ensaio introdutório, texto grego com tradução e comentário de Giovanni Reale. Volume II. Trad. de Marcelo Perine. 2 ed. São Paulo, Edições Loyola, 2005.

REIS, Matheus Batista dos. Sobre o problema da identidade pessoal: David Hume e seus críticos. Dissertação de Mestrado. Belo Horizonte: UFMG, 2010.

SANTACRUZ, Victor Sanz. Historia de la Filosofia Moderna. Pamplona: EUNSA, 1991.

SCARRE, Geoffrey. What Was Hume's Worry about Personal Identity? Analysis, Vol. 43, No. 4. Oxford University Press. (Oct., 1983). 
SELLÉS, Juan Fernando. Antropología de la Intimidad. Libertad, sentido único y amor personal. Madrid: Ediciones RIALP, 2013.

SMITH, Wolfgang. A praga do cientificismo. Tradução de Murilo Resende Ferreira.

Original: The plague of scientistic belief. Homiletic and Pastoral Review. Ignatius Press, San Francisco, 2000. Disponível em: < http://cientificismo.pen.io/>. Acesso em: 31 maio. 2015.

Ciência e Mito: com uma resposta a O Grande Projeto de Stephen Hawking. Tradução de Pedro Cava. Campinas: Vide Editorial, 2014.

STORK, Ricardo Yepes. Fundamentos de Antropologia. Um ideal de excelência humana. Trad. de Patricia Carol Dwyer. São Paulo: Instituto Brasileiro de Filosofia e Ciência "Raimundo Lúlio", 2005.

La persona y su intimidad. Cuadernos de Anuario Filosofico. $\mathrm{N}^{\mathrm{o}}$ 48. Pamplona: Serie Universitaria (Edição a cargo de Javier Aranguren), 1997.

TOMÁS DE AQUINO. O ente e a essência. Trad. de D. Odilão Moura, OSB. Rio de Janeiro: Editora Presença, 1981.

Suma Teológica. Trad. de Carlos Josaphat P. de Oliveira (coordenação-geral). Volume I. 2 ed. São Paulo: Edições Loyola, 2001.

VAZ, Henrique Claudio de Lima. Antropologia Filosófica. Volume. I. 4 ed. Corrigida. São Paulo: Edições Loyola, 1998.

Antropologia Filosófica. Volume. I. 9 ed. São Paulo:

Edições Loyola, 2009. 
Antropologia Filosófica. Volume II. 2 ed. São Paulo:

Edições Loyola, 1992.

WITTGENSTEIN, Ludwig. Investigações Filosóficas. Trad. de José Carlos Bruni. Coleção: Os Pensadores. São Paulo: Editora Abril Cultural, 1975.

Tractatus Logico-Philosophicus. Trad. de José Arthur

Giannotti. São Paulo: Editora da Universidade de São Paulo, 1968. 